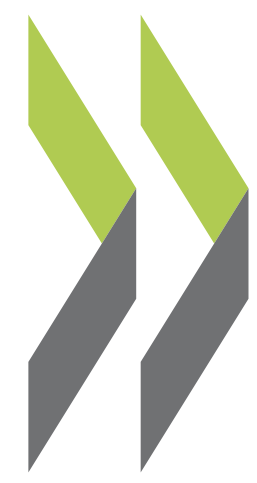

OECD Economics Department Working Papers No. 1342

The Distributional Impact of Structural Reforms

Orsetta Causa, Mikkel Hermansen, Nicolas Ruiz 
Organisation de Coopération et de Développement Économiques

Organisation for Economic Co-operation and Development

17-Nov-2016

ECONOMICS DEPARTMENT

English - Or. English

THE DISTRIBUTIONAL IMPACT OF STRUCTURAL REFORMS

ECONOMICS DEPARTMENT WORKING PAPERS No. 1342

By Orsetta Causa, Mikkel Hermansen and Nicolas Ruiz

OECD Working Papers should not be reported as representing the official views of the OECD or of its member countries. The opinions expressed and arguments employed are those of the author(s).

Authorised for publication by Christian Kastrop, Director, Policy Studies Branch, Economics Department.

All Economics Department Working Papers are available at www.oecd.org/eco/workingpapers

Complete document available on OLIS in its original format

This document and any map included herein are without prejudice to the status of or sovereignty over any territory, to the delimitation of international frontiers and boundaries and to the name of any territory, city or area. 
OECD Working Papers should not be reported as representing the official views of the OECD or of its member countries. The opinions expressed and arguments employed are those of the author(s).

Working Papers describe preliminary results or research in progress by the author(s) and are published to stimulate discussion on a broad range of issues on which the OECD works.

Comments on Working Papers are welcomed, and may be sent to OECD Economics Department, 2 rue André-Pascal, 75775 Paris Cedex 16, France, or by e-mail to eco.contact@oecd.org.

All Economics Department Working Papers are available at. www.oecd.org/eco/workingpapers.

This document and any map included herein are without prejudice to the status of or sovereignty over any territory, to the delimitation of international frontiers and boundaries and to the name of any territory, city or area.

The statistical data for Israel are supplied by and under the responsibility of the relevant Israeli authorities. The use of such data by the OECD is without prejudice to the status of the Golan Heights, East Jerusalem and Israeli settlements in the West Bank under the terms of international law.

Latvia was not an OECD Member at the time of preparation of this publication. Accordingly, Latvia does not appear in the list of OECD Members and is not included in the zone aggregates.

\section{(C) OECD (2016)}

You can copy, download or print OECD content for your own use, and you can include excerpts from OECD publications, databases and multimedia products in your own documents, presentations, blogs, websites and teaching materials, provided that suitable acknowledgment of OECD as source and copyright owner is given. All requests for commercial use and translation rights should be submitted to rights@oecd.org 


\section{ABSTRACT/RÉSUMÉ \\ The Distributional Impact of Structural Reforms}

In a majority of OECD countries, GDP growth over the past three decades has been associated with growing income disparities. To shed some lights on the potential sources of trade-offs between growth and equity, this paper investigates the long-run impact of structural reforms on household incomes across the distribution, hence on income inequality. The paper builds on a macro-micro approach by combining recent macro-level estimates of the impact of structural reforms on macroeconomic growth with microlevel estimates of the impact of structural reforms on household incomes across the income distribution. It considers the sources of macroeconomic growth, by decomposing growth in GDP per capita into growth in labour utilisation and labour productivity. This allows for shedding light on the mechanisms through which growth and its drivers, including policy drivers, benefit household incomes at different points of the income distribution. Most structural reforms are found to have little impact on income inequality when the latter is assessed through measures that emphasise the middle class. By contrast, a higher number of structural reforms, in particular social protection reforms, are found to have an impact on income inequality and thus may raise tradeoffs and synergies between growth equity objectives when inequality is assessed through measures that emphasise relatively more incomes among the poor. This corresponds to higher degrees of inequality aversion.

JEL codes: O15; D31; E61

Keywords: growth, inequality, structural policies

$* * * * * * * * * * * * * * * * * * * * * * * * * * *$

\section{L'impact distributionnel des politiques structurelles}

Dans la majorité des pays de l'OCDE la croissance du PIB au cours des trois dernières décennies a été associée à des disparités croissantes de revenus. Afin de comprendre le lien entre ces deux phénomènes, cet article étudie l'impact de long terme des réformes structurelles sur la distribution des revenus. Le cadre empirique proposé est une approche macro-micro, combinant des estimations récentes au niveau macro de l'impact des réformes structurelles sur la croissance macroéconomique, avec des estimations au niveau micro de l'impact des réformes structurelles sur les revenus des ménages le long de la distribution. Les sources de la croissance sont aussi décomposées, entre travail et productivité, afin d'illustrer par quels mécanismes la croissance et les politiques structurelles bénéficient aux ménages. La plupart des réformes structurelles se trouvent avoir peu d'impact sur les inégalités de revenu lorsque le focus est sur la classe moyenne. En revanche, un nombre plus élevé de réformes structurelles, en particulier les réformes de la protection sociale, se trouvent avoir un impact significatif lorsque le focus est sur les segments les plus pauvres de la distribution.

Codes JEL: O15; D31; E61

Mots clés: croissance, inégalité, politiques structurelles 


\section{TABLE OF CONTENTS}

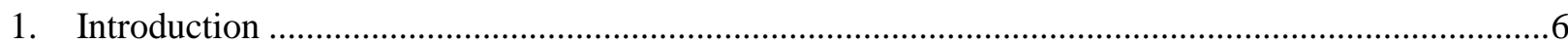

2. A combined macro-micro framework to growth and income distribution ....................................... 9

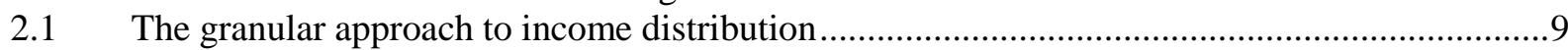

2.2 The distributional effects of growth and its Sources: baseline estimates ................................12

2.3 The distributional effects of structural reforms: a combined macro-micro approach ...............16

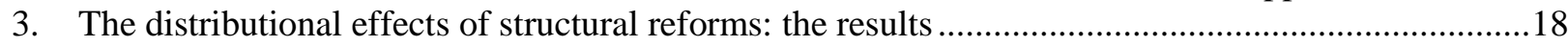

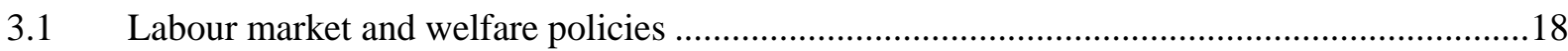

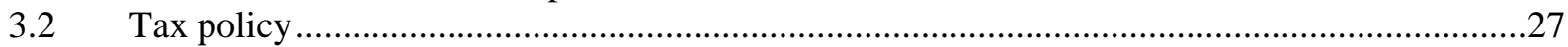

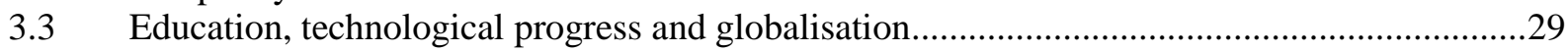

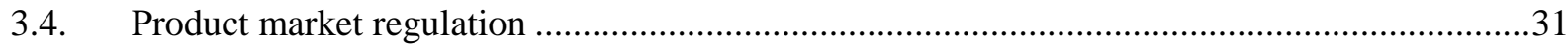

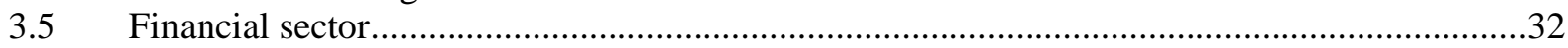

4. Policy synergies and trade-offs between growth and equity ..........................................................33

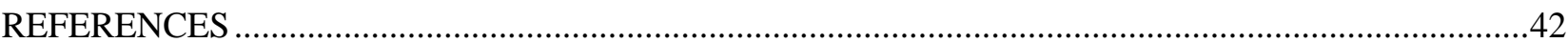

APPENDIX: ADDITIONAL MATERIAL ON THE EMPIRICAL FRAMEWORK .................................45

A.1. Defining total household income policy effects in a combined macro-micro approach ...........45

Step 1: Micro policy effects: estimating policy effects across the income distribution ...........................45

Step 2: Macro policy effects: building on empirical estimates from companion studies .......................46

Step 3: Combining micro and macro policy estimates to obtain total household income effects ..........49

Testing the significance of combined macro-micro estimates ….......................................................50

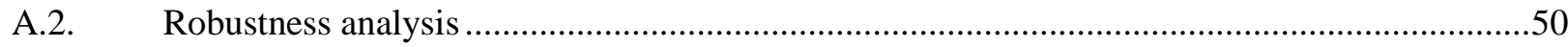

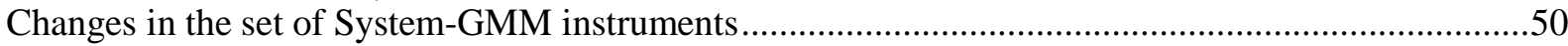

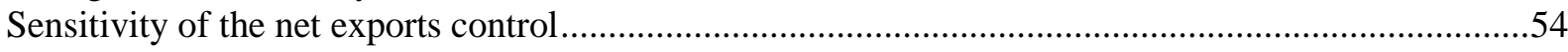

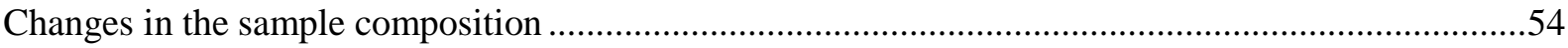

A.3. Simulating growth and inequality effects of policy reforms ...............................................57

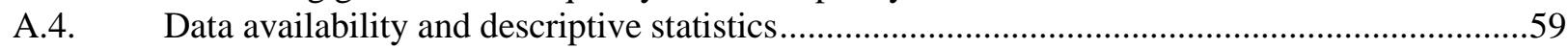

\section{Tables}

Table 1. Policy synergies and trade-offs between growth and equity: illustrative reform scenarios

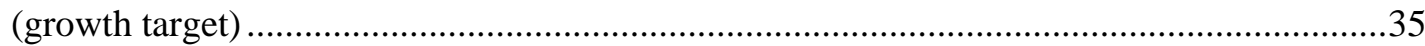

Table 2. Policy synergies and trade-offs between growth and equity: illustrative reform scenarios

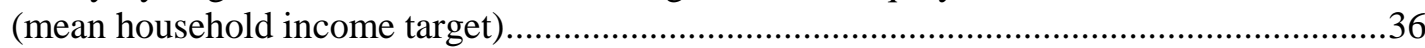

Table 3. Policy synergies and trade-offs between growth and equity: illustrative reform scenarios

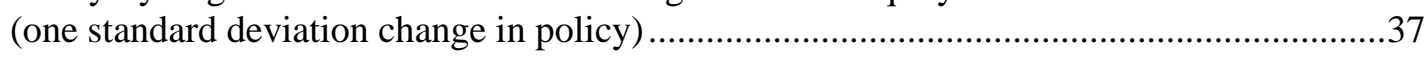

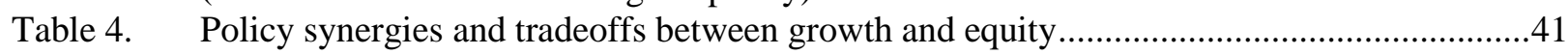

Table A1. Macroeconomic estimates of policy effects on labour productivity ....................................46

Table A2. Macroeconomic estimates of policy effects on the employment rate..................................47

Table A3. Applied adjustments of macroeconomic estimates............................................................47

Table A4. Alternative small set of System-GMM instruments .......................................................52

Table A5. Alternative large set of System-GMM instruments..........................................................53

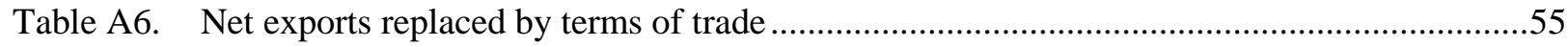

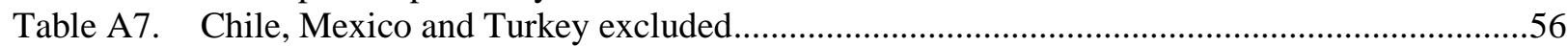

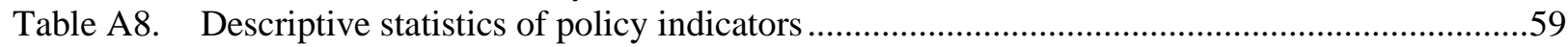

Table A9. Country and time coverage in the empirical analysis .........................................................60 


\section{Figures}

Figure 1. Atkinson index for income inequality ...........................................................................12

Figure 2. The distributional effects of growth and its sources: baseline estimates .............................15

Figure 3. The combined macro-micro approach .......................................................................... 16

Figure 4. Effects of a reduction in UB average gross replacement rates on household disposable incomes 18

Figure 5. Effects of a reduction in UB net replacement rates for long-term unemployed on household

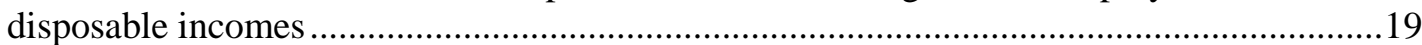

Figure 6. Effects of an increase in ALMP spending on unemployed on household disposable incomes....20

Figure 7. Effects of an increase in the legal pension age on household disposable incomes...............21

Figure 8. Effects of an increase in family in-kind benefits on household disposable incomes.............22

Figure 9. Effects of a reduction in EPL for regular contracts on household disposable incomes.........23

Figure 10. Effects of a reduction in union density on household disposable incomes...........................25

Figure 11. Effects of a reduction in excess coverage of collective agreements on household disposable

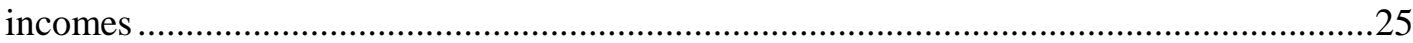

Figure 12. Effects of an increase in the degree of coordination of wage-setting on household

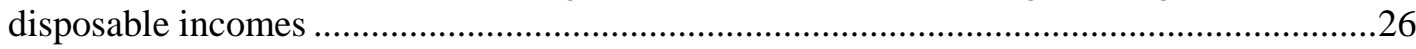

Figure 13. Effects of a reduction in minimum relative to median wage on household disposable

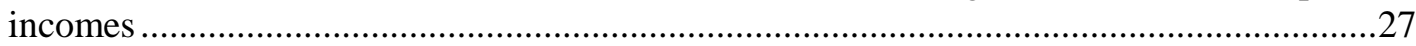

Figure 14. Effects of a reduction in the labour tax wedge for one-earner couples on household

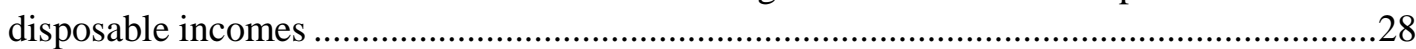

Figure 15. Effects of a tax revenue-neutral reduction in the labour tax wedge for one-earner couples on household disposable incomes

Figure 16. Effects of an increase in government spending on education on household disposable

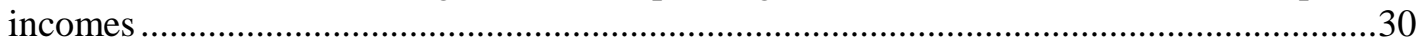

Figure 17. Effects of an increase in general spending on R\&D on household disposable incomes........31

Figure 18. Effects of an increase in patent applications on household disposable incomes ..................31

Figure 19. Effects of a reduction in regulation in network industries on household disposable incomes ....32

Figure 20. Effects of an increase in value added of finance on household disposable incomes ............33

Figure 21. Pro-growth policy reforms and household disposable income across the distribution ..........40

\section{Boxes}

Box 1. Baseline specification of the distributional incidence of growth and its sub-components .14 Box 2. Assessing the impact of structural reforms on income distribution: a combined macro-micro framework 


\title{
THE DISTRIBUTIONAL IMPACT OF STRUCTURAL REFORMS
}

\author{
Orsetta Causa, Mikkel Hermansen and Nicolas Ruiz ${ }^{1}$
}

\section{Introduction}

1. Structural reforms are regularly assessed based on their ability to improve long-term GDP per capita, a widely-used measure of living standards and a key headline indicator of economic performance, which in turn is decomposed into labour productivity and labour utilisation (OECD, 2015a). Part of the motivation for the emphasis given to economic growth relies on the assumption that higher GDP per capita is systematically associated with rising living standards for the vast majority of citizens. This view is increasingly being challenged.

2. The dispersion of disposable incomes (i.e. after taxes and social transfers) has been steadily on the rise during the past 30 years (Atkinson, 2015; OECD, 2008; 2011a; 2011b; 2015b). According to the Gini coefficient, market income inequality (before taxes and transfers) increased as much in the first three years of the crisis as it did in the twelve years before (see OECD, 2015b), putting pressures on transfer systems and public finances. Moreover, while a certain degree of income and wealth inequality is a characteristic of market economies, beyond a certain point, and not least during an economic crisis, growing income inequalities can undermine the foundations of market economies, for example if they eventually lead to inequalities of opportunity, weakening incentives to invest in knowledge. The worrying evolution of income inequality in many countries suggests that distributional considerations need to be more systematically taken into account in policy making. This is made possible by the notable progress achieved over the recent past in measuring income inequality, hence in the possibility of assessing its policy drivers.

3. In this context, the purpose of this paper is to provide new empirical evidence on the effects of structural policies on household income across the distribution, hence on income inequality. ${ }^{2,3}$ It extends and completes an earlier paper that provided preliminary evidence on policy synergies and trade-offs between growth and equity objectives (Causa et al., 2015). ${ }^{4}$ That paper investigated the extent to which structural policies have differential long-run impacts on GDP per capita and household incomes at different

1. The authors are members of the Economics Department of the OECD. They would like to thank Balázs Égert and Peter Gal (both with the OECD, Economics Department) for producing additional macroeconomic estimates of policy reforms for this paper. They also thank colleagues from the Economics Department, Alain de Serres, Alberto Gonzalez Pandiella, Christian Kastrop, Catherine L. Mann, Rory O'Farrell, Jean-Luc Schneider and Jan Strasky, Stefano Scarpetta and colleagues from the Directorate for Employment, Labour and Social Affairs, colleagues from the Statistics Directorate and participants in the Working Party No. 1 of the Economic Policy Committee for useful comments and suggestions. They also thank Caroline Abettan for editorial assistance.

2. Throughout the paper, more equity is to be interpreted as less inequality in income distribution and does not imply any judgement about the intrinsic value of a more equal distribution.

3. In this paper, inequality is examined from a static perspective. While ultimately a comprehensive assessment would need covering inequality in life-cycle perspective as well as dynamic inequality, hence intra-generational mobility as well as inter-generational mobility, such analysis is beyond the scope of this study, particularly reflecting major data limitations. For cross-country empirical evidence on intergenerational social mobility in OECD countries, see Causa and Johansson (2009).

4. It also builds on earlier studies on the topic such as OECD (2011a). 
points of the distribution corresponding to different income groups. It introduced a new granular approach to income distribution, which allows for summarising the level of income by placing different weights on different portions of the distribution. Taking average income as the benchmark point, the analysis focused on the lower-half of the income distribution, i.e. moving gradually from median (middle class) to bottom incomes (the poor).

4. The current paper enhances this analysis and goes beyond in three main respects. First, it considers the income distribution in its entirety, from bottom (the poor) to top (the rich). ${ }^{5}$ Second, it builds on a combined macro-micro approach by combining recent external macro-level estimates of the impact of structural reforms on macroeconomic growth from Gal and Theising (2015) and Egert (2016) ${ }^{6}$ with microlevel estimates of the impact of structural reforms on household incomes across the income distribution. Third, it considers the sources of macroeconomic growth, by decomposing growth in GDP per capita into growth in labour utilisation (measured by the employment rate) and labour productivity (measured by GDP per worker). This allows for shedding light on the mechanisms through which growth and its drivers, including policy drivers, benefit household incomes at different points of the income distribution. As a result of these considerations, the paper aims at delivering a more complete assessment of policy synergies and trade-offs between growth and equity objectives. Main findings can be summarised as follows:

- Growing income disparities experienced by many OECD countries over the last three decades have raised concerns about the distribution of the growth dividends.

- Although growth has been associated with rising inequality, there is no evidence that GDP growth triggered rising inequality, once controlling for other factors on average across OECD countries over the period under consideration. This would tend to suggest that factors other than GDP growth itself have been driving widening income gaps between rich and poor households.

- The breakdown of growth into its main sources, i.e. productivity and labour utilisation, sheds light on the mechanisms of the growth and inequality nexus:

- The evidence suggests that productivity growth is not by itself inclusive: aggregate labour productivity gains benefits significantly more rich households and those in the upper-middle class than poor households and those in the lower-middle class.

- Labour utilisation growth is by contrast inclusive: the evidence provided indicates that higher aggregate employment benefits disproportionately households in the bottom half of the income distribution.

- Ensuring that productivity gains foster job creation is thus crucial to make growth more inclusive.

- The main findings on the effects of structural reforms on the distribution on household disposable income can be summarised as follows, on the basis of OECD cross-country evidence over the last 30 years:

- Most structural reforms have little impact on income inequality when the latter is assessed through measures that emphasise the middle class.

5. The well-known issue of top incomes under-coverage in household surveys precludes delivering an accurate assessment of incomes at the very top of the distribution in this paper (see Ruiz and Woloszko, 2015). Further work is therefore warranted to uncover the links between structural policies and top incomes.

6. Gal and Thesing (2015) estimates are relied upon for the impact of pro-growth reforms on labour utilization and Egert (2016) for the impact on labour productivity. 
- By contrast, a higher number of structural reforms have an impact on income inequality and thus may raise tradeoffs and synergies between growth equity objectives when inequality is assessed through measures that emphasise relatively more incomes among the poor. This corresponds to higher degrees of inequality aversion.

- Social protection and labour market reforms are the sources of most of the trade-offs between growth and equity objectives. Reductions in the generosity of unemployment benefits and social assistance are found to leave poor households behind. These findings suggest that raising employment while making it more inclusive requires well-targeted active labour market policies (ALMPs) with a view to enhancing employability among the low-skilled, the long-term unemployed and discouraged jobseekers.

- Reforms of wage-setting institutions, including those affecting the extent of unionisation, may be good or bad for equity, depending on the reform design. Limiting the automatic extension of collective agreements and increasing wage bargaining coordination are found to boost labour market performance and inclusiveness. Moderate minimum wage reductions are not found to trigger a rise in disposable income inequality if they allow for encouraging employment creation among the low-skilled, and this effect may counteract potential increases in wage dispersion. By contrast, the trend decline in the rate of unionisation experienced by many OECD countries over the last three decades is found to have contributed to the rise in income inequality.

- Reductions in labour taxation may raise a trade-off between growth and equity objectives, even if they generate aggregate employment gains. Reforms in this area can nevertheless achieve both employment and equity objectives, for instance by targeting tax reductions at low-wage earners or by increasing earned-income tax credits.

- Easing barriers to firm entry and competition in product markets produces strong macroeconomic gains without raising trade-offs between efficiency and equity objectives since associated income gains accrue to households at large and are fairly equally shared.

- Increasing public spending on education, in particular on childcare and early childhood education, boosts growth and at the same time reduces income inequality, for instance by enhancing the labour market inclusion of women.

5. The rest of the paper is structured as follows. Section 2 lays-out the analytical framework and the starting point of the analysis: it assesses the distributional effects of growth along its sources (i.e. labour productivity and labour utilisation). Section 3 follows this approach to deliver new evidence on the impact of structural reforms on household disposable incomes across the income distribution. The focus is on growth-enhancing policy drivers, reforms and institutions that have been found to boost GDP per capita through various channels. Other drivers such as up-skilling, globalisation and technological change are covered only succinctly. ${ }^{7}$ Section 4 wraps-up the empirical findings by delivering simulations of the effects of selected growth-enhancing policy reforms on income inequality.

7. This topic has been tackled by numerous inequality studies, such as e.g. Braconier and Ruiz-Valenzuela, (2014), Ostry et al. (2014) and Chapter 2 of OECD (2011a). 


\section{A combined macro-micro framework to growth and income distribution}

\subsection{The granular approach to income distribution}

6. The analytical framework of this paper has been originally developed in Causa et al. (2015) following Foster and Szekeley (2008). ${ }^{8}$ It is based on Atkinson (1970) framework for inequality and welfare analysis, which encompasses mean income and the income distribution within a simple unified measure - the general means approach. General means are flexible, distribution-sensitive income measures based on the use of different weights for different parts of the income distribution; broadly corresponding to different income groups such as the poor, the rich and the middle class. ${ }^{9}$ General means take into account the entire income distribution, emphasising lower or higher incomes depending on the value taken by a specific parameter $\alpha$, often referred to as the order of the general mean. This avoids the need to set arbitrary thresholds that give full weight to some parts of the distribution and no weight to the remaining parts (as is often the case in poverty measurement or deciles analysis for example). The benchmark case in which $\alpha$ equals 1 coincides with mean income.

7. General means allow for producing a comprehensive picture of the income distribution through the use of a wide range of $\alpha$ s which explicitly reflect different weights applied to different points of the income distribution or different income groups. The choice of $\alpha$ is thus ultimately related to how the general mean is connected to different parts of the income distribution: as $\alpha$ approaches minus infinity, the general mean converges to the lowest observed income in society. The order of $\alpha$ can therefore be taken to represent the level of inequality aversion. For $\alpha=1$ the general mean corresponds to the arithmetic mean (i.e. mean income). As $\alpha$ decreases below 1, preferences become more egalitarian, placing relatively more weight on the poor and less weight on the rich than mean income. Choosing how to weight different segments of the distribution or, equivalently, the degree of inequality aversion is not straightforward, not least because inequality aversions are not observable across countries. However, the Atkinson framework is a transparent and flexible tool that makes it possible to span several normative views in the area of inequality and welfare.

8. In order to provide some intuition behind the interpretation of $\alpha$ and the role of inequality aversion in the general mean framework, Hermansen et al. (2016) calculate the implicit distributional weights implied by general means for various $\alpha$ s, defined as the elasticities of the general mean with respect to average income in each decile. This shows for instance that across OECD countries, when $\alpha=-$ 4 , the weight of the first decile is around 0.8, that of the second decile is around 0.1 and that of the fifth (and above) decile is almost 0 . At the other extreme, when $\alpha=6$, the weight of the last decile is around 0.9 while that that of the fifth (and below) decile is almost 0. In this paper, the case of $\alpha=-4$ is therefore referred to as the case where the emphasis of the general mean is on incomes among the poor, while the case $\alpha=6$ is referred to as the case where the emphasis of the general mean is on incomes among the rich.

8. See also Foster et al. (2013) for the practical implementation of general means in the World Bank inequality and poverty assessment.

9. For an income distribution $\mathrm{x}=(\mathrm{x} 1, \ldots, \mathrm{xN})$, the general mean of order $\alpha, \mu(\mathrm{x}, \alpha)$, is defined as:

$$
\begin{aligned}
\mu(x, \alpha) & =\left(\frac{1}{N} \sum_{i=1}^{N} x_{i}^{\alpha}\right)^{\frac{1}{\alpha}} \text { if } \alpha \neq 0 \\
& =\prod_{i=1}^{N} x_{i}^{\frac{1}{N}} \text { if } \alpha=0
\end{aligned}
$$

The case where $\alpha=1$ corresponds to the arithmetic mean of the distribution. 


\section{ECO/WKP(2016)66}

The intermediate cases of $\alpha=-1$ (corresponding to weighting relatively more the bottom 3 deciles) and $\alpha=$ 3 (corresponding to weighting relatively more the top 3 deciles) are referred to as the cases where the emphasis is on incomes among the lower-middle class and the upper-middle class, respectively. ${ }^{10}$

9. The general means approach can then naturally be used as a direct input to build synthetic measures of inequality known as Atkinson inequality measures (Atkinson, 1970). These measures are of a general form in the sense that they can be adjusted to different levels of inequality aversion in a transparent way. The intuition behind Atkinson inequality measures is very simple: for a given level of inequality aversion governed by the parameter $\alpha$ (lower than 1) of a general mean, ${ }^{11}$ inequality corresponds to the difference between mean income (i.e. the general mean of order 1) and the general mean of order $\alpha$. This shortfall varies between 0 and 1 and represents the loss of income induced by an unequal distribution of income. For a given distribution of income, the lower the value of $\alpha$, the higher the level of inequality aversion and the higher the resulting level of inequality according to the Atkinson measure. Setting $\alpha$ close to 0.5 produces a ranking of income distributions generally similar to the one obtained by the Gini because this is empirically tantamount to focusing on the middle of the income distribution. Lower values of $\alpha$ correspond to higher levels of inequality aversion and progressively emphasise the bottom of the income distribution, e.g. $\alpha$ around -4 emphasises the poor as illustrated and discussed before. Associated Atkinson measures of inequality then come closer to the Rawlsian welfare criteria.

10. The central income concept used throughout the analysis is that of household disposable income, as this is the best proxy of households' economic resources defined by internationally agreed standards and computable across the income distribution. ${ }^{12}$ Household disposable income broadly builds on the following pillars:

- Income concept: disposable income encompasses all income sources, hence it includes net transfers from government (cash transfers net of direct taxes paid by households) in addition to market income, which covers both labour income (wages, salaries and self-employment income) and income derived from capital.

- Deflator: Nominal values of disposable income are deflated with the consumer price index, a standard practice. However, as price indices differentiated by population groups are not available for most countries, this entails the implicit assumption of a single representative consumption structure across the income distribution,

- Unit of observation: income is measured at the household as opposed to individual level and takes into account economies of scale in consumption within households. ${ }^{13}$

10. The analysis suggests that such implicit weights are very similar across OECD countries, despite the large cross-country differences in income distributions; however some difference in implied weights is observed for extreme $\alpha$ values between advanced and emerging OECD economies as those countries exhibit large income dispersion relative to the average OECD country. Overall the analysis allows for concluding that relying a common same set of benchmark cases ( $\alpha$ s) for the purpose of cross-country empirical work is an acceptable practice, but also suggests some caution in interpreting the results for countries such as Chile, Mexico and Turkey.

11. The link between Atkinson inequality measures and general means is developed in more detail in the companion to this paper (Hermansen et al., 2016).

12. Ideally one would need to rely on the most comprehensive measure: household adjusted disposable income, taking into account in-kind transfers such as education and health care but this measure is not available on a time-series basis and is difficult to use for international comparisons (see below on data limitations). See OECD (2008) for an analysis on the redistributive impact of in-kind transfers.

13. As standard in inequality analysis, income measures are defined on an "equivalised" (or "per consumption unit") basis. The notion of "equivalisation" implies that the income attributed to each person in a household 
- Scope of the reference population: income is measured for total population (as covered in surveybased data) as opposed to sub-groups such as in particular the working or working-age population.

In the rest of this paper, income will refer to disposable income unless otherwise specified.

11. The empirical analysis relies on the OECD Income Distribution (IDD) database, where an attempt is made to achieve the best possible comparability across countries and over time. Despite the high quality of the data, especially from a cross-country comparative perspective, some caveats need being borne in mind, such as the reliance on a cash-based income concept, which implies the exclusion of several non-cash components such as in-kind public transfers and income for owner-occupied housing; as well as the exclusion of indirect taxes in the measure of taxes paid by households. ${ }^{14}$ As a result, the data do not allow for identifying the effects on household disposable incomes across the distribution of e.g. reforms shifting taxation from income to consumption. ${ }^{15}$

Figure 1 presents levels and changes of household disposable income inequality on the basis of the Atkinson framework applied to the IDD data, for OECD countries since the mid-90s. This allows for having an idea on the magnitude of associated inequality measures and therefore for better interpreting the subsequent results. ${ }^{16}$ The Atkinson inequality index is computed for two benchmark cases of inequality aversion (as governed by the parameter $\alpha$ ): 1) weak inequality aversion, i.e. emphasis on the middle class $(\alpha=0.5)$ - equivalent to the assessment based on the Gini coefficient, and 2) strong inequality aversion, i.e. emphasis on the "poor" $(\alpha=-4)$. Under a relatively weak inequality aversion, the Atkinson measure delivers approximately the same country ranking as the Gini coefficient, while under a stronger inequality aversion, differences in countries relative positions occur compared to the Gini coefficient, as documented in the companion to this paper (Hermansen et al., 2016).

reflects income sharing within the household and adjusts for household needs. It is assumed that these needs increase with household size, but less than proportionally. A number of "scales" exist for such adjustment. In this analysis, total household income is divided by the square root of household size.

14. A more comprehensive discussion on the data is provided in the companion to this paper (Hermansen et al., 2016).

15. The impacts of such reforms could be at least partially captured through changes in the consumer price index. However, as stated above the lack of price index differentiated across the population precludes the possibility of capturing any distributional effects.

16. The Atkinson measures have been rescaled to vary between 0 and 100 . 
Figure 1. Atkinson index for income inequality

A. Weak inequality aversion $(\alpha=0.5)$

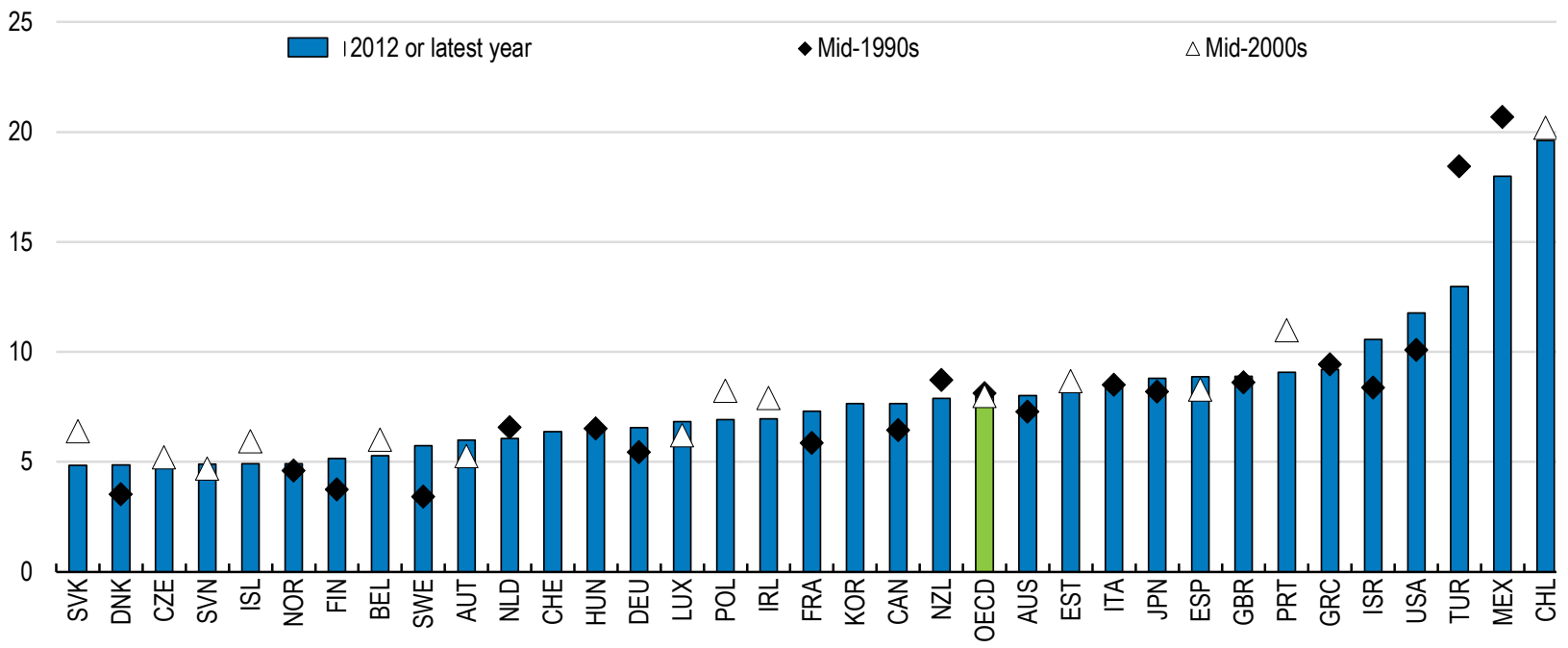

B. Strong inequality aversion $(\alpha=-4)$

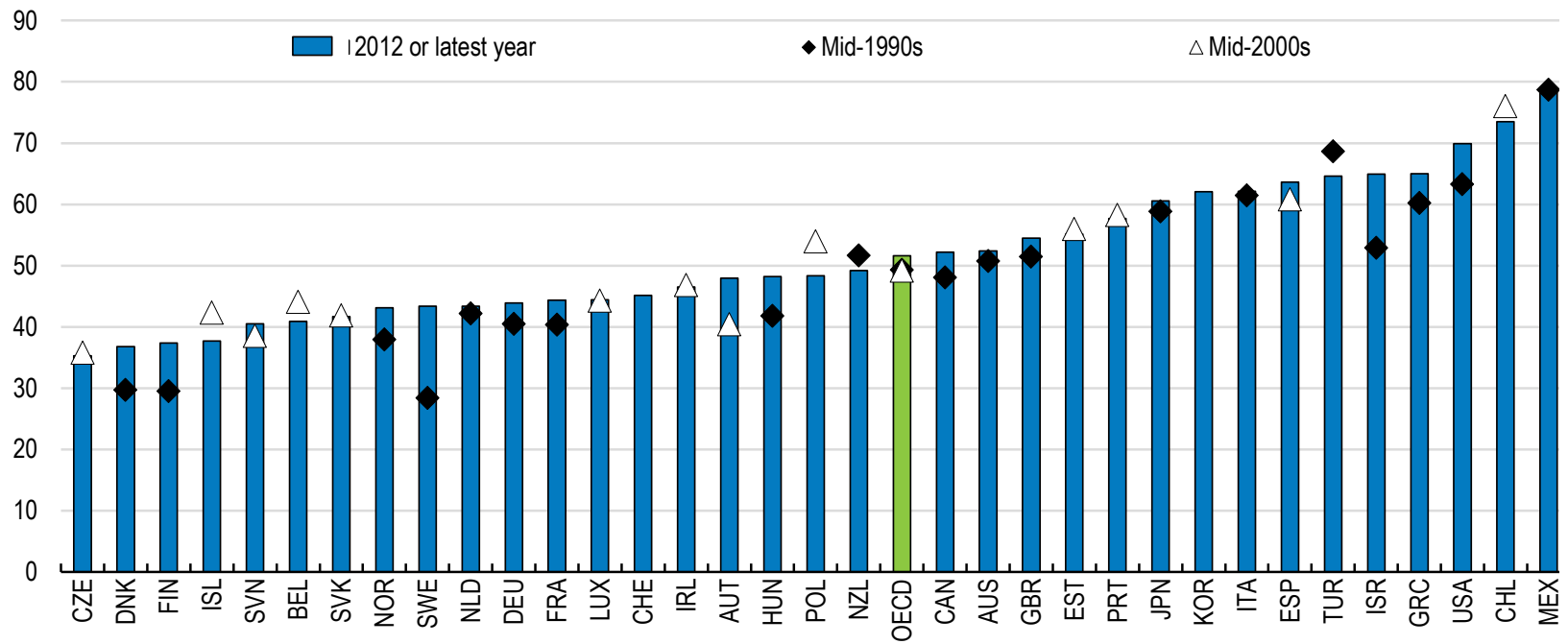

Note: The Atkinson inequality index varies from 0 to 100 with higher values corresponding to higher levels of inequality. By construction it varies from 0 to 1 but has been rescaled by 100 here.

Source: OECD Income Distribution Database.

\subsection{The distributional effects of growth and its Sources: baseline estimates}

12. As a baseline step, the analysis starts by revisiting the link between growth and household incomes across the distribution (Box 1). This sets the stage for the analysis of the link between growthenhancing reforms and household incomes across the distribution, that is, the distributional effects of growth-enhancing reforms. Growth is likely to have differential effects on different income groups, ${ }^{17}$ and

17. See Voitchovsky (2005) for a detailed discussion. 
this is captured though the general means approach. The baseline estimates presented in this paper extend Causa et al. (2015) in two main ways:

- By addressing potential endogeneity issues due to reverse causality between growth, household incomes and income inequality. This is achieved by using System GMM estimation techniques, as presented and illustrated in detail in the companion to this paper (Hermansen et al., 2016).

- By identifying the differential impact of the sources of growth on household incomes and income inequality. This is achieved by splitting GDP per capita into labour productivity and labour utilisation and analysing the differential effect of these components on household incomes across the distribution, moving progressively from poor to rich households.

13. The sample covers OECD countries for the period going from the mid-80s to around 2012, but with varying time coverage across countries. ${ }^{18}$ The main findings can be summarised as follows:

- There is no evidence that GDP growth triggered the rise in inequality, once controlling for other factors. On average across OECD countries, GDP growth over the last three decades has lifted household disposable incomes across the distribution. This assessment derives from visualising the GDP growth incidence curve (Figure 2, Panel A). This curve is broadly flat at the unitary GDP per capita elasticity of household disposable income. ${ }^{19}$ However, associated cross-country estimates inevitably encompass cross-country differences in the distributional incidence of growth. Even from a purely descriptive perspective, OECD countries experienced heterogeneous developments in this respect (Hermansen et al. 2016).

- The finding that GDP growth has benefited household disposable incomes at large results from the differential effects of the sources of growth, namely labour productivity and labour utilisation, on income distribution:

- Labour productivity growth has benefitted relatively more to rich households and households in the upper middle class (corresponding to values of $\alpha$ roughly above 1), while associated growth dividends were somewhat lower among poor households (e.g. $\alpha=$ -4) (Figure 2, Panel B). This implies that productivity growth has been slightly disequalising. ${ }^{20}$

- Labour utilisation growth has benefitted disproportionally to poor households and households in the middle class (corresponding to values of $\alpha$ roughly around 0 ), while associated growth dividends were insignificant for rich households (e.g. $\alpha>4$ ) (Figure 1, Panel C). This implies that labour utilisation has allowed for lifting the material conditions of the poor people and that it has been equalising.

18. See Appendix for details on cross-country time series coverage.

19. Although the estimated value of the GDP elasticity for mean household income is equal to 1.2, a formal test confirms that it is not statistically significantly different from 1 at the $5 \%$ level, in line with theoretical priors and previous work (Causa et al., 2015).

20. The econometric approach (Box 1) precludes the possibility to properly assess significant statistical differences between reform effects at various portions of the income distribution. However, the profiles of the curves displayed throughout this paper can tentatively identify statistical differences between e.g. the rich and the poor. Actually, a relatively flat profile will point to identical effects across the distribution, thus no distributional impact, while a more stretched out profile will tend to characterise statistically significant differences across the distribution. 


\section{Box 1. Baseline specification of the distributional incidence of growth and its sub-components ${ }^{1}$}

The fundamental determinants of GDP, i.e. human and physical capital, labour-augmenting efficiency and population growth, are well established in growth theory and the production function framework, but there exists no such framework in the case of household incomes with an explicit consideration of its distribution. In the absence of a theoretical foundation, a natural starting point is to assume that in the long run the level of household income at each point of the distribution is mainly driven by the level of GDP per capita, which transmits to households with a lag (see Causa et al., 2015):

$$
\Delta \ln \mu_{\alpha}\left(x_{i t}\right)=\beta_{0, \alpha}-\beta_{1, \alpha} \ln \mu_{\alpha}\left(x_{i t-1}\right)+\beta_{2, \alpha} \Delta \ln G D P_{i t}+\beta_{3, \alpha} \ln G D P_{i t-1}+\beta_{4, \alpha} N X_{i t}+\gamma_{t}+\eta_{i}+\varepsilon_{i t}
$$

where periods $\mathrm{t}$ and $\mathrm{t}-1$ correspond to observations 2 years apart, $\Delta \ln \mu_{\alpha}\left(x_{i t}\right)$ is the growth in household income across the distribution (the order of the general mean a allows for uncovering different portions of the distribution, from bottom to top), $\Delta \ln G D P_{i t}$ is the growth in GDP per capita, $N X_{i t}$ is the ratio of net exports to GDP included to control for persistent gaps between household incomes and domestic output, ${ }^{2} \gamma_{t}$ denotes time controls (a linear time trend), and $\eta_{i}$ denotes country fixed effects. Due to the presence of the lagged dependent variable to account for convergence, the specification is estimated through System GMM. ${ }^{3}$ This allows for deriving a consistent estimate of the long-run elasticity of household incomes with respect to GDP per capita, given by $\varepsilon_{\mu_{\alpha}, G D P}=\beta_{3, \alpha} / \beta_{1, \alpha}$.

The impact of GDP is subsequently decomposed along its two main sub-components, labour productivity (LP) and labour utilisation (LU), expanding the previous specification as follows:

$$
\begin{aligned}
\Delta \ln \mu_{\alpha}\left(x_{i t}\right)= & \theta_{0, \alpha}-\theta_{1, \alpha} \ln \mu_{\alpha}\left(x_{i t-1}\right)+\theta_{2, \alpha} \Delta \ln L P_{i t}+\theta_{3, \alpha} \ln L P_{i t-1}+\theta_{4, \alpha} \Delta \ln L U_{i t}+\theta_{5, \alpha} \ln L U_{i t-1} \\
& +\theta_{6, \alpha} N X_{i t}+\gamma_{t}+\eta_{i}+\varepsilon_{i t}
\end{aligned}
$$

Labour productivity and labour utilisation are (as GDP) treated as endogenous variables and the equation is also estimated through System GMM. This allows for deriving consistent estimates of the long-run elasticity of household incomes across the distribution with respect to labour productivity, $\varepsilon_{\mu_{\alpha}, L P}=\theta_{3, \alpha} / \theta_{1, \alpha}$, and with respect to labour utilisation, $\varepsilon_{\mu_{\alpha}, L U}=\theta_{5, \alpha} / \theta_{1, \alpha}$.

1. See (Hermansen et al., 2016) for a full presentation of the baseline specification and econometric approach.

2. The underlying rationale is that mean household income elasticity to domestic production is more likely to deviate from 1 in more open economies under persistent external imbalances whereby households tend to consume more (deficit) or less (surplus) than their income. In addition, previous work has shown that the difference between growth in real GDP and in real mean household income is, to a large extent, driven by differences in growth of output relative to consumer prices (Causa et al., 2014; 2015). In turn, the evidence would suggest that this is, to a good extent, driven by terms-of-trade effects. Results in this paper are qualitatively unchanged if the openness variable is replaced by the current account, the terms-of-trade, or the price of consumption relative to output.

3. See Blundell and Bond (1998).

14. The conclusion from this baseline analysis is that the composition of growth is a key determinant of its incidence across the distribution. Insofar as growth is ultimately driven by labour productivity, and insofar as this is associated with rising income inequality, ensuring that growth is associated with strong job creation is crucial to make it more inclusive. These baseline findings are combined into a macro-micro approach to deliver a complete distributional assessment of labour productivity and labour utilisationenhancing reforms. 
Figure 2. The distributional effects of growth and its sources: baseline estimates

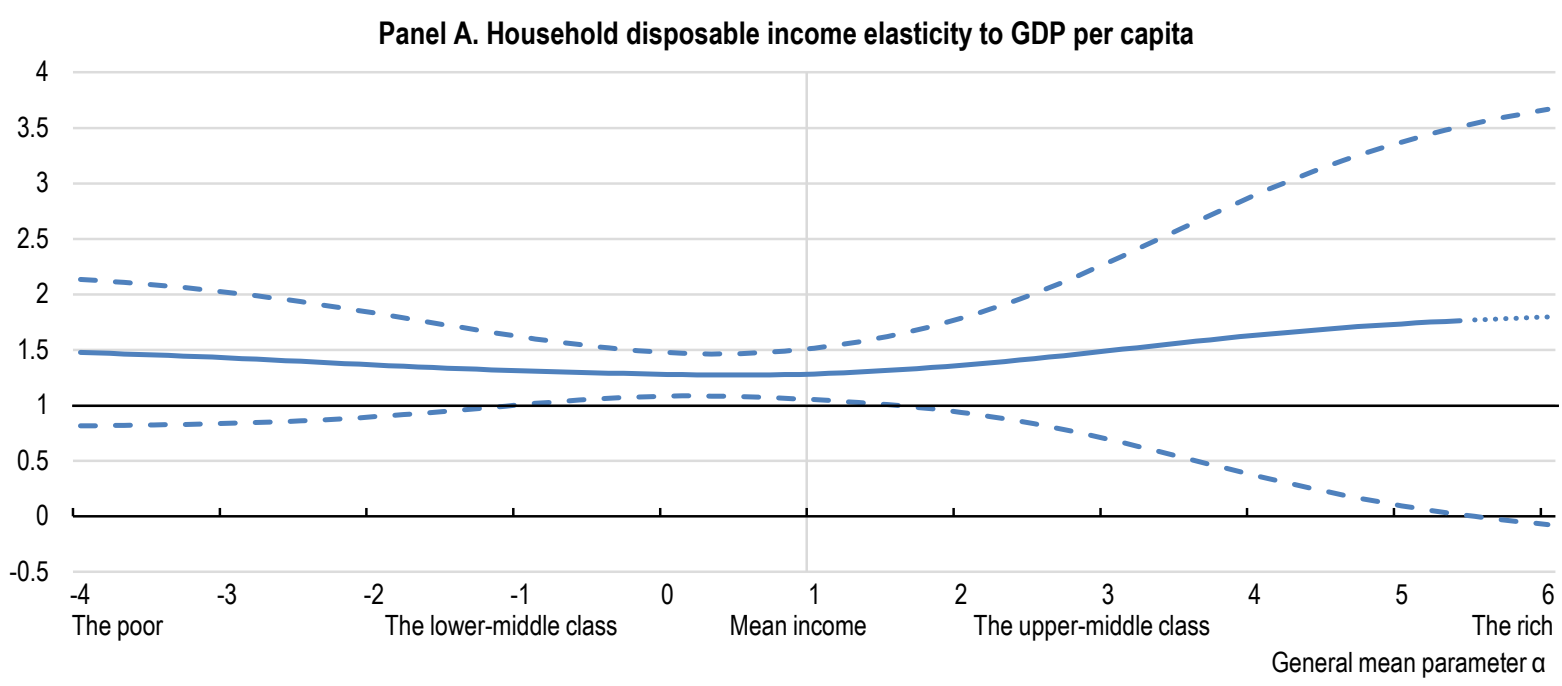

2.5

Panel B. Household disposable income elasticity to labour productivity

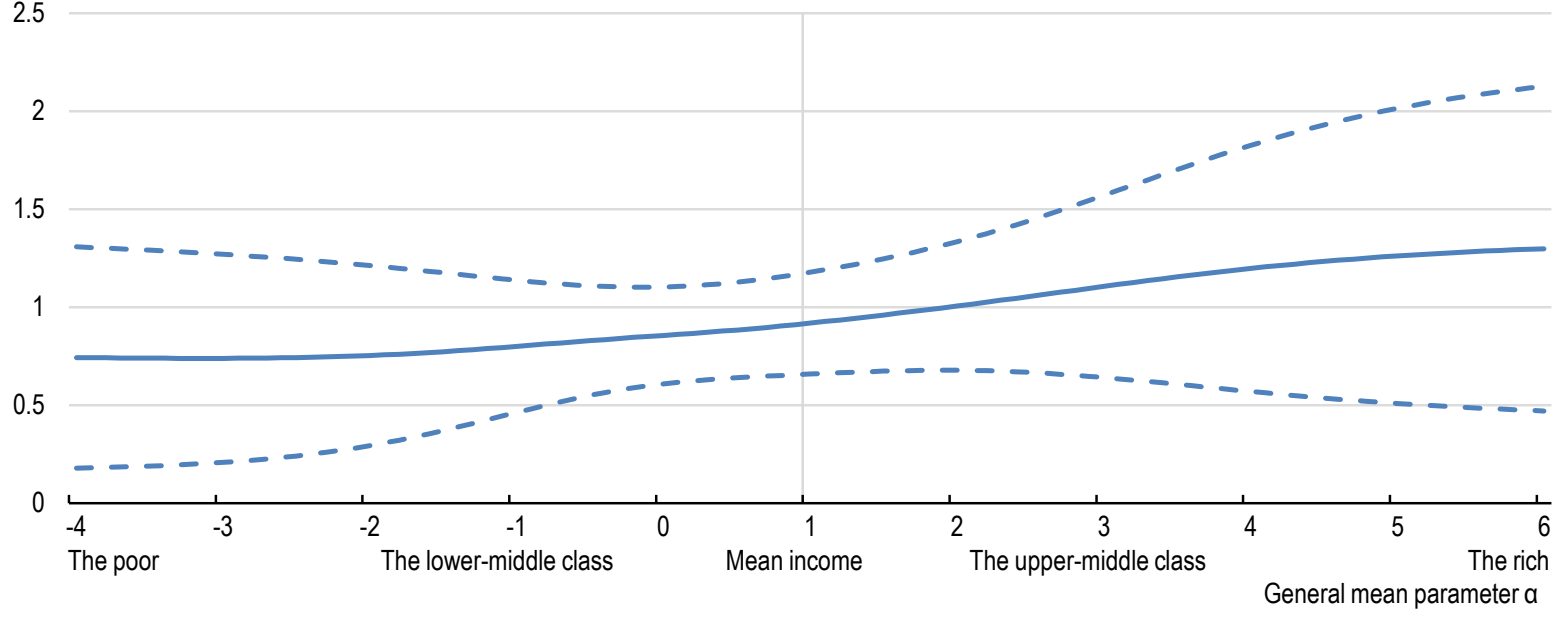

Panel C. Household disposable income elasticity to labour utilisation

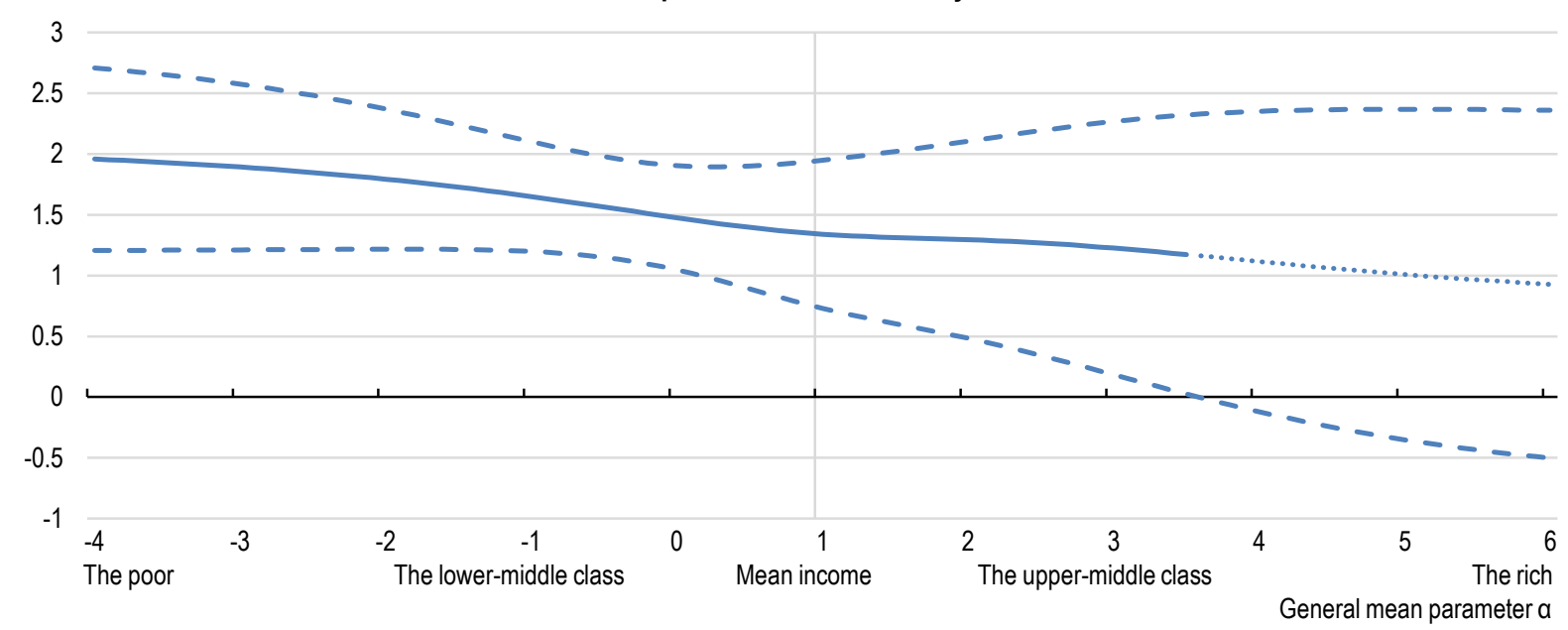

Note: Elasticities estimated by System GMM. See Hermansen et al. (2016) for details. Dashed lines represent the $90 \%$ confidence interval bands. 


\subsection{The distributional effects of structural reforms: a combined macro-micro approach}

15. The assessment of the effects of growth-enhancing reforms on income inequality is based on a combined macro-micro approach which encompasses growth and household incomes across the distribution (see Box 2 and Appendix for a detailed presentation). In this vein, the total effect of a given policy reform on household incomes can be interpreted and decomposed a follows (Figure 3):

Figure 3. The combined macro-micro approach

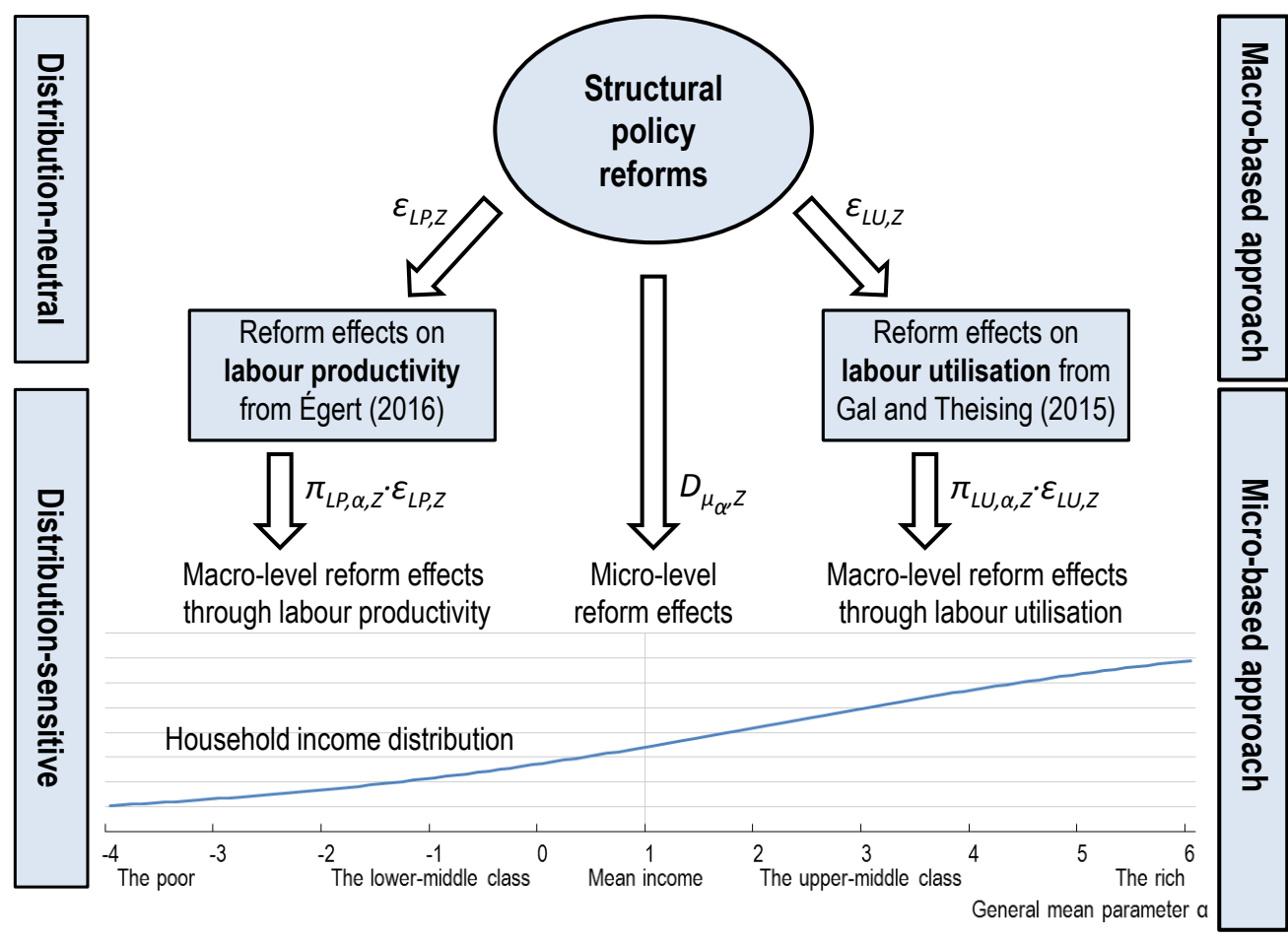

- Macro effects: reform-driven changes in labour productivity and/or labour utilisation which benefit household incomes across the distribution. This encompasses distribution-neutral effects calibrated on the basis of recent empirical analysis of the effects of structural reforms on growth and its components; that is, from Gal and Theising (2015) and from Egert (2016); with distributionsensitive effects derived from the policy-augmented baseline estimation, i.e. reform-driven changes in labour productivity and labour utilisation. Appendix A1 provides details about the way external estimates obtained in in above-cited papers are combined with internal estimates obtained in this paper with a view to ensure econometric consistency.

- Micro effects: reform-driven changes in household incomes which are not channelled through macroeconomic effects but add to reform-driven growth effects. The micro effects are based on new estimates of the effects of structural reforms on household incomes across the distribution. These estimates build on the baseline estimation framework. As a result, these micro reform effects on household incomes are conditional on growth effects. By contrast, they do not control for potential confounding effects from other reforms as well as for interaction effects with other reforms because the approach retained in this paper only allows policies to be considered in isolation (i.e. one at a time) This limitation should be kept in mind when interpreting the results, 
the risk being that estimated effects of a given policy change result from some simultaneous change in another policy area rather than the direct effect of the policy per se. However, the treatment of endogeneity in the estimation aims at lowering the effects of such confounding factors.

\section{Box 2. Assessing the impact of structural reforms on income distribution: a combined macro-micro framework $^{1}$}

The baseline model presented in the last section and specified in Box 1 aims at capturing the incidence of growth across the income distribution, i.e. the distributional effects of growth. This model can be augmented and combined with results on the quantification of the macroeconomic effects of structural reforms to deliver a complete assessment of the impact of structural reforms on household incomes across the distribution.

First, augmenting this baseline model with structural policy indicators $(Z)$ allows for identifying the micro effects of growth-enhancing policy reforms on the long-term level of household incomes across the distribution2, conditional on and beyond their impact channeled through growth and its sub-components, i.e. the macro effects:

$$
\begin{aligned}
\Delta \ln \mu_{\alpha}\left(x_{i t}\right)= & \theta_{0, \alpha}-\theta_{1, \alpha} \ln \mu_{\alpha}\left(x_{i t-1}\right)+\theta_{2, \alpha} \Delta \ln L P_{i t}+\theta_{3, \alpha} \ln L P_{i t-1}+\theta_{4, \alpha} \Delta \ln L U_{i t}+\theta_{5, \alpha} \ln L U_{i t-1} \\
& +\theta_{6, \alpha} N X_{i t}+\theta_{7, \alpha} Z_{i t-1}+\gamma_{t}+\eta_{i}+\varepsilon_{i t}
\end{aligned}
$$

Second, growth-enhancing policy reforms are deemed to deliver growth effects, i.e. changes in labour productivity $(L P)$ and labour utilisation $(L U)$. Such changes in labour productivity and labour utilisation benefit differentially household incomes across the distribution, i.e. growth effects also encompass distributional effects, as demonstrated in the baseline model. As a result, reform-driven macroeconomic effects generate macro effects on the long-term level of household incomes across the distribution. Such macro effects, available in the literature and in particular from on-going work conducted by the Economics Department (Gal and Theising, 2015; Egert, 2016), can be combined in a fully-fledged macro-micro approach.

The combination of all these effects can be written as follows (see the appendix to this paper for a complete analytical exposure of the approach):

$$
E_{\mu_{\alpha}, Z}=\pi_{L P, \alpha, Z} \cdot \varepsilon_{L P, Z}+\pi_{L U, \alpha, Z} \cdot \varepsilon_{L U, Z}+D_{\mu_{\alpha}, Z}
$$

Where $E_{\mu_{\alpha}, Z}$ denotes the long-run elasticity of household income in a given income group (governed by $\alpha$ ) with respect to a change in the policy variable $Z$. This corresponds to the total reform effect and combines mutually exclusive macro and micro effects:

- The first term captures the macro effect channeled through labour productivity. This is in turn the product of two effects: i) the distribution-sensitive return to household income from labour productivity growth $\left(\pi_{L P, \alpha, Z}\right)$, which is conditional on policies $Z$, and ii) distribution-neutral macroeconomic growth effects of a policy reform on labour productivity $\left(\varepsilon_{L P, Z}\right)$.

- The second term captures the macro effect channeled through labour utilisation, analogous to labour productivity.

- The third term $\left(D_{\mu_{\alpha}, Z}\right)$ captures micro distributional reform effects, i.e. distribution-sensitive changes in household income that are not driven by changes in labour productivity and labour utilisation. Those are estimated directly from (1) using System GMM estimation techniques and assuming policy variables are strictly exogenous.

Reform-driven macroeconomic effects $\left(\varepsilon_{L P, Z}\right.$ and $\left.\varepsilon_{L U, Z}\right)$ have been estimated in the context of a recent updated assessment of the quantitative impact of policies and institutions on labour utilisation and productivity (Gal and Theising, 2015; Egert, 2016). Distributional effects are estimated on the basis of the policy-augmented version of the baseline model (equation 1). These layers of empirical work are combined in a single framework in order to deliver a comprehensive assessment of the impact of structural policies on growth and the income distribution (see Appendix A1 for details on the approach and calculations).

1. See Appendix for details on the combined approach and calculation of the estimates.

2. Due to the limited degrees of freedom in the income distribution data used (e.g. short time horizon, break in the series, etc.), using SYS-GMM for the micro-effects precludes the estimation of multivariate reform scenarios (as well as the introduction of non-linear effects or interactions between policies). However, the lack of control for potential confounding factors is deemed to be attenuated by an appropriate treatment of endogeneity allowed by SYS-GMM. 


\section{The distributional effects of structural reforms: the results}

\subsection{Labour market and welfare policies}

\section{Social benefits and measures to facilitate the return to work}

Unemployment benefits (UB), social protection and active labour market polices (ALMPs)

16. Untargeted reductions in unemployment benefit replacement rates are found to lift disposable income among households from the lower-middle class to the rich, but not among the poor (Figure 4). This finding implies that reducing the generosity of unemployment benefits may trigger an increase in income inequality. This reflects the interplay of distributionally-offsetting mechanisms. Reducing benefit generosity is found to lift labour utilisation, and, via this channel, household incomes across the whole distribution, including among the poor. However, positive macro-level effects from higher labour utilisation are offset by negative micro-level disequalising effects affecting poor households, which explain why the total effect is not significant in that portion of the income distribution. One interpretation is that reform-driven increases in labour utilisation are associated with increases in wage dispersion among workers (through a reduction in reservation wages) as well as income dispersion between workers and benefit recipients (through lower social transfers). The finding of reform-driven disposable income increases among the upper middle class and the rich could also tentatively reflect that reductions in UB generosity are associated with reductions in income taxes which benefit the most affluent households.

Figure 4. Effects of a reduction in UB average gross replacement rates on household disposable incomes

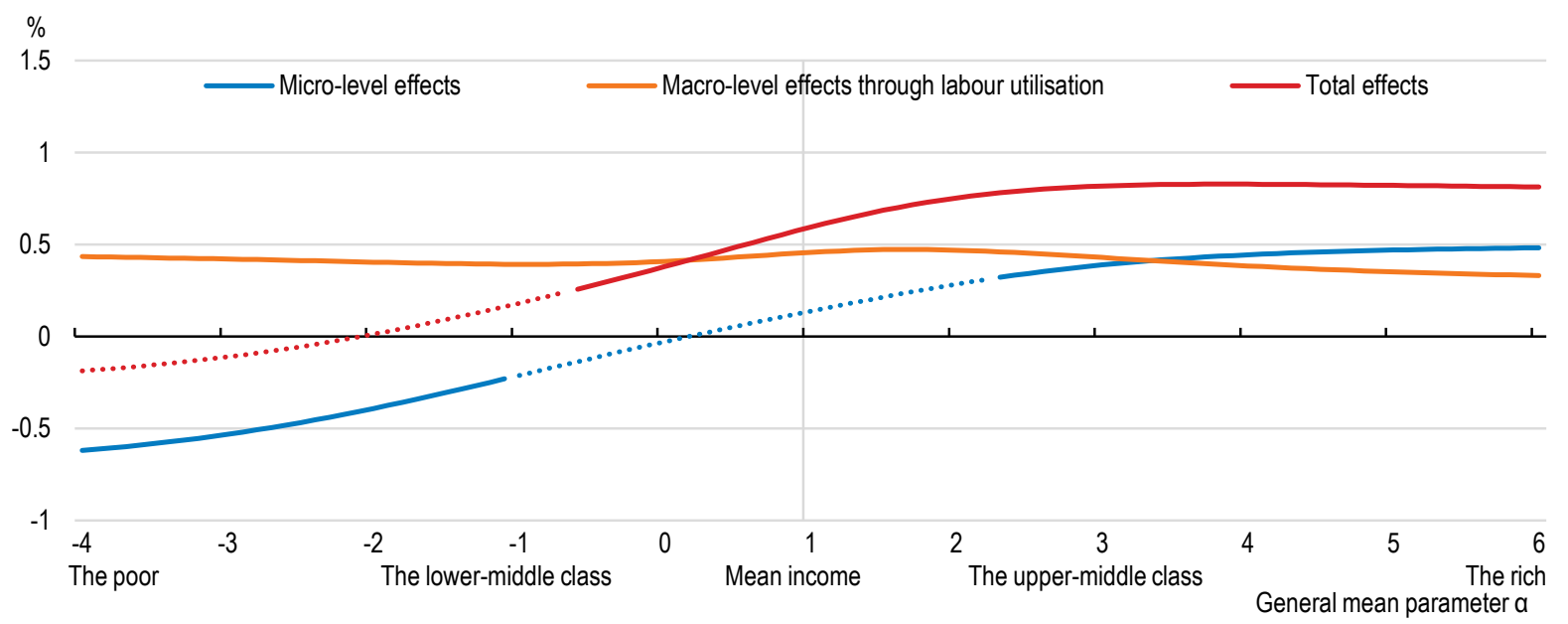

How to read this figure: A reduction in UB average gross replacement rates by 1 percentage point is estimated to increase household disposable income by $0.3-0.8 \%$ from the lower-middle class to the most affluent households. This total effect can be decomposed along a micro-level effect and macro-level effect through labour utilisation. See Box 2 for details of the empirical approach and the definition of the effects. Non-significant estimates (at the $10 \%$ level) are indicated by dots on general mean curves.

17. Reductions in benefit replacement rates targeted to the long-term unemployed (measured in the $60^{\text {th }}$ month of benefit receipt, hence including cash housing assistance and social assistance "top ups" if available) are found to increase inequality in household disposable income. This reflects income losses among the poor and the lower-middle class (Figure 5). This could reflect that targeting social benefit reforms to the long-term unemployed may fail to deliver significant employment gains because the longterm unemployed have usually lower chances to find a job relative to the recently unemployed, reflecting compositional effects as well as skills erosion. Indeed, the macro estimates fail to identify any significant labour utilisation gain as a result of targeted reductions in unemployment benefits, as opposed to untargeted reductions. As a result in this case, household income effects are only driven by micro-level 
disequalising effects. Those could again reflect increased wage dispersion as well as income dispersion between the long-term unemployed and the rest of the population.

\section{Figure 5. Effects of a reduction in UB net replacement rates for long-term unemployed on household disposable incomes}

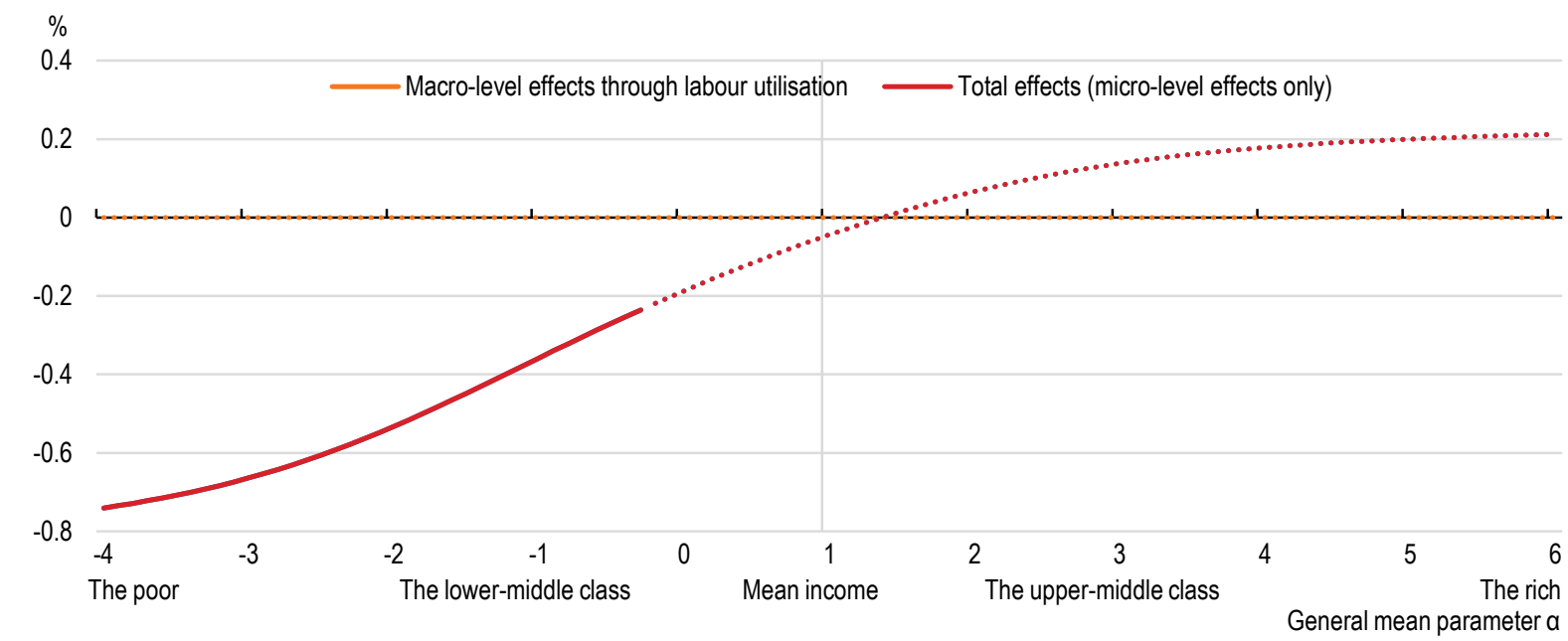

How to read this figure: A reduction in UB net replacement rates for long-term unemployed (single, $100 \%$ of average earnings, no children, 60th month of benefit receipt) by 1 percentage point is estimated to decrease household disposable incomes by $0.2-0.7 \%$ on average among the lower-middle class and the poor. This total effect comprises only the micro-level effect since the macro-level effect on labour utilisation is insignificant and thus set to zero. See Box 2 for details of the empirical approach and the definition of the effects. Non-significant estimates (at the $10 \%$ level) are indicated by dots on general mean curves.

18. Increasing spending on active labour market policies (ALMPs) is found to lift household incomes in the lower-middle class, but to leave household incomes in the rest of the distribution unaffected (Figure 6). Positive effects in the lower middle class may reflect that stepping-up job-search support and programmes for the unemployed can increase jobseekers' employment chances and wages once in employment. Indeed, the estimates identify a significant effect on labour utilisation but this effect does not allow for lifting the income of the poorest. ${ }^{21}$ This may signal the lower effectiveness of ALMPs at raising labour market outcomes among individuals at the low-end of the distribution, most likely the long-term unemployed and those that have dropped-out of the labour force. Positive macro-level effects through labour utilisation are compounded by negative micro-level effects, i.e. lower disposable incomes in the upper-half of the distribution, but macro and micro effects offset each other and the total effect is not statistically significant. One potential interpretation of this latter finding is that higher spending on ALMPs tends to be associated with higher income taxes, with stronger incidence on the middle class and most affluent taxpayers.

21. Note that the effect of labour utilisation on household incomes is conditional on policies included in the model. That is why such effect can differ from that estimated in the baseline model (with no policy variable included, Figure 2). Hence, conditional on ALMPs, labour utilisation growth has no significant effect on household income among the poor (Figure 6). 
Figure 6. Effects of an increase in ALMP spending on unemployed on household disposable incomes

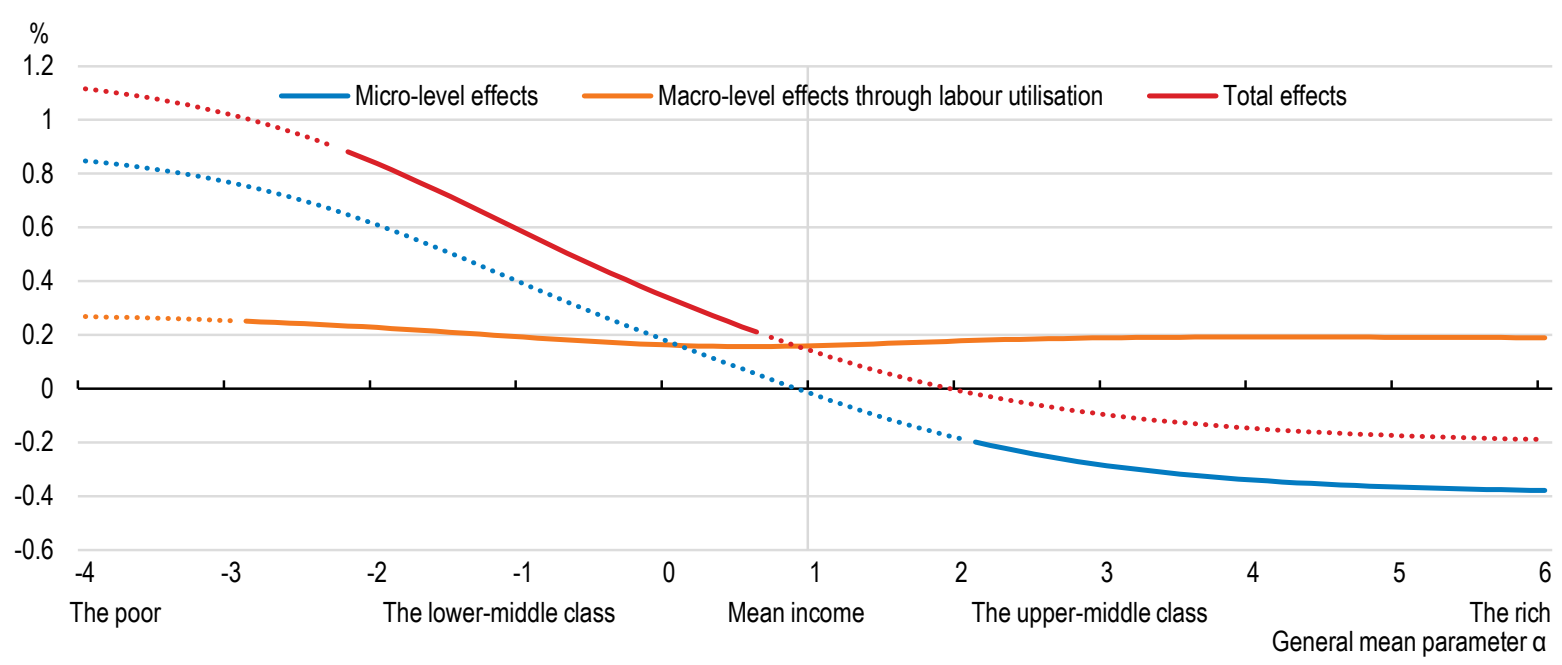

How to read this figure: An increase in ALMP spending per unemployed (measured in per cent of GDP per capita and by the trend component from an HP-filter) by 1 percentage point is estimated to increase household disposable incomes by $0.2-0.8 \%$ on average among the lower-middle and middle class. This total effect can be decomposed along a micro-level and macro-level effect through labour utilisation. See Box 2 for details of the empirical approach and the definition of the effects. Non-significant estimates (at the $10 \%$ level) are indicated by dots on general mean curves.

19. Overall, the results of this section suggest that the design and generosity of unemployment benefits requires a balanced approach to support high-quality job-search assistance and matching efficiency. The results also suggest that reducing the generosity of unemployment benefits need to be combined with well-targeted ALMPs with a view to achieving labour market inclusiveness, in particular by enhancing employability at the low-end of the distribution such as among the low-skilled, the long-term unemployed and discouraged jobseekers.

\section{Retirement schemes}

20. Higher legal retirement age is associated with higher disposable incomes for the vast majority of households, and associated income gains are of similar magnitude between income groups (Figure 7). This reflects reform-driven increases in older worker employment rates, which benefit household incomes across the distribution, with the exception of rich households that are found to be unaffected. This result is in line with previous abundant evidence on the employment effects of increases in legal retirement age. The finding that such effect is broadly distribution-neutral tentatively indicates that older workers at the low end of the income distribution have been successful at remaining employed, at least on average across OECD countries over the period under consideration. The finding in this paper that increasing retirement age does not trigger a change in inequality needs however to be interpreted with caution. Indeed, a proper assessment of reform-driven distributional effects should ideally rely on micro-based estimates by age and income group, which is beyond the scope of this paper. In any case, from a broader perspective, reforms in this area should be designed to allow for choice in work and retirement decisions (including part-time employment) and combined with policy measures ensuring employability of older workers. ${ }^{22}$

22. OECD (2015b, 2015c). 
ECO/WKP(2016)66

Figure 7. Effects of an increase in the legal pension age on household disposable incomes

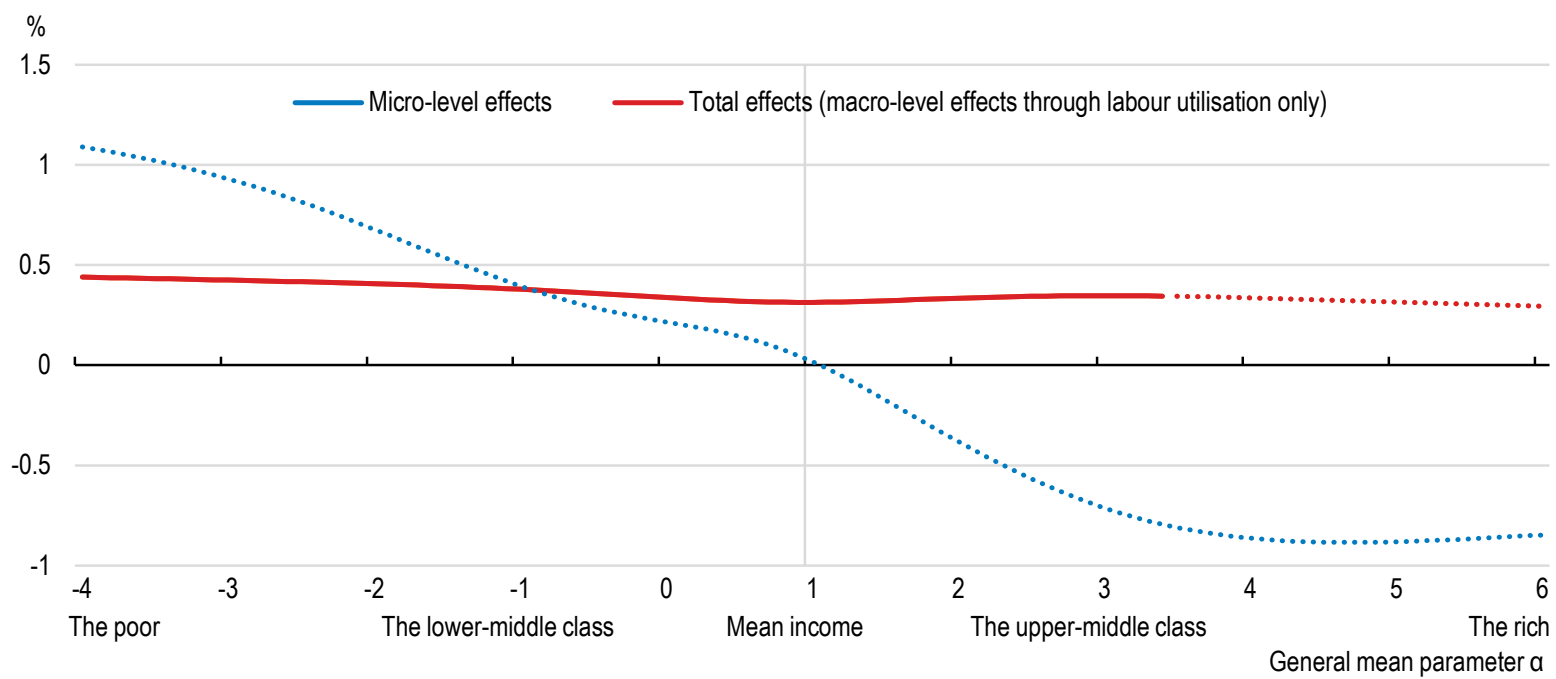

How to read this figure: An increase in the legal pension age by 1 year is estimated to increase household disposable incomes by $0.3-0.4 \%$ on average from the poor to the upper middle class. This total effect comprises only the macro-level effect through labour utilisation since the micro-level effect is insignificant for all income groups. See Box 2 for details of the empirical approach and the definition of the effects. Non-significant estimates (at the $10 \%$ level) are indicated by dots on general mean curves.

Family benefits

21. Increasing public spending on services for families with children (i.e. family benefits in kind) is found to reduce income inequality by boosting household incomes in the middle class and, even more so, among the poor; while depressing household incomes among the rich (Figure 8). Overall, this implies a reduction in income inequality. ${ }^{23}$ Such spending covers direct financing and subsidising of providers of childcare and early-education facilities, public childcare support through earmarked payments to parents, public spending on assistance for young people and residential facilities, public spending on family services, including centre-based facilities and home help services for families in need. Associated services generally feature progressivity in the sense that they disproportionately benefit less affluent households. Indeed, distribution-sensitive estimates indicate micro-level equalising effects from family benefits in kind.

22. The estimated negative micro-level household income effect in the upper half of the distribution could reflect that higher spending tends to be associated by higher income taxes, with stronger incidence on the middle class and most affluent taxpayers. The macro estimates deliver distribution-neutral labour utilisation effects, which are driven by increases in prime-aged women employment. Overall, this finding confirms that putting public resources on quality early-childhood education delivers high economic and social payoff. ${ }^{24}$ Encouraging access by disadvantaged families not only helps integrating women in the labour market but also raises children's returns to later stages of the education system.

23. This result echoes recent evidence on the effect on public spending on inequality and growth (Fournier et al., 2016).

24. http://www.oecd.org/education/school/48980282.pdf 
Figure 8. Effects of an increase in family in-kind benefits on household disposable incomes

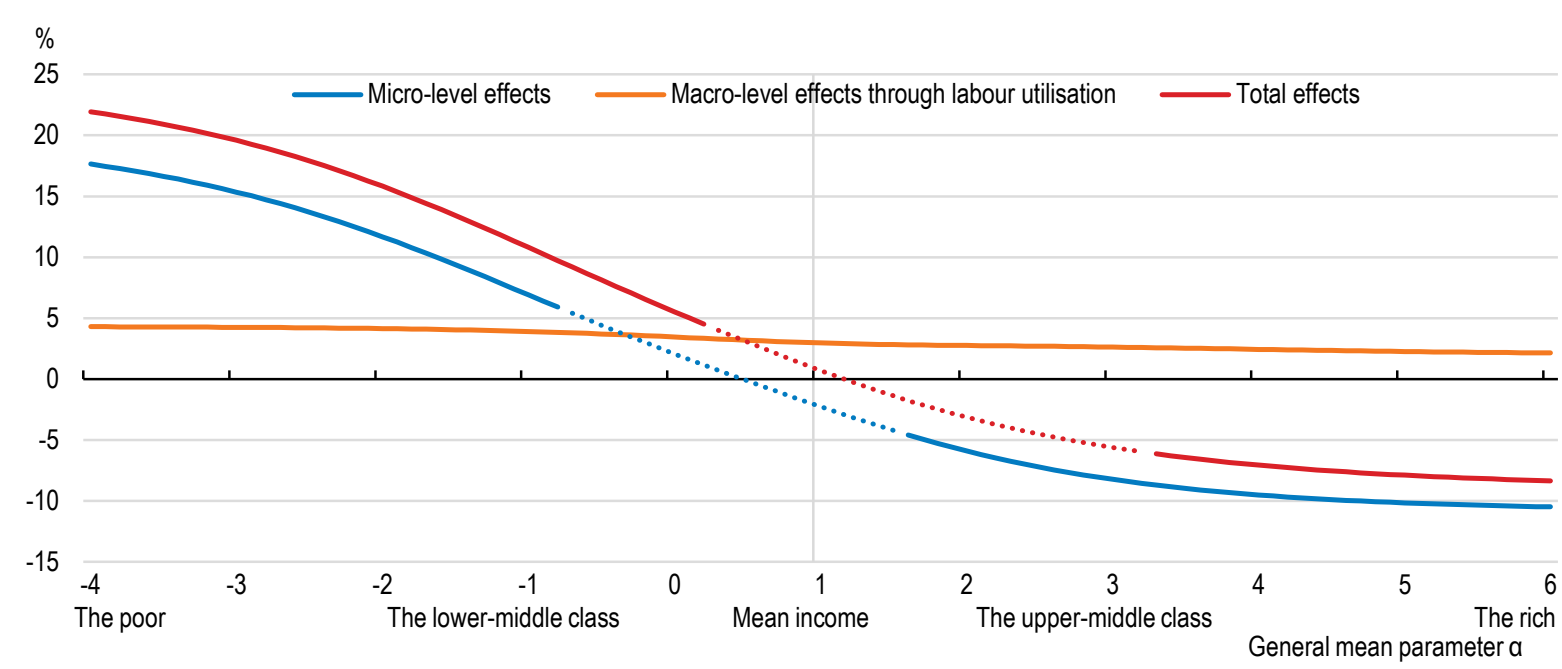

How to read this figure: An increase in family in-kind benefits (measured in per cent of GDP) by 1 percentage point is estimated to increase household disposable incomes by $5-22 \%$ on average from the lower-middle class to the poor and decrease incomes by 6 $8 \%$ from the upper-middle class to the rich. This total effect can be decomposed along a micro-level effect and macro-level effect through labour utilisation. See Box 2 for details of the empirical approach and the definition of the effects. Non-significant estimates (at the $10 \%$ level) are indicated by dots on general mean curves.

\section{Labour market regulations and collective wage agreements}

Job protection

23. Reducing job protection for regular contracts is found to depress household incomes in the lowermiddle class and among the poor (Figure 9). Associated reforms are thus found to increase inequality. This reflects disequalising micro-level effects through reform-driven household income declines in the bottom of the distribution; while macro-level estimates fail to identify any robust effect from job protection on either labour utilisation or labour productivity. The finding that reducing job protection delivers relatively pronounced disequalising effects on household incomes could reflect rising wage dispersion. Earlier studies have shown that job protection legislation tends to protect wages of low skilled workers with little bargaining power to a larger extent than those of high skilled workers and that, as a result, reducing job protection tends to widen wage inequality. ${ }^{25,26}$

25. OECD (2011), Checchi and Garcia-Penalosa (2008), Braconier and Ruiz-Valenzuela (2014).

26. The finding that more stringent employment protection is associated with lower income inequality has been recently confirmed on the basis of a newly developed policy index and a wide cross-country dataset, covering developed and developing countries since 1960. See Campos and Nugent (2012). 
Figure 9. Effects of a reduction in EPL for regular contracts on household disposable incomes

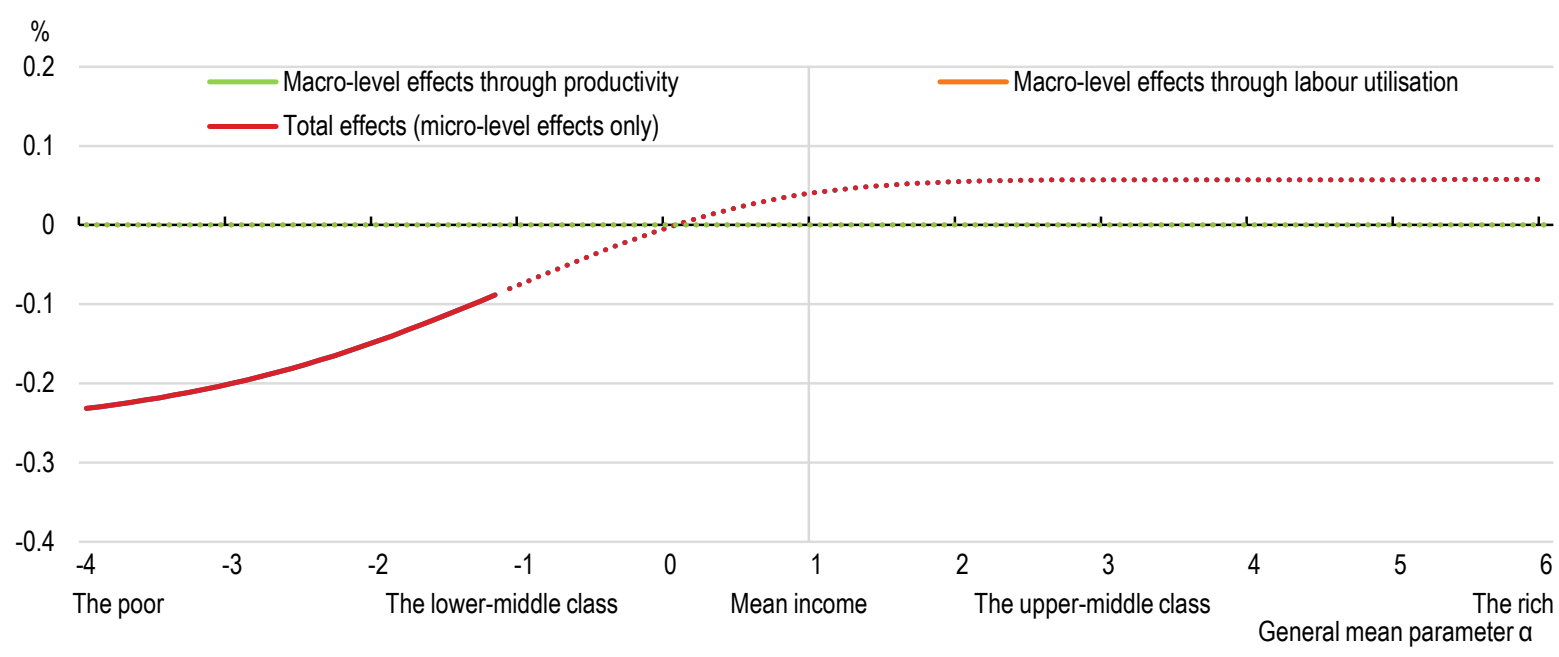

How to read this figure: A reduction in EPL for regular contracts (index $0-6$ ) by $1 \%$ is estimated to decrease household disposable income by $0.1-0.2 \%$ among the poor and the lower-middle class. This total effect comprises only the micro-level effect since the macro-level effects on labour productivity and labour utilisation are insignificant and thus set to zero. See Box 2 for details of the empirical approach and the definition of the effects. Non-significant estimates (at the $10 \%$ level) are indicated by dots on general mean curves.

24. The absence of a robust macro impact on productivity from reducing job protection could reflect the interplay of opposite mechanisms offsetting each other at the aggregate level (Egert, 2016). On the one hand, associated reforms have been found in earlier studies based on disaggregated data to boost multifactor productivity by enhancing workers' reallocation across firms and industries. ${ }^{27}$ On the other hand, associated reforms may also reduce incentives to invest in training by firms and workers, and this negative effect on labour productivity may counteract the positive effect through improved labour reallocation. Indeed, some studies based on aggregate data have reported negative labour productivity effects from reductions in job protection. ${ }^{28}$

25. Finally, the absence of significant macro-level employment gains from easing job protection legislation (Gal and Theising,2015) is in line with earlier studies which, based on job flow data, have shown ambiguous aggregate employment effects, as lower job protection tends to raise both unemployment inflows and outflows. ${ }^{29}$ It could also reflect a compositional effect: the idea is that stringent job protection may reduce employment among the low-skilled even if this does not translate into lower aggregate employment. Indeed, Gal and Theising (2015) find that stringent job protection reduces employment among the low-educated but has the opposite effect among the high-educated, hence has no effect on aggregate employment. However, current micro-level estimates shown in Figure 9 do not allow for corroborating such interpretation, since they indicate negative effects on incomes among poor households.

26. The policy implications from these findings should be drawn with care and more work is needed to assess the growth and inequality effects of job protection, which is currently hampered by data

27. See Andrews and Cingano, (2012); Bassanini et al. (2009), Bassanini and Garnero, (2013).

28. Belot et al. (2007); Koeniger (2005), Nickell and Layard (1999). Autor et al. (2007) find that increases in job protection had a negative effect on multifactor productivity but a positive effect on labour productivity.

29. See Andrews and Cingano, (2013); Bassanini et al. (2009), Bassanini and Garnero, (2013). 
limitations in the time-series dimension. ${ }^{30}$ For instance, it fails to capture properly the impact of unbalanced job protection, that is, an institutional setting under which regular workers benefit from significantly higher job protection than non-regular workers, is associated with high prevalence of nonstandard work and labour market segmentation. In fact, recent evidence based on a difference-in-difference estimation framework suggests that flexibility-enhancing EPL reforms (as measured through a dummy variable taking value 1 when the EPL indicator decreases and 0 otherwise) increase average wages and labour utilisation of the low-educated in the long-run. ${ }^{31}$ Job protection reforms aimed at addressing labour market segmentation and duality can contribute to enhance labour market inclusiveness and this may ultimately curb income inequality, as discussed in Chapter 4 of OECD (2015b).

\section{Unionisation and minimum wages}

\section{Unionisation and wage bargaining}

27. Declining union density is associated with declining household disposable incomes among the poor, while the middle and upper-half of the distribution are not affected, implying an increase in income inequality (Figure 10). This finding is consistent with the well-known equalising impact of unions on wage dispersion, an established result in the literature on wage setting institutions (see Chapter 3 in OECD, 2004). However, it could also reflect the fact that stronger unions may push for more income redistribution: ${ }^{32}$ this would be supported by the fact that significant effects are estimated only in the bottom of the disposable income distribution, where most households rely on government transfer income rather than market income. Moreover, macro-based estimates fail to identify any effect of union density on labour utilisation - implying that household income effects are exclusively driven by micro-based estimated effects. Nevertheless, it needs to be stressed that union density is only an indirect proxy for workers' bargaining power. The results obtained here could be driven by number of OECD-wide trends that simultaneously increased inequality and decreased union density along with workers' bargaining power, such as rising non-standard work.

28. Phasing out administrative extension of collective agreements to non-union members is found to lift labour utilisation, and, through this channel, household disposable incomes in the middle class and among the poor; leaving, as was the case for union density, rich households unaffected (Figure 11). This finding could reflect that when the fraction of workers covered by collective agreements is very high relative to union density, unions do not internalise the effects of their wage demands on the whole workforce (Murtin et al., 2014). These demands may thus lead to unemployment, as found in Bouis et al. (2012). Positive reform-driven effects on labour utilisation are therefore in line with previous papers and such effects tend to reduce disposable income inequality. At the same time, in previous papers, extensions of collective agreements have been found to limit wage inequality (Villanueva, 2014). The interplay between the two effects implies a priori an ambiguous effect on disposable income inequality. The current results would tend to suggest that the reform-driven increases in employment more than offset reformdriven increases in wage dispersion. Reducing excess coverage of collective agreements may thus contribute to labour market inclusiveness. ${ }^{33}$

30. Specifically, the weak variation of the policy indicator over time makes it difficult to identify a robust effect in an econometric setting that controls for country fixed effects, since such setting exploits the within-country variation for identification purposes.

31. OECD (2016), Chapter 3.

32. Korpi (2006), Jaumotte and Osorio-Buitron (2015).

33. In fact this result is in line with Jaumotte and Osortio-Buiron (2015) who find that reducing excess coverage is income equalising, when inequality is measured by the Gini coefficient. 
Figure 10. Effects of a reduction in union density on household disposable incomes

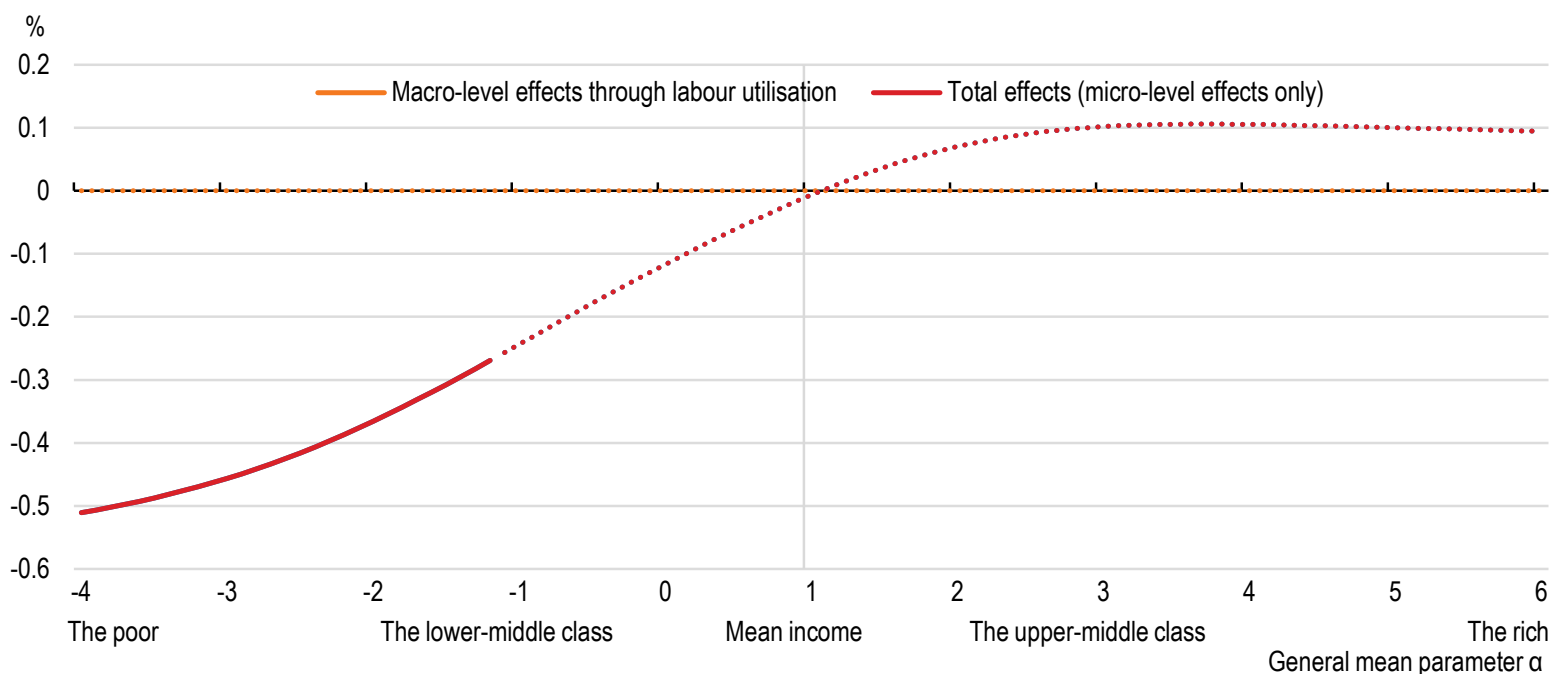

How to read this figure: A reduction in union density by 1 percentage point is estimated to decrease household disposable incomes by $0.3-0.5 \%$ on average among the lower middle-class and the poor. This total effect comprises only the micro-level effect since the macro-level effect on labour utilisation is insignificant and thus set to zero. See Box 2 for details of the empirical approach and the definition of the effects. Non-significant estimates (at the $10 \%$ level) are indicated by dots on general mean curves.

Figure 11. Effects of a reduction in excess coverage of collective agreements on household disposable incomes

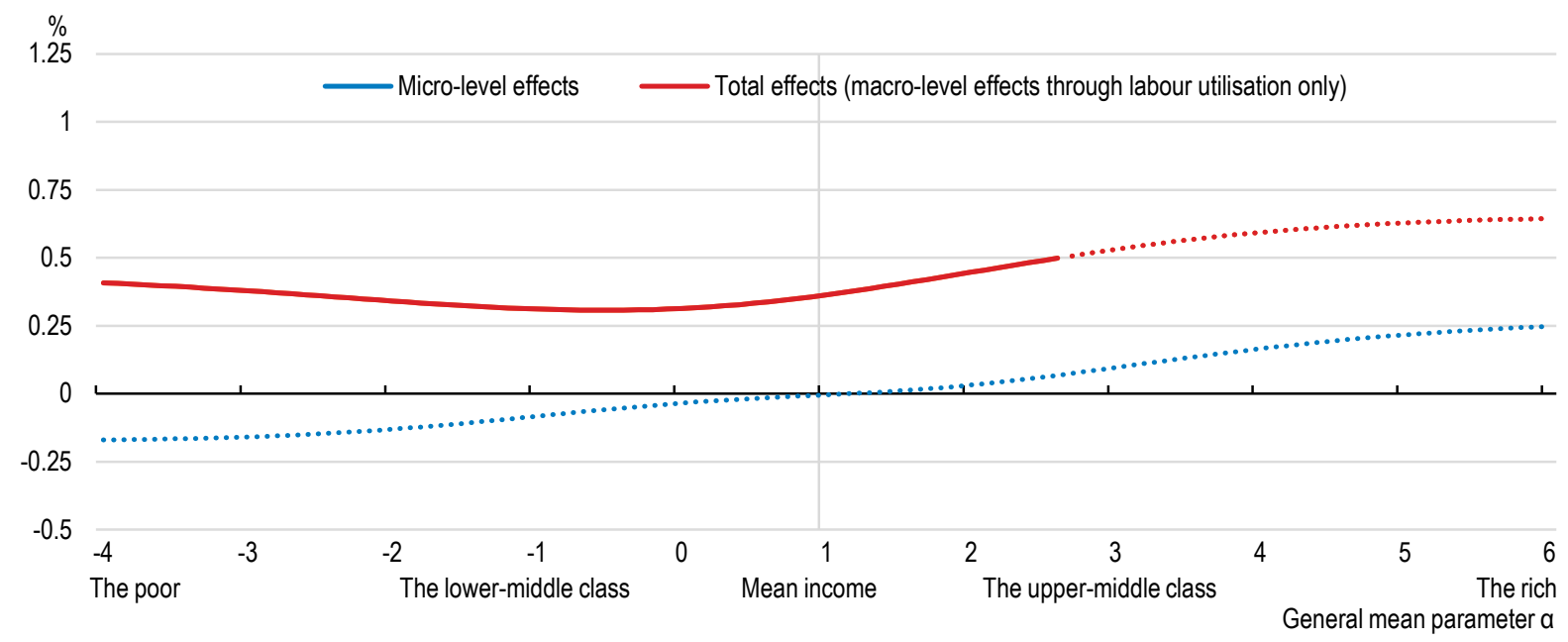

How to read this figure: A reduction in excess coverage of collective agreements (wage bargaining coverage less union density) by 1 percentage point is estimated to increase household disposable incomes by around $0.5 \%$ on average among the poor and in the middle class. This total effect comprises only the macro-level effect through labour utilisation since the micro-level effect is insignificant for all income groups. See Box 2 for details of the empirical approach and the definition of the effects. Non-significant estimates (at the $10 \%$ level) are indicated by dots on general mean curves.

29. Increasing the degree of wage bargaining coordination ${ }^{34}$ is found to reduce income inequality by boosting household incomes in the low end of the distribution and, to a lesser extent, in the middle class;

34. Coordination may be defined as the synchronisation of pay policies of distinct bargaining units and its measurement is not straightforward. In this study, coordination levels distinguishes the following practices (from low to high): fragmented company/plant bargaining, little or no co-ordination by upper-level 
while having no significant overall impact on household incomes in the high end of the distribution (Figure 12). This finding likely reflects that overall earnings dispersion is lower where collective bargaining is more coordinated, another well-established result in the literature on wage setting institutions (OECD, 2004). ${ }^{35}$ Coordinating pay negotiations across the economy allows for taking into account any consequences of settlements in the full economy, hence offsetting the potential adverse impact of unions' wage demands on labour market outcomes. Indeed, total household income effects are decomposed along macro-level effects through higher employment, which are equally shared across the distribution; and micro-level equalising effects (between the most and the least affluent households), which could reflect reform-driven declines in wage dispersion. Overall, the results of this section suggest that phasing out administrative extension of collective agreements while ensuring a high degree of wage bargaining coordination may boost labour market performance and at the same time reduce income inequality. Still, the complexity and heterogeneity of collective bargaining systems across OECD countries warrant a cautious interpretation of these results. They may also mask non-linearities in the employment and inequality effects of wage-setting institutions, which cannot be addressed in this study. ${ }^{36}$

Figure 12. Effects of an increase in the degree of coordination of wage-setting on household disposable incomes

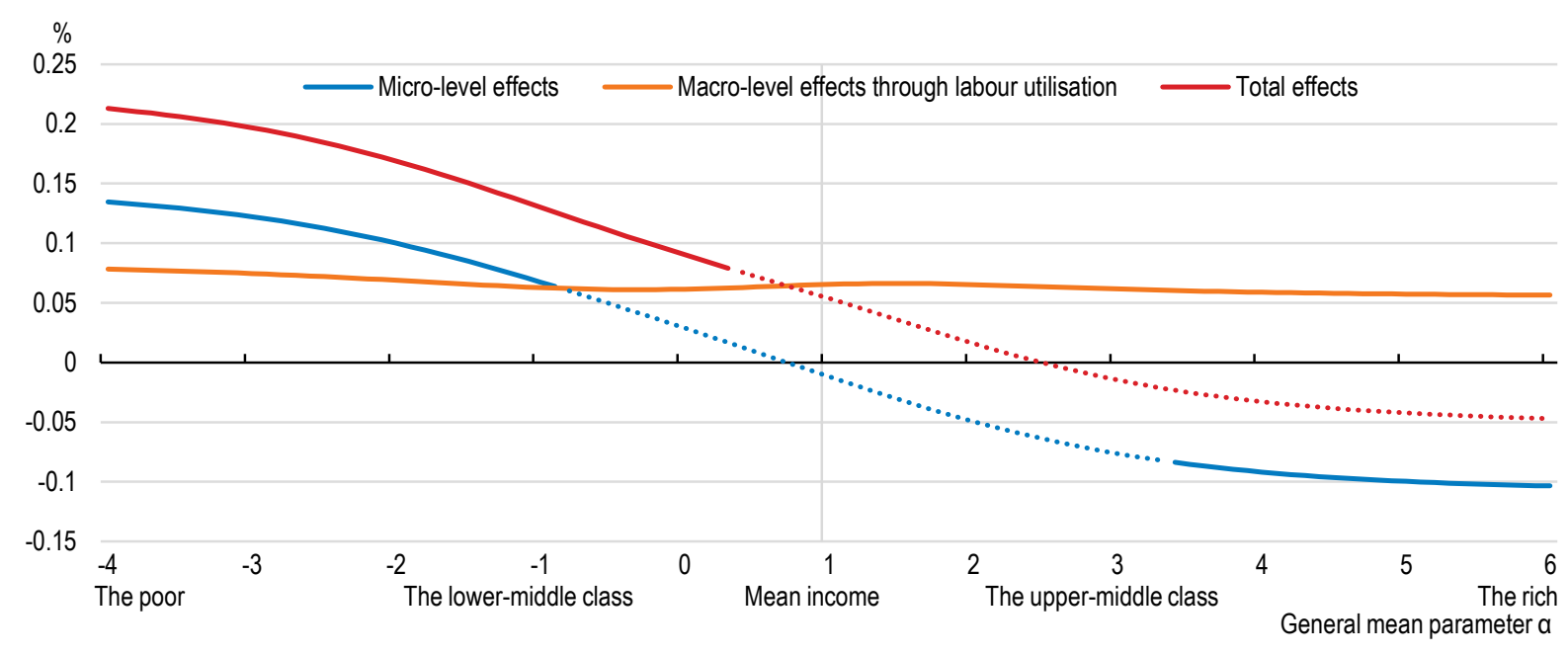

How to read this figure: An increase in the degree of coordination of wage setting coverage (index $1-5$ ) by $1 \%$ is estimated to increase household disposable incomes by $0.1-0.2 \%$ on average among the poor and the lower-middle class. This total effect can be decomposed along a micro-level effect and a macro-level effect through labour utilisation. See Box 2 for details of the empirical approach and the definition of the effects. Non-significant estimates (at the $10 \%$ level) are indicated by dots on general mean curves.

Minimum wages

30. Reducing minimum relative to median wages is found to lift labour utilisation, and, through this channel, household disposable incomes from the poor to the upper-middle class. However, such micro-

associations; fragmented industry and company-level bargaining, with little or no pattern-setting; industrylevel bargaining with irregular pattern-setting and moderate co-ordination among major bargaining actors and; two forms of stronger coordination, each uncovering different industrial relation structure (e.g. government wage arbitration or informal co-ordination of industry-level bargaining by an encompassing union confederation). This makes it clear that different systems can lead to similar levels of coordination.. See OECD (2004) for a discussion.

35. Recent findings have challenged this result and pointed to a more mixed picture (Addison, 2015).

36. Non-linearities can reflect several mechanisms such as well-known arguments by Calmfors and Driffil on the "hump-shaped" relationship between the degree of centralisation and employment. 
level equalising effects are offset by macro-level disequalising effects, that is, negative household income effects which are statistically significant at the low-end of the distribution (Figure 13). The finding of disequalising effects could reflect reform-driven increases in wage dispersion. However, the results would suggest that rising income inequality between workers is compensated by declining income inequality through employment creation: indeed, total effects are statistically non-significant at the level of household disposable incomes. In the end, reflecting the interplay between two offsetting effects, minimum wage reductions are found to leave the distribution of household disposable incomes unchanged, on average across OECD countries over the period under consideration. One cautions implication would be that when the level of minimum relative to median wages is such that it prices out low-skilled individuals from the labour market, some moderate reduction has the potential to create jobs without widening income inequality. ${ }^{37}$

\section{Figure 13. Effects of a reduction in minimum relative to median wage on household disposable incomes}

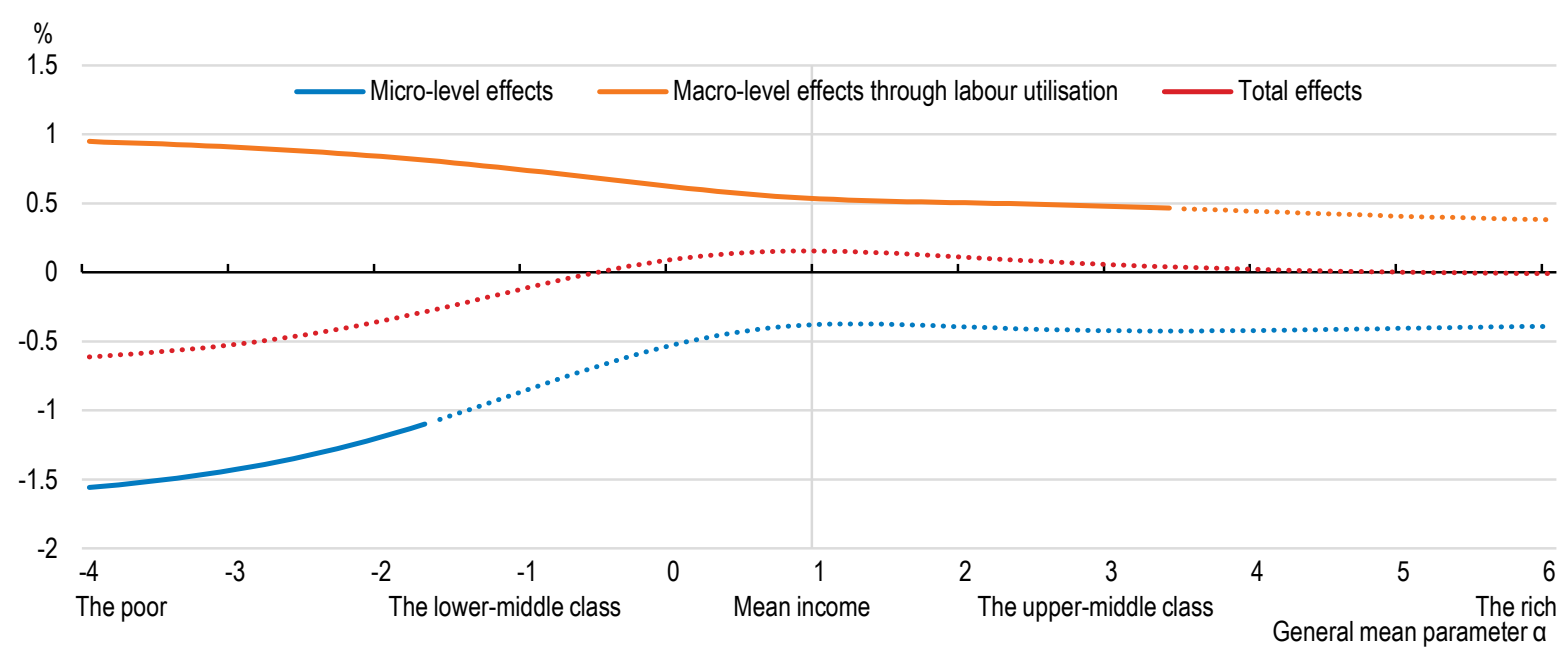

How to read this figure: A reduction in the minimum wage relative to the median by 1 percentage point is estimated to have no significant effects on any income groups. This total effect can be decomposed along a negative micro-level effect and a positive macro-level effect through labour utilisation counteracting each other. See Box 2 for details of the empirical approach and the definition of the effects. Non-significant estimates (at the $10 \%$ level) are indicated by dots on general mean curves. The minimum wage relative to the median is measured in deviation from the cross-country mean and a dummy for presence of a minimum wage is included as additional control variable in the estimation (see Gal and Theising, 2015).

\subsection{Tax policy}

31. Unfinanced reductions in the labour tax wedge are found to boost household incomes in the upper-middle class and the top of the distribution, while not affecting the lower-middle class and bottom of the distribution (Figure 14). This implies that associated reforms may widen income inequality by benefitting disproportionately richer households. However, total household income effects result from the interaction of distributionnally-offsetting macro and micro effects: on the one hand, reducing the labour tax wedge is found to raise labour utilisation, which tends to benefit disproportionately households in the bottom of the distribution, hence to reduce income inequality. On the other hand, positive macro-level equalising effects from higher labour utilisation are offset by negative micro-level disequalising effects which are statistically significant at the very low-end of the distribution. These disequalising effects may reflect reform-driven increases in wage dispersion which tend to counteract equalising effects from job

37. See OECD (2015d) for a comprehensive discussion and meta-analysis on the effect of minimum wages on employment. 
creation, along similar tentative interpretational lines than the ones proposed for the minimum wage estimates. Another potential interpretation could be that, all else equal, past reductions in the labour tax wedge may have resulted in lower progressivity of the income tax schedule.

Figure 14. Effects of a reduction in the labour tax wedge for one-earner couples on household disposable incomes

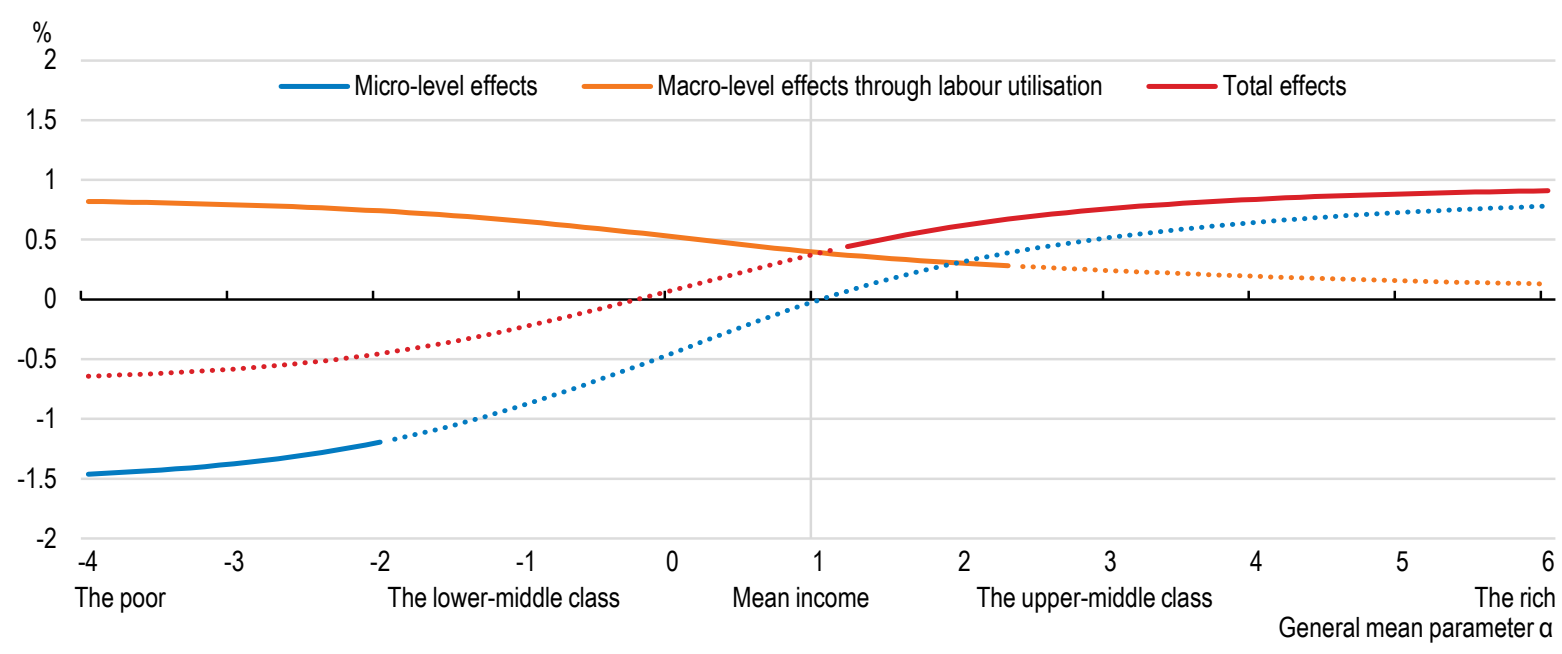

How to read this figure: A reduction in the labour tax wedge for a one-earner couple (100/0\% of average earnings, 2 children) by 1 percentage point is estimated to increase household disposable incomes by $0.5-0.9 \%$ on average from the middle class to the rich. This total effect can be decomposed along a micro-level effect and macro-level effect through labour utilisation. See Box 2 for details of the empirical approach and the definition of the effects. Non-significant estimates (at the 10\% level) are indicated by dots on general mean curves.

32. The effect of reducing labour taxes is indeed likely to depend on reform design. Financing mechanisms are likely to play a role depending on whether the reform is revenue-neutral and, in such a case, whether it is financed through increases on e.g. more progressive taxes such as property taxes or less progressive taxes such as consumption taxes. Indeed, revenue-neutral reductions in the labour tax wedge are found to boost household incomes among the poor and the middle class without affecting incomes among the rich (Figure 15). This is driven by equalising gains in labour utilisation. This finding, in comparison with that on unfinanced tax reductions, could suggest that, on average over the period over consideration, reductions in labour taxes have been financed by increases in more progressive taxes. The extent to which tax reductions are targeted is also likely to play a role, as mentioned before. Untargeted reductions may have reduced the progressivity of labour taxation, which would tend to increase inequality in disposable income, all else equal; by contrast targeted reductions to low-wage individuals would tend to have an opposite and equalising effect. This cannot be investigated with the data at hand, and more work is needed to uncover such effects. 
Figure 15. Effects of a tax revenue-neutral reduction in the labour tax wedge for one-earner couples on household disposable incomes

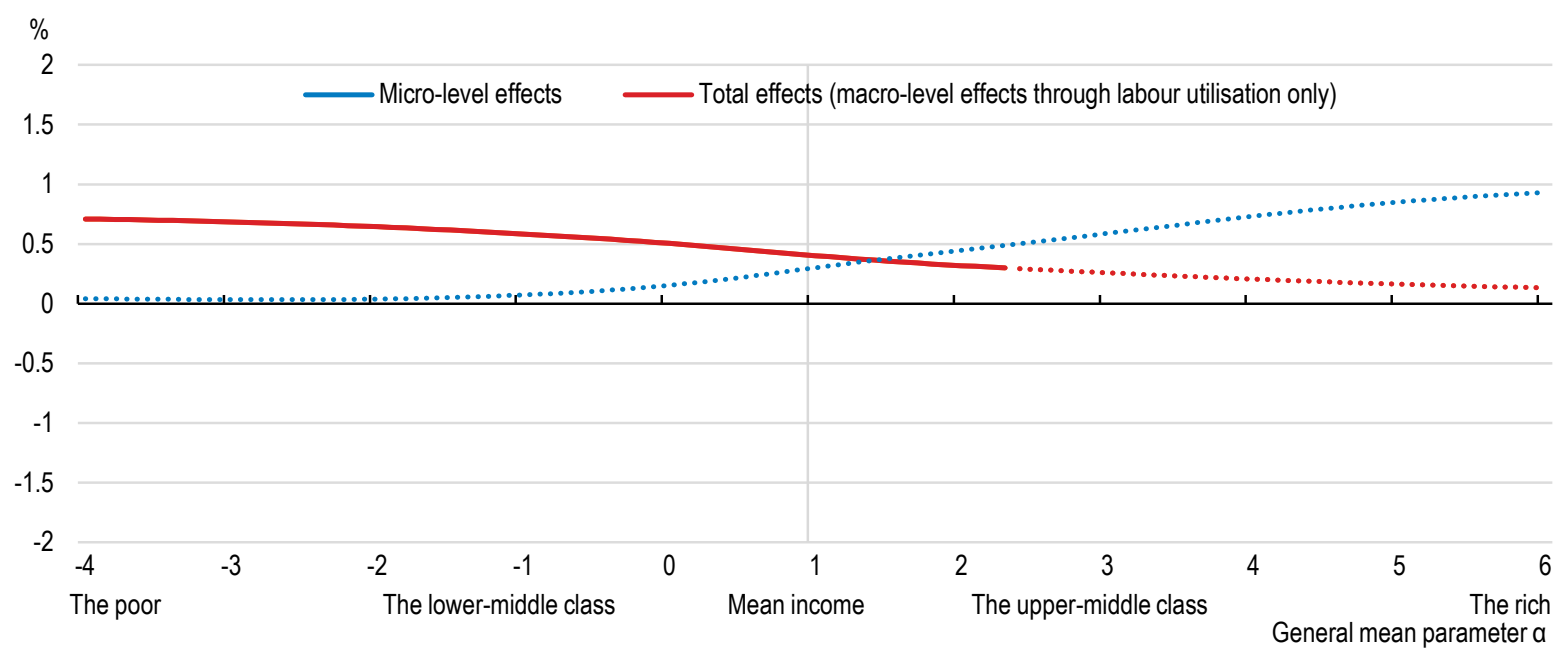

How to read this figure: A reduction in the labour tax wedge for a one-earner couple (100/0\% of average earnings, 2 children) by 1 percentage point is estimated to increase household disposable incomes by $0.3-0.7 \%$ for the poor and the middle class. This total effect comprises only the macro-level effect through labour utilisation since the micro-level effect is insignificant for all income groups. See Box 2 for details of the empirical approach and the definition of the effects. Non-significant estimates (at the $10 \%$ level) are indicated by dots on general mean curves. Total tax revenue in per cent of GDP is included as an additional control variable.

\subsection{Education, technological progress and globalisation}

\section{Education}

33. Increasing public spending on education is found to boost household incomes, especially among the poor (Figure 16). This finding is driven by macro-level disequalising effects through gains in labour productivity, which tend to boost incomes across the whole distribution but accrue slightly more to rich households; and micro-level equalising income effects, which tend to reduce disposable incomes in the upper-middle class and among the rich while boosting disposable incomes among the poor, with only this latter positive effect being statistically significant. Overall, increasing public spending on education is found to reduce household income inequality. This result may signal that public spending on education has been progressive over the period under consideration, on average across OECD countries. This may reflect the trend towards increased emphasis on programmes targeted to poor households such as children from disadvantaged backgrounds and youth at risk of dropping out from upper-secondary education. The tendency for increasing co-funding with the private sector at the tertiary level could have allowed public spending to be re-oriented on more inclusive programmes such as vocational education, requalification, but also childcare, as discussed before. 
Figure 16. Effects of an increase in government spending on education on household disposable incomes

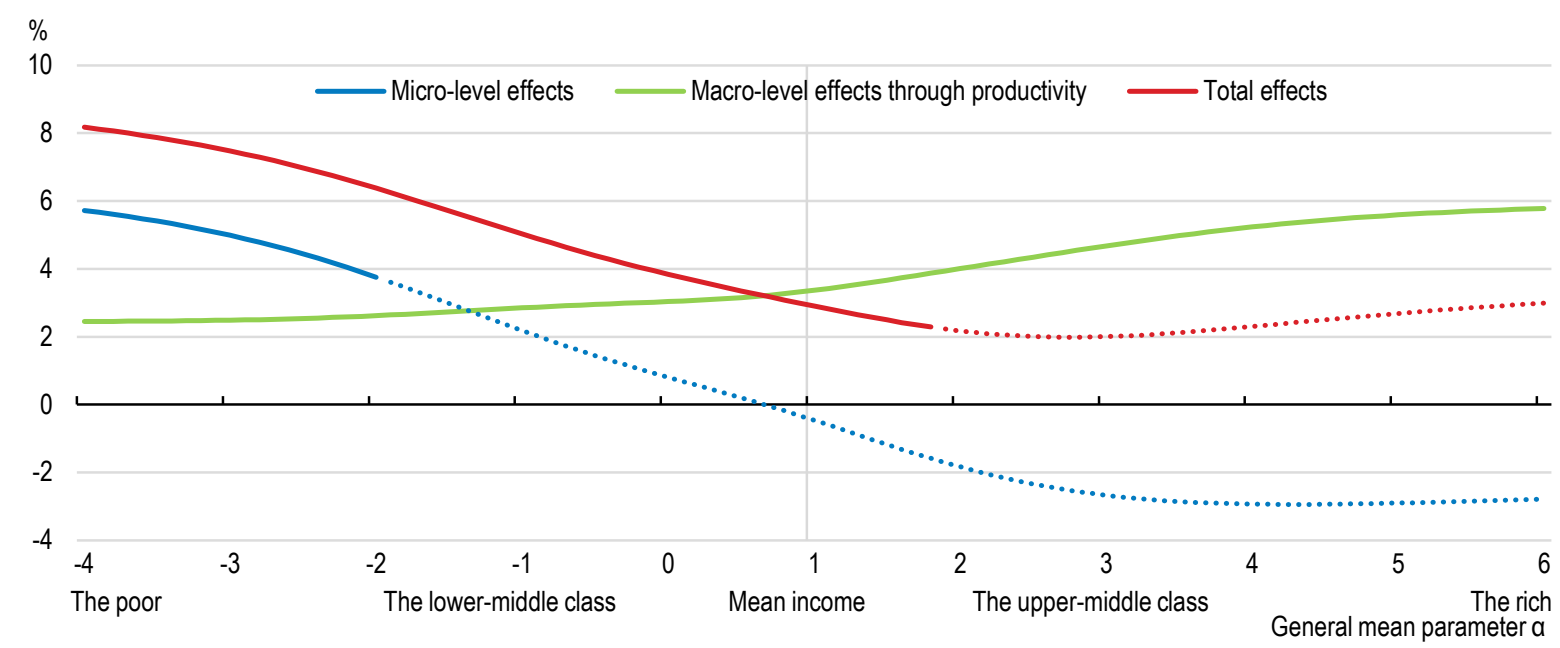

How to read this figure: An increase in government spending on education (in per cent of GDP) by 1 percentage point is estimated to increase household disposable incomes by $2-8 \%$ on average from the poor to the middle class. This total effect can be decomposed along a micro-level effect and macro-level effect through labour productivity. See Box 2 for details of the empirical approach and the definition of the effects. Non-significant estimates (at the $10 \%$ level) are indicated by dots on general mean curves.

\section{Technological progress and globalisation}

34. Higher spending on R\&D is found to lift household incomes across the distribution, with a slightly stronger effect on the rich (Figure 17). Income gains from innovation activity, when the latter is proxied by the number of patent applications (measured on a per-capita basis), are found to be comparatively more unequally distributed: they lift household incomes in the middle class and, slightly more so, among the rich, but not household incomes in the lower-half the distribution (Figure 18). Estimated household income effects are in both cases channelled through disequalising reform-driven increases in labour productivity. However, the magnitude of such effects is small, which implies that policy changes in this area are unlikely to trigger a significant increase in income inequality, taking the estimates at face value.

35. These results are qualitatively consistent with previous empirical studies that highlighted a significant technology-driven disequalising impact and could reflect increasing wage dispersion via mechanisms such as skill-biased technological change. ${ }^{38}$ However, in the absence of significant microlevel effects from patent applications, the results do not provide much support to the argument that poorly designed IPR system may have the perverse effect of precluding some people from enjoying the benefits of innovation; for instance by artificially raising prices at the expense of consumers and the benefit of IPR owners (Stiglitz, 2015).

38. Autor et al. (2006), Goos et al. (2009) and OECD (2011a), Braconier and Ruiz-Valenzuela (2014), Johansson and Olaberria (2014). 
ECO/WKP(2016)66

Figure 17. Effects of an increase in general spending on R\&D on household disposable incomes

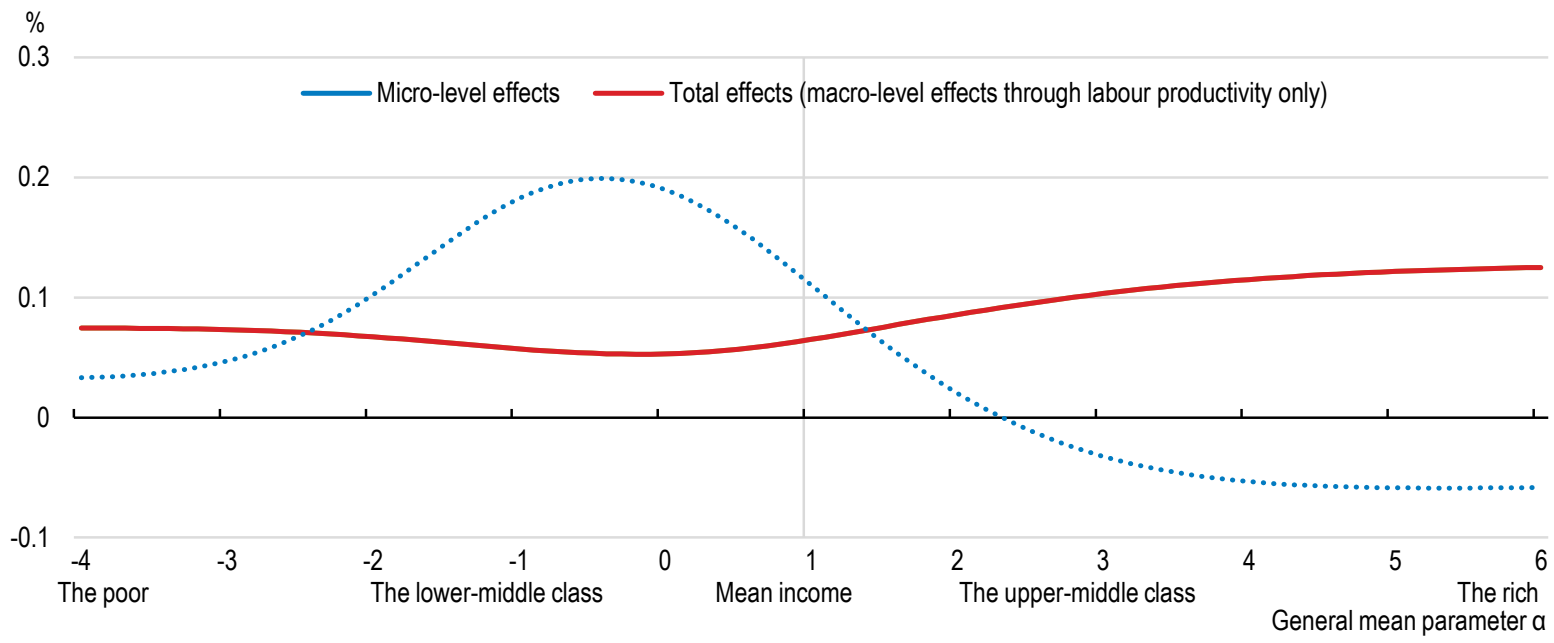

How to read this figure: An increase in general spending on R\&D (in per cent of GDP) by $1 \%$ is estimated to increase household disposable incomes by $0.05-0.13 \%$ across the income distribution with the largest effect among the rich. This total effect comprises only the macro-level effect through labour productivity since the micro-level effect is insignificant for all income groups. See Box 2 for details of the empirical approach and the definition of the effects. Non-significant estimates (at the $10 \%$ level) are indicated by dots on general mean curves.

Figure 18. Effects of an increase in patent applications on household disposable incomes

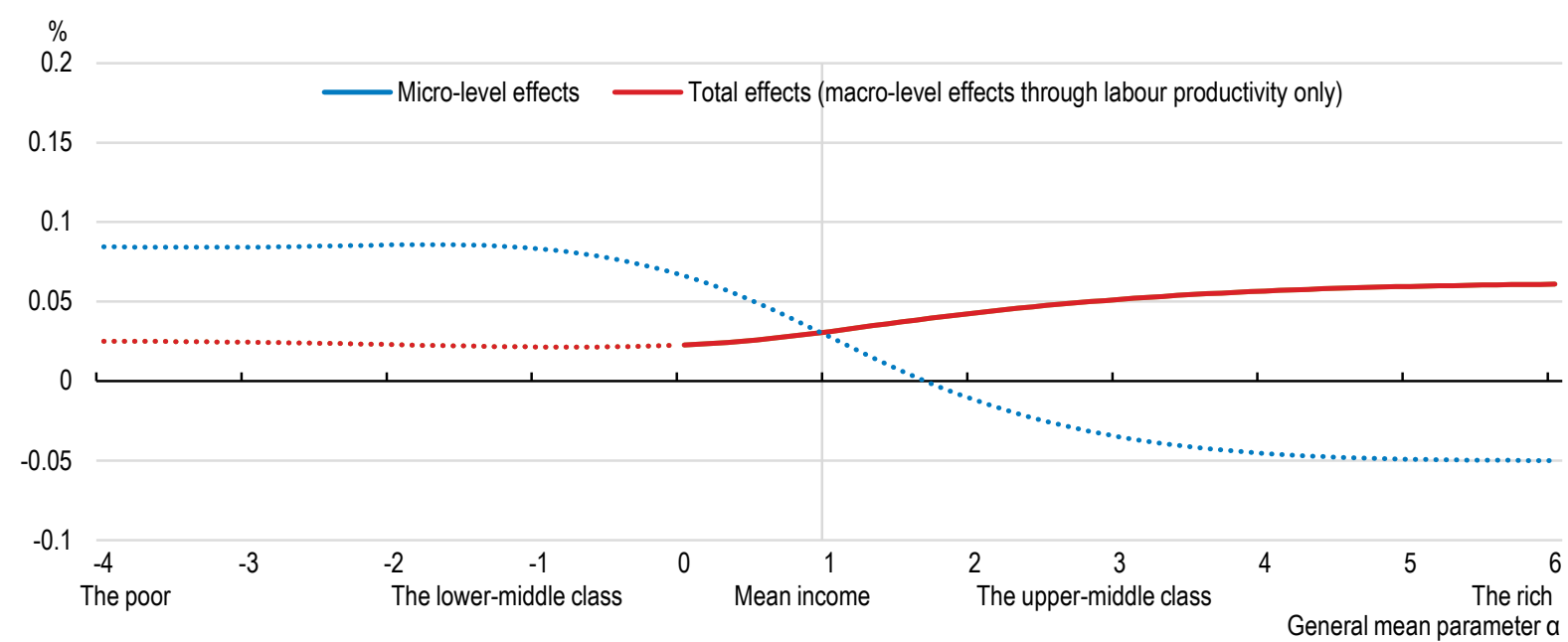

How to read this figure: An increase in the number of patent applications (per capita) by $1 \%$ is estimated to increase household disposable incomes by $0.02-0.06 \%$ on average from the median to the most affluent households. This total effect comprises only the macro-level effect through labour productivity since the micro-level effect is insignificant for all income groups. See Box 2 for details of the empirical approach and the definition of the effects. Non-significant estimates (at the $10 \%$ level) are indicated by dots on general mean curves.

\subsection{Product market regulation}

36. Easing regulation in transport and network industries is found to lift household incomes across the whole distribution (Figure 19). Total household income effects reflect two macro-level distributionnally-offsetting effects: higher labour productivity, which tends to benefit the most affluent 
households disproportionately, and higher labour utilisation, which tends to benefit households at large, except the rich, for which the impact becomes insignificant. Overall, these two effects leave the income distribution almost unchanged, even though there is some evidence of a slight increase in the income divide between the middle class and rich households. This finding is in line with previous evidence on the ambiguous impact of product market regulation on disposable income inequality. ${ }^{39}$ This is because reformdriven employment gains ${ }^{40}$ may be at least partly offset by higher wage dispersion, as more intense product market competition tends to reduce the bargaining power of workers. The results in this section tend to confirm this view. Taken at face value, this would imply that product market reforms entail little trade-off between efficiency and equity objectives.

\section{Figure 19. Effects of a reduction in regulation in network industries on household disposable incomes}

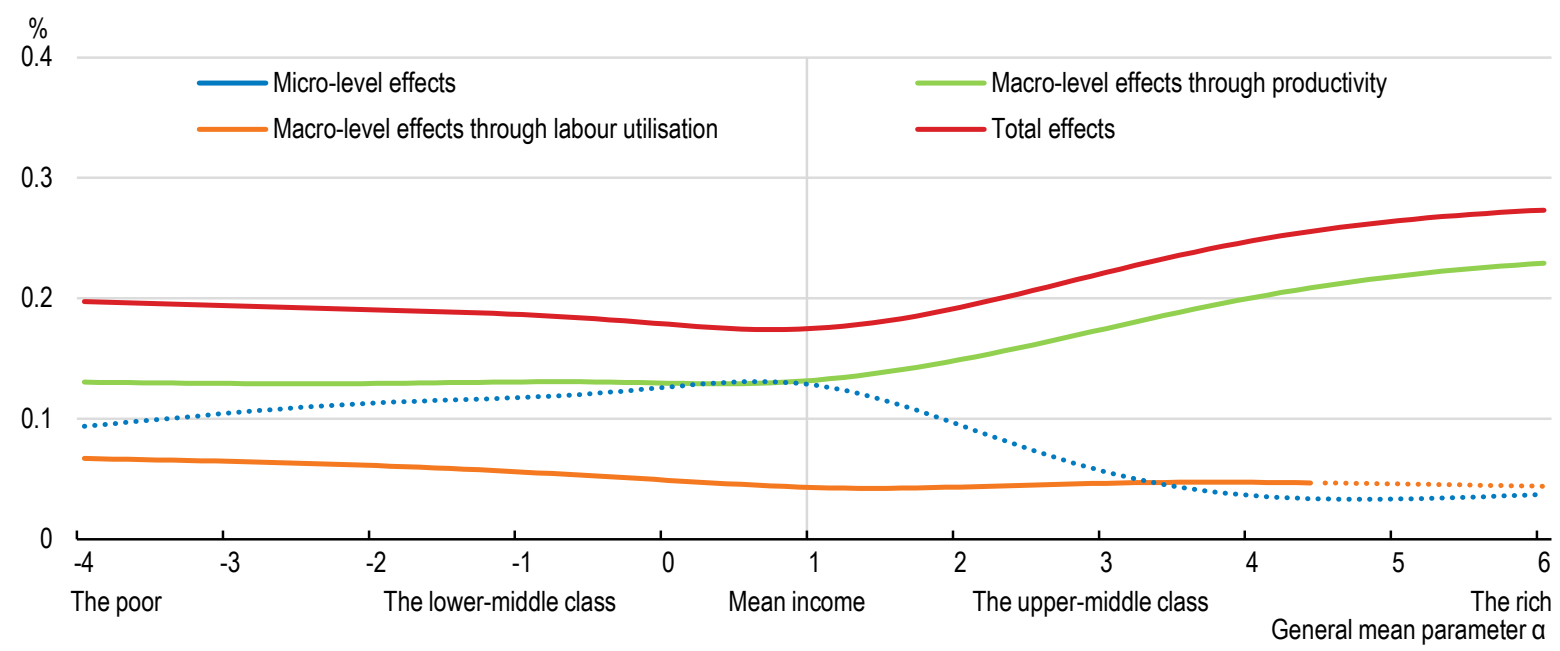

How to read this figure: A reduction in regulation in network industries (ETCR aggregate, index $0-6$ ) by $1 \%$ is estimated to increase household disposable incomes by around $0.2 \%$ on average across the distribution. This total effect can be decomposed along macrolevel effects through labour productivity and labour utilisation. The micro-level effect is insignificant for all income groups and thus not included in the total effect. See Box 2 for details of the empirical approach and the definition of the effects. Non-significant estimates (at the $10 \%$ level) are indicated by dots on general mean curves.

\subsection{Financial sector}

37. Increasing the size of the financial sector, as measured by the share of value added associated with financial services in GDP, is found to reduce household incomes at the bottom of the distribution (Figure 20), implying widening income inequality. The estimates are driven by micro-level effects, while macro-level effects through changes in labour productivity are not significant. This result is in line with recent empirical findings on the adverse distributional effects of finance, which suggests that the long-term costs from credit overexpansion fall disproportionately on vulnerable households by slowing their income growth through capital misallocation and greater instability (Cournède et al., 2015). While deepening financial markets allows credit constrained and low income households to better smooth their consumption, excessive financial expansion is not likely to raise long-term growth but is likely to raise inequality.

39. OECD, (2015); Guadalupe, (2007); Koske et al., (2012). Causa et al. (2015) found equalising effects from product market reforms. However, this is likely to reflect the absence of any significant effect on labour productivity in their estimates, contrary to those reported here.

40. Bassanini and Duval (2006); Nicoletti and Scarpetta, (2005); Fiori et al. (2007); Nicoletti et al. (2001). 
Figure 20. Effects of an increase in value added of finance on household disposable incomes

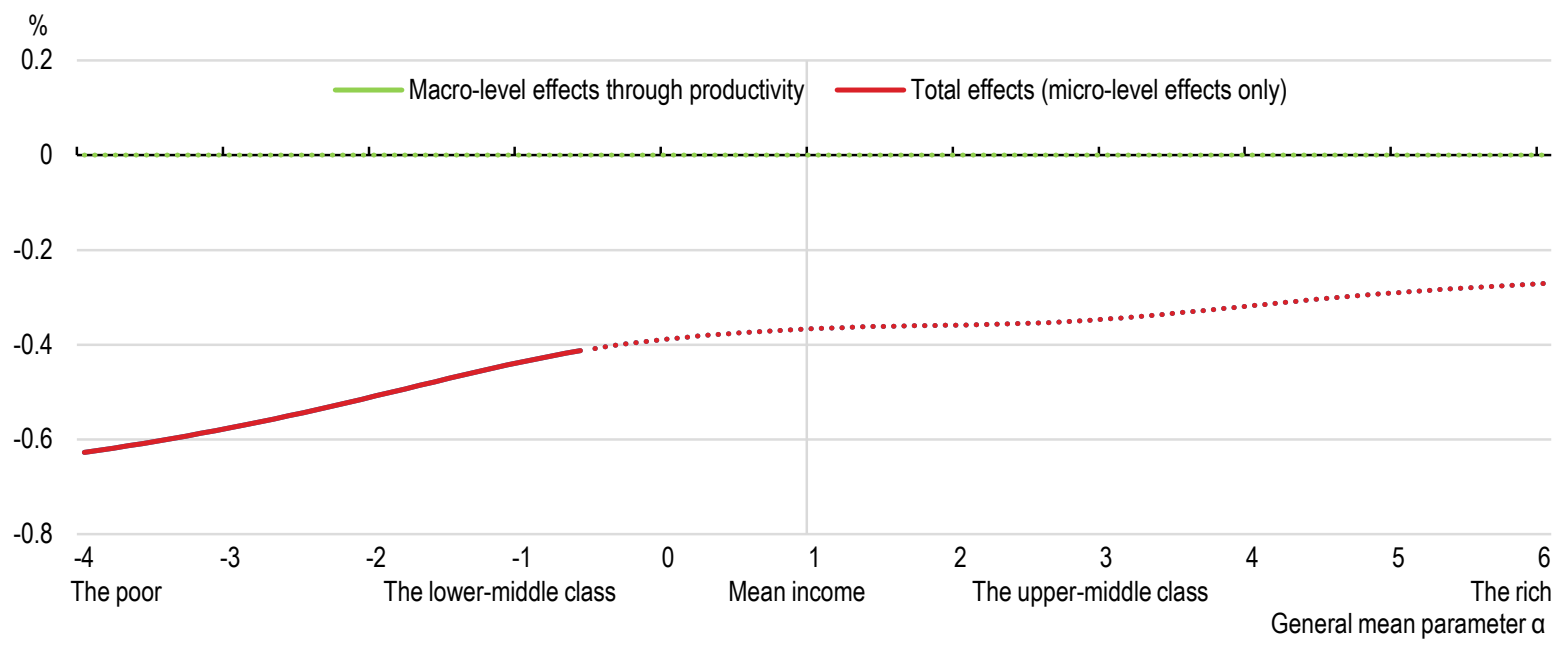

How to read this figure: An increase in value added for the financial sector (in per cent of GDP) by $1 \%$ is estimated to decrease household disposable incomes by $0.4-0.6 \%$ on average among the lower-middle class and the poor. This total effect comprises only the micro-level effect since the macro-level effect on labour productivity is insignificant and thus set to zero. See Box 2 for details of the empirical approach and the definition of the effects. Non-significant estimates (at the $10 \%$ level) are indicated by dots on general mean curves.

38. Overall, the results reported in this paper are robust to alternative specifications or econometric techniques. The Appendix provides a robustness analysis of the policy estimates discussed in the core of the paper. Hermansen at al. (2016) include a robustness analysis of the estimates of growth and its sources on household incomes across the distribution.

\section{Policy synergies and trade-offs between growth and equity}

39. In order to illustrate and quantify policy findings, empirical results can be used with a view to tentatively comparing reforms in terms of their respective effects on growth and income inequality (Tables 1-3). This illustration is produced by taking the estimates at face value and as a result clearly implies a cautious interpretation. The exercise proceeds as follows (see Appendix for details):

- The estimates are used to calibrate the reforms on the following policy targets: i) $1 \%$ long-term increase in either labour productivity or labour utilisation (Table 1), ii) $1 \%$ long-term increase in mean household income (Table 2). The tables present the size of these illustrative reform scenarios, as measured by the required change in associated policy parameters. The simulations are also presented for a one-standard deviation change in each of the policy indicators (Table 3). ${ }^{41}$

- For each reform scenario, Tables 1 to 3 report: i) growth effects (i.e. effects on labour productivity and labour utilisation), ii) mean household disposable income effects, and iii) income inequality effects.

40. Income inequality is measured by the Atkinson inequality index computed for two benchmark cases of inequality aversion (as governed by the parameter $\alpha$ ): 1) weak inequality aversion, i.e. emphasis on the middle class $(\alpha=0.5)$ - equivalent to the assessment based on the Gini coefficient, and 2) strong

41. The one-standard deviation scenario provides some illustrative order of magnitude of required policy changes. 
inequality aversion, i.e. emphasis on the "poor" $(\alpha=-4)$. This is complemented by a measure of tail inequality, simply defined as the income gap between the rich $(\alpha=6)$ and the poor $(\alpha=-4){ }^{42}$ The assessment based on tail inequality complements that based on the Atkinson dispersion measure under strong inequality aversion.

41. Unemployment benefit reform can be used to illustrate the reading of these tables. A reduction in average gross replacement rates by roughly 4 percentage points would be required to deliver a $1 \%$ increase in labour utilisation (Table 1). Such reform is also found to deliver an increase in mean household income by $2.3 \%$. But the reform also increases income inequality, especially based on inequality measures that emphasise incomes among the poor, corresponding to strong inequality aversion: indeed, income inequality is found to increase by 0.4 points of the Atkinson inequality index under weak inequality aversion, and by 1.1 points of the Atkinson inequality index under strong inequality aversion. ${ }^{43}$ This is consistent with the tail inequality assessment which shows that the rich would gain significantly more than the poor. A milder reduction in average gross replacement rates, by roughly 1.7 percentage points, would be required to deliver a $1 \%$ increase mean household income (Table 2). Such reform is found to deliver an increase in labour utilisation of $0.4 \%$. Such reform is also found to increase income inequality, although to a lesser extent (by 0.16 points for the Atkinson inequality index under weak inequality aversion, and 0.5 points of the Atkinson inequality index under strong inequality aversion).

42. The magnitude of reform-driven changes in the income gap between the rich and the poor is not reported because in many cases associated reforms have an impact on either only the poor or only the rich in which case the inequality effect is clearly significant but has no robust quantitative counterpart.

43. Figure 1 provides an order of magnitude of associated inequality measures. The Atkinson index is measured on scale 0-100. The OECD average of the Atkinson index for latest available year is 7.96 for weak inequality aversion and 51.6 for strong inequality aversion. 
Table 1. Policy synergies and trade-offs between growth and equity: illustrative reform scenarios (growth target)

\begin{tabular}{|c|c|c|c|c|c|c|c|c|}
\hline \multicolumn{3}{|c|}{ Policy reform } & \multicolumn{2}{|c|}{ Growth effects (\%) } & \multirow{2}{*}{$\begin{array}{c}\begin{array}{c}\text { Mean } \\
\text { income } \\
\text { effect (\%) }\end{array} \\
\begin{array}{c}\text { No } \\
\text { inequality } \\
\text { aversion }\end{array}\end{array}$} & \multicolumn{2}{|c|}{$\begin{array}{l}\text { Income inequality } \\
\text { effect. } \\
\text { Atkinson index }\end{array}$} & \multirow{2}{*}{$\begin{array}{c}\begin{array}{c}\text { Tail income } \\
\text { inequality } \\
\text { effect }\end{array} \\
\begin{array}{c}\text { Income gap } \\
\text { between the } \\
\text { rich and the } \\
\text { poor }^{2}\end{array} \\
\end{array}$} \\
\hline Policy reform area & Policy reform target & $\begin{array}{l}\text { Policy } \\
\text { reform } \\
\text { magnitude }\end{array}$ & $\begin{array}{l}\text { Labour } \\
\text { productivity } \\
\text { (LP) }\end{array}$ & $\begin{array}{l}\text { Labour } \\
\text { utilisation } \\
\text { (LU) }\end{array}$ & & $\begin{array}{c}\text { Weak } \\
\text { inequality } \\
\text { aversion } \\
(\alpha=0.5)\end{array}$ & $\begin{array}{c}\text { Strong } \\
\text { inequality } \\
\text { aversion } \\
(\alpha=-4)\end{array}$ & \\
\hline \multicolumn{9}{|l|}{ Labour market and welfare policies } \\
\hline ALMP spending (\% of GDP) & LU, $1 \%$ & $12.23 \mathrm{pp}$ & - & 1.00 & 0.00 & -2.59 & 0.00 & $=$ \\
\hline Legal retirement age & LU, $1 \%$ & 4.57 years & - & 1.00 & 1.44 & -0.02 & -0.28 & $<$ \\
\hline Family benefits in kind (\% of GDP) & LU, $1 \%$ & $0.48 \mathrm{pp}$ & - & 1.00 & 0.00 & 0.00 & -5.09 & $<$ \\
\hline Excess coverage of collective agreements & LU, $1 \%$ & $-6.52 \mathrm{pp}$ & - & 1.00 & 2.37 & 0.19 & -0.14 & $<$ \\
\hline Wage bargaining coordination (index 1-5) & LU, $1 \%$ & $34.17 \%$ & - & 1.00 & 0.00 & 0.00 & -3.52 & $<$ \\
\hline Minimum relative to median wage & LU, $1 \%$ & $-2.54 \mathrm{pp}$ & - & 1.00 & 0.00 & 0.00 & 0.00 & $=$ \\
\hline \multicolumn{9}{|l|}{ Tax policy } \\
\hline Labour tax wedge (revenue-neutral) & LU, $1 \%$ & -3.59 & - & 1.00 & 1.44 & -0.17 & -0.53 & $<$ \\
\hline \multicolumn{9}{|l|}{ Education } \\
\hline Public spending on education (\% of GDP) & LP, $1 \%$ & $0.26 \mathrm{pp}$ & 1.00 & - & 0.74 & -0.11 & -0.65 & $<$ \\
\hline \multicolumn{9}{|l|}{ Innovation and technology } \\
\hline General spending on R\&D (\% of GDP) & LP, $1 \%$ & $12.05 \%$ & 1.00 & - & 0.78 & 0.09 & -0.06 & $=$ \\
\hline Number of patent applications (per capita) & LP, $1 \%$ & $29.41 \%$ & 1.00 & - & 0.92 & 0.14 & 0.44 & $>$ \\
\hline \multicolumn{9}{|l|}{ Product market regulation } \\
\hline Regulation in transport and network & LP, $1 \%$ & $-6.71 \%$ & 1.00 & 0.23 & 1.17 & 0.00 & -0.07 & $=$ \\
\hline industries (index 0-6) & LU, $1 \%$ & $-29.04 \%$ & 4.33 & 1.00 & 5.08 & 0.01 & -0.31 & \\
\hline
\end{tabular}

1. The Atkinson index is measured on scale $0-100$. Income inequality effects are simulated around the average Atkinson index across OECD countries for latest available year, $A(0.5)=7.96$ and $A(-4)=51.6$.

2. Difference between estimated reform-effect on the rich $(\alpha=6)$ and the poor $(\alpha=-4)$. ">" (“") indicates a larger (smaller) effect for the rich relative to the poor, while " $=$ " indicates no significant difference.

Note: See Appendix for details of the computations. 
Table 2. Policy synergies and trade-offs between growth and equity: illustrative reform scenarios (mean household income target)

\begin{tabular}{|c|c|c|c|c|c|c|c|c|}
\hline \multicolumn{3}{|c|}{ Policy reform } & \multicolumn{2}{|c|}{ Growth effects (\%) } & \multirow{2}{*}{$\begin{array}{c}\begin{array}{c}\text { Mean } \\
\text { income } \\
\text { effect (\%) }\end{array} \\
\begin{array}{c}\text { No } \\
\text { inequality } \\
\text { aversion }\end{array}\end{array}$} & \multicolumn{2}{|c|}{$\begin{array}{l}\text { Income inequality } \\
\text { effect. } \\
\text { Atkinson index }\end{array}$} & \multirow{2}{*}{$\begin{array}{c}\begin{array}{c}\text { Tail income } \\
\text { inequality } \\
\text { effect }\end{array} \\
\text { Income gap } \\
\text { between the } \\
\text { rich and the } \\
\text { poor }^{2}\end{array}$} \\
\hline Policy reform area & Policy reform target & $\begin{array}{l}\text { Policy } \\
\text { reform } \\
\text { magnitude }\end{array}$ & $\begin{array}{l}\text { Labour } \\
\text { productivity } \\
(\text { LP) }\end{array}$ & $\begin{array}{l}\text { Labour } \\
\text { utilisation } \\
\text { (LU) }\end{array}$ & & $\begin{array}{c}\text { Weak } \\
\text { inequality } \\
\text { aversion } \\
(\alpha=0.5)\end{array}$ & $\begin{array}{l}\text { Strong } \\
\text { inequality } \\
\text { aversion } \\
(\alpha=-4)\end{array}$ & \\
\hline \multicolumn{9}{|l|}{ Labour market and welfare policies } \\
\hline Legal retirement age & Mean income, $1 \%$ & 3.18 years & - & 0.70 & 1.00 & -0.02 & -0.19 & $<$ \\
\hline Excess coverage of collective agreements & Mean income, $1 \%$ & $-2.75 \mathrm{pp}$ & - & 0.42 & 1.00 & 0.08 & -0.06 & $<$ \\
\hline \multicolumn{9}{|l|}{ Tax policy } \\
\hline Labour tax wedge (revenue-neutral) & Mean income, $1 \%$ & -2.49 & - & 0.69 & 1.00 & -0.12 & -0.37 & $<$ \\
\hline \multicolumn{9}{|l|}{ Education } \\
\hline Public spending on education (\% of GDP) & Mean income, $1 \%$ & $0.34 \mathrm{pp}$ & 1.34 & - & 1.00 & -0.14 & -0.88 & $<$ \\
\hline \multicolumn{9}{|l|}{ Innovation and technology } \\
\hline Number of patent applications (per capita) & Mean income, $1 \%$ & $32.12 \%$ & 1.09 & - & 1.00 & 0.16 & 0.48 & $>$ \\
\hline \multicolumn{9}{|l|}{ Product market regulation } \\
\hline $\begin{array}{l}\text { Regulation in transport and network industries } \\
\text { (index 0-6) }\end{array}$ & Mean income, $1 \%$ & $-5.71 \%$ & 0.85 & 0.20 & 1.00 & 0.00 & -0.06 & $=$ \\
\hline
\end{tabular}

1. The Atkinson index is measured on scale $0-100$. Income inequality effects are simulated around the average Atkinson index across OECD countries for latest available year,

$A(0.5)=7.96$ and $A(-4)=51.6$.

2. Difference between estimated reform-effect on the rich $(\alpha=6)$ and the poor $(\alpha=-4)$. " $>$ " (" $<$ ") indicates a larger (smaller) effect for the rich relative to the poor, while " $=$ " indicates no significant difference.

Note: See Appendix for details of the computations. 
ECO/WKP(2016)66

Table 3. Policy synergies and trade-offs between growth and equity: illustrative reform scenarios (one standard deviation change in policy)

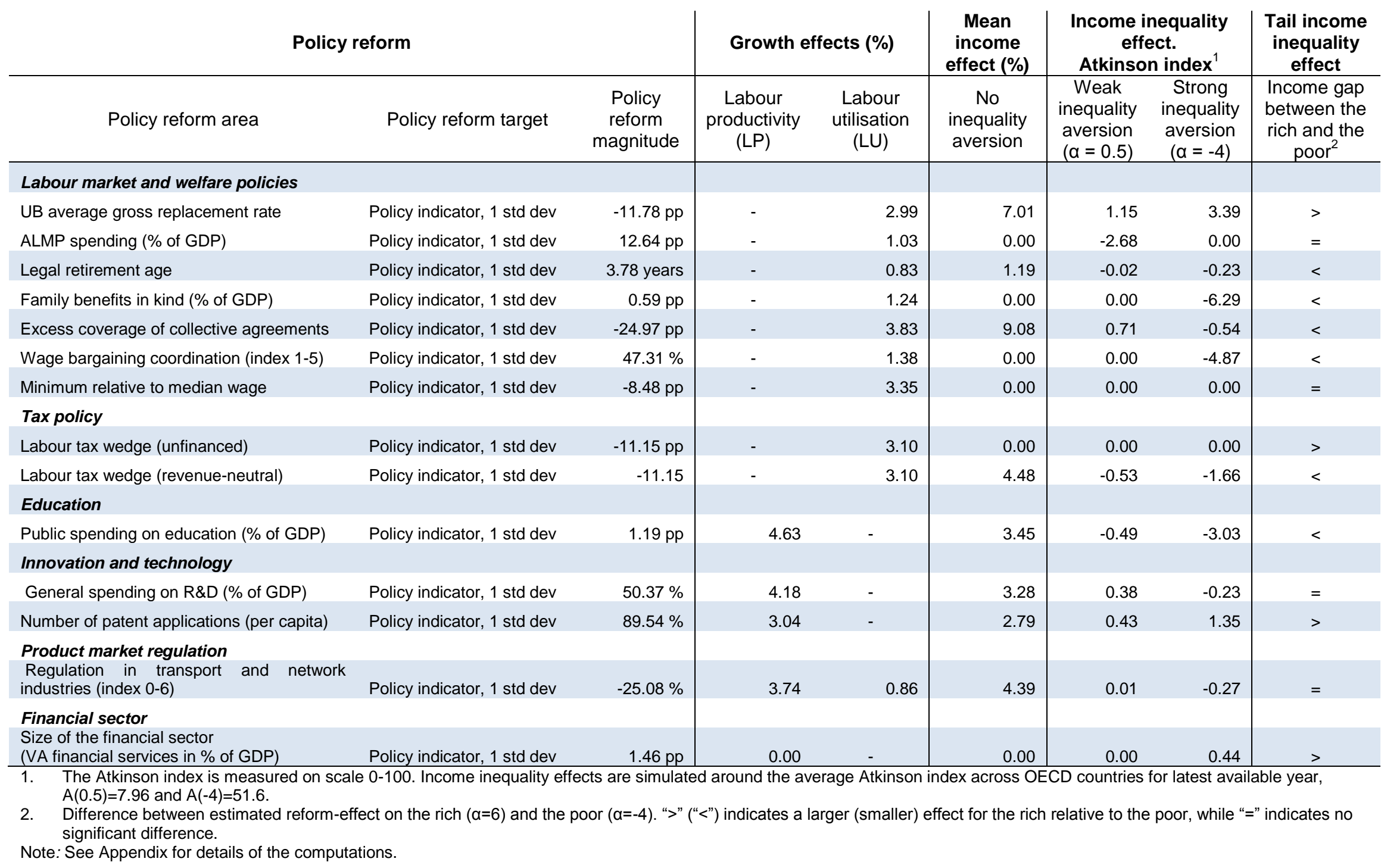


42. The illustrative reform scenarios point to the heterogeneity of the effects of structural reforms on household incomes across the income distribution (Figure 21). The inequality implications from structural reforms depend on how inequality is measured, i.e. on the differential emphasis that different measures attribute to different portions of the income distribution. In turn, this choice partly reflects social preferences, that is, inequality aversion. The main findings on the effect of policies on equity objectives can be summarised as follows, on the basis of OECD cross-country evidence over the last 30 years (Table 4):

- Most structural reforms are broadly distribution-neutral when income inequality is assessed through measures that emphasise the middle class. This corresponds to weak levels of inequality aversion. As a result, most structural reforms are good for the middle class.

- By contrast, a number of structural reforms are no longer distribution-neutral when income inequality is assessed through inequality measures that emphasise relatively more incomes among the poor. This corresponds to higher levels of inequality aversion. Some structural reforms that are good for the middle class can in fact be bad for the poor. As a result, such reforms can be bad for equity under strong inequality aversion but not under weak inequality aversion. Such can be the case of social protection reforms. However, other structural reforms that are good for the middle class can be even better for the poor, hence good for equity under strong inequality aversion but not under weak inequality aversion. Such is the case of increases in public spending on families with children.

- Social protection and labour market reforms raise most of the equity-related challenges:

- Reductions in the generosity of unemployment benefits and social assistance are found to leave behind households in the bottom of the income distribution, hence to increase inequality. This may reflect that past reforms in this area did not promote labour market inclusion even when they generated jobs. At the same time, the evidence suggests that increases in public spending on ALMPs were successful at boosting incomes in the lowermiddle class but not among the poor (Figure 21). This explains why such reforms are found to be good for equity only under weak inequality aversion levels (Table 4). Future reforms could be better designed in this respect: social protection and labour market reforms to remove disincentives to work should be accompanied by reforms to promote quality jobs, preventing in-work poverty and helping people stay in work and advance in their careers. This can be achieved by well-targeted ALMPs and training programmes, including lifelong learning, with a view to raising employability and pay prospects among those with low skills and the long-term unemployed. Overall, the evidence suggests that OECD countries have ample room for reform progress in this area.

- By contrast, increases in legal retirement age are found to deliver income gains to the vast majority of households (Figure 21). This reflects reform-driven increases in older workers employment, with associated income gains taking on board households at the bottom of the distribution. ${ }^{44}$

- Reductions in minimum relative to median wages are associated with rising employment but are not found to trigger a significant change in household disposable income inequality. This is likely to reflect the interplay between rising employment and rising

44. This does not imply that such reforms enhanced the well-being of vulnerable households, as well-being goes well beyond the income dimension (see e.g. the OECD Better Life Initiative). 
wage dispersion, with the two effects offsetting each other when income inequality encompasses inequality between the employed and the non-employed.

- Reforms of collective bargaining institutions may be good or bad for equity, depending on reform design. Phasing out administrative extension of collective agreements and increasing the degree of wage bargaining coordination is found to boost labour market performance and to reduce income inequality. By contrast, the trend decline in union density experienced by many OECD countries over the last decades is found to have raised the income gap between the rich and the poor.

- Reductions in labour taxation tend to widen income inequality and may be bad for equity, in particular when aversion to inequality is strong. This is because such reforms are not found to benefit households in the lower-half of the distribution (Figure 21), even if they generate employment gains. This may reflect that, all else equal, broad-based reductions in labour taxes may have generally resulted in a lower degree of progressivity of the income tax schedule. Reforms in this area can nevertheless be designed to achieve both employment and equity objectives: targeting tax reductions to low-wage earners or increasing earned income tax credits allows for enhancing labour market inclusion and achieving income redistribution without undermining work incentives.

- Reforms to encourage innovation and technical progress benefit relatively more rich than poor households (Figure 21), but the estimated policy-driven rise in inequality is quantitatively moderate. However, the finding of little tension between technology diffusion and income equality may also reflect the tendency for redistribution policies to have at least partially contained the disequalising effect of technology on post taxes and transfer income, on average across the OECD over the period under consideration. This could signal future challenges to redistribution systems and potential trade-offs between growth, equity and fiscal objectives.

- Easing barriers to firm entry and competition in product markets delivers real income gains to all households and such gains are shared equitably (Figure 21). This is driven by higher employment and productivity. These findings would suggest that reforms in this area boost growth without raising trade-offs with equity objectives, irrespective of the level of inequality aversion (Table 4).

- Stepping-up public spending on education, in particular on childcare and early-education facilities, boosts growth and at the same time reduces income inequality, for instance by encouraging women labour market participation, thus raising labour market inclusion. Reforms in this area deliver on both equity and efficiency objectives (Table 4) and public investment on early stages of the education system is thus likely to exhibit a high return. 
Figure 21. Pro-growth policy reforms and household disposable income across the distribution

Reforms standardised to deliver $1 \%$ increase in labour productivity (LP) or labour utilisation (LU)

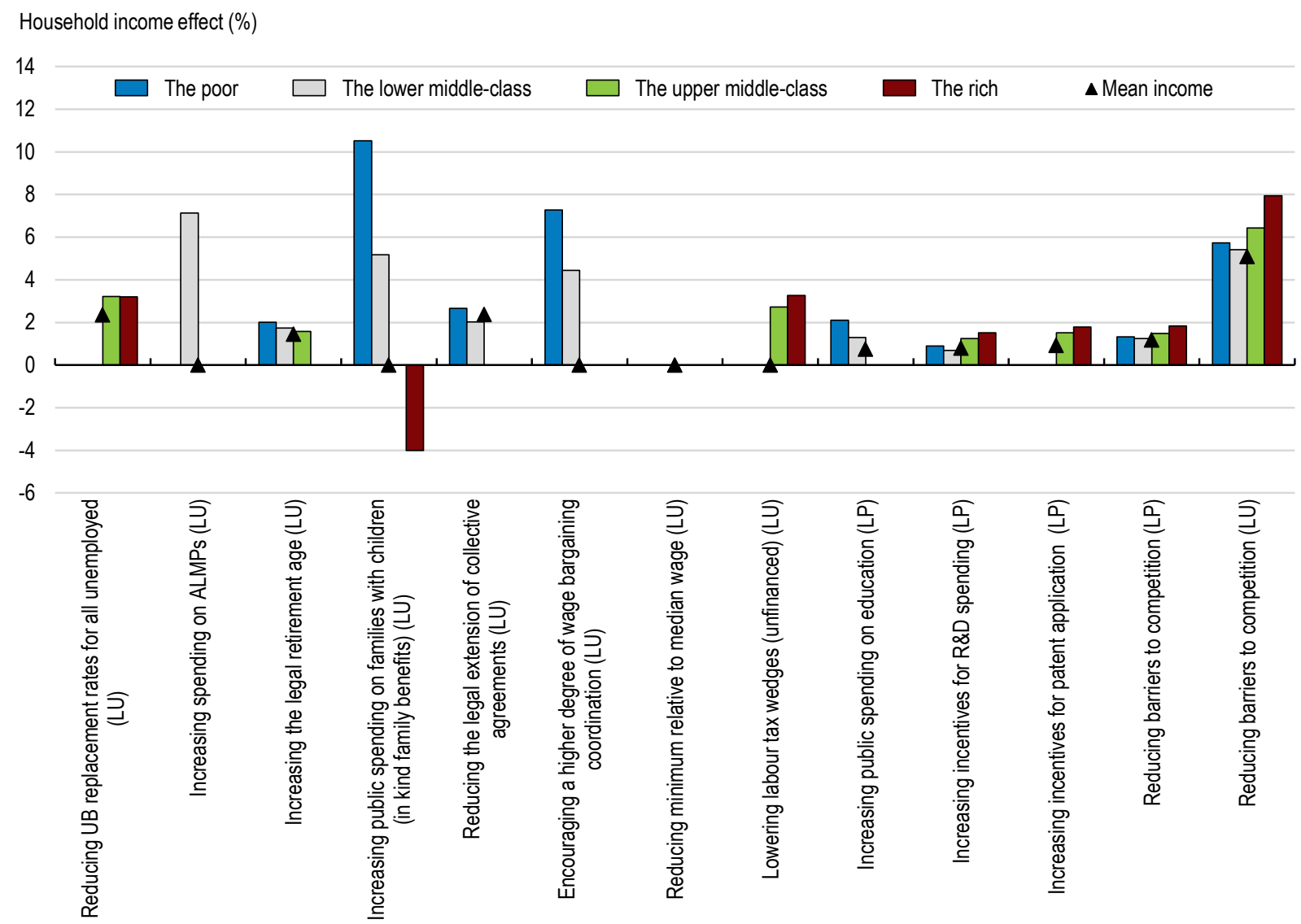

Note: Reform effects across the distribution are quantified by the total household income effects for different income groups corresponding to different values of $\alpha$; the poor $(\alpha=-4)$, the lower middle-class $(\alpha=-1)$, the upper middle-class ( $\alpha=3)$, and the rich ( $\alpha=6)$. The figure also reports reform effects on mean household income $(\alpha=1)$. All policy reforms are standardised to deliver a $1 \%$ increase in labour productivity (LP) or labour utilisation (LU), see text and Table 1. 
Table 4. Policy synergies and tradeoffs between growth and equity

Structural reforms

Effect on equity objectives

\section{Under weak inequality aversion (1) \\ Under strong inequality aversion (2)}

\section{Labour market and welfare policies}

Reducing UB replacement rates for all unemployed

Increasing spending on ALMPs

Increasing the legal retirement age

Increasing public spending on families with children (in kind family benefits)

Reducing the legal extension of collective agreements

Encouraging a higher degree of wage bargaining coordination

Reducing minimum relative to median wage

\section{Tax policy}

Lowering labour tax wedges (unfinanced)

\section{Education}

Increasing public spending on education

\section{Innovation and Technology}

Increasing incentives for R\&D spending

Increasing incentives for patent application

\section{Product market regulation}

Reducing barriers to competition

Bad
Good
Neutral
Neutral
Neutral
Neutral
Neutral
Neutral

Neutral

Neutral

Neutral

Neutral

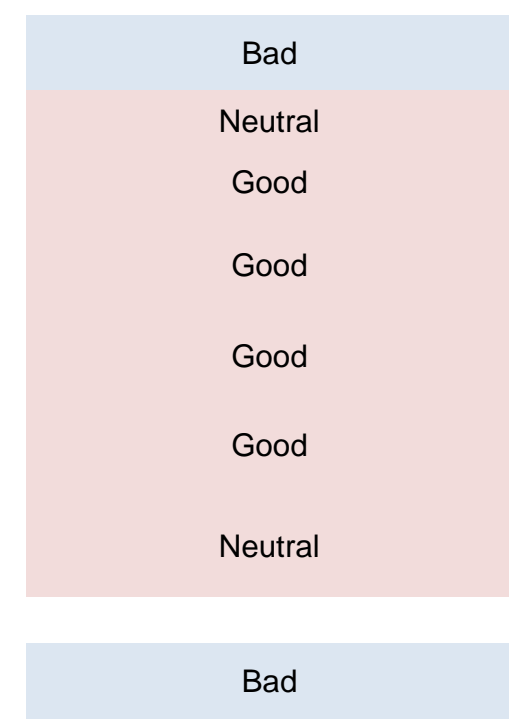

Good

(1) Weak inequality aversion corresponds to assessing changes in inequality based on the Atkinson index with $\alpha=0.5$. This index emphasises the middle of the income distribution and the assessment corresponds to that delivered by the Gini coefficient.

(2) Strong inequality aversion corresponds to assessing changes in inequality based on the Atkinson index with $\alpha=-4$. This is complemented by a tail inequality measure, defined as the income gap between the poor $(\alpha=-4)$ and the rich $(\alpha=6)$.

Note: The effect on equity objectives is identified as "good" when policy reforms reduce inequality; as "bad" when policy reforms increase inequality; and "neutral" when policy reforms have no impact on inequality. The classification is based on the simulations of reforms to deliver $1 \%$ growth in LP or LU (Table 1), and alternatively $1 \%$ mean income growth (Table 2 ) or 1 std dev change (Table 3 ) if macro-level growth effects are not available. The Atkinson index varies on a scale $0-100$. Changes ranging between -0.33 and 0.33 for Atkinson index with $\alpha=0.5$ and between -1 and 1 for Atkinson index with $\alpha=-4$ are considered equivalent to 0 (no changes in inequality). Levels and simulated changes in the Atkinson index are larger for $\alpha=-4$ than $\alpha=0.5$ by construction (see Figure 1 and Appendix), which necessitates the use of different bounds. The chosen bounds reflect that the standard deviation of the Atkinson index across OECD countries is approximately three times larger for $\alpha=-4$ than $\alpha=0.5$. The complexity of the computation of policy reform effects prevents a proper in-sample assessment of uncertainty based on standard statistical methods. Instead simple bounds, roughly in line with estimates in Biewen and Jenkins (2006) for $\alpha=0.5$, have been chosen for transparency. The strong inequality aversion criterion also takes into account the effect of each reform on tail inequality, in which case a "bad" ("good") effect is identified when the income of the poor declines (increases) significantly relative to the income of the rich (see Tables 1-3). 


\section{REFERENCES}

Andrews, D. and F. Cingano (2012), "Public Policy and Resource Allocation: Evidence from Firms in OECD Countries", OECD Economics Department Working Papers, No. 996, OECD Publishing, Paris, http://dx.doi.org/10.1787/5k9158wpf727-en

Atkinson, A.B. (2015), Inequality: What can be done?, Harvard University Press.

Atkinson, A.B. (1970), "On the measurement of inequality", Journal of Economic Theory, Vol. 2/3, pp. 244-263.

Autor, D.H., W.R. Kerr and A. Kugler (2007), "Do Employment Protections Reduce Productivity? Evidence from U.S. States", Economic Journal, Vol. 117, pp. F189-F217.

Autor, D.H., L.F. Katz and M.S. Kearney (2006), "The Polarization of the U.S. Labor Market", American Economic Review, Papers and Proceedings, Vol. 96/2, pp. 189-194.

Bassanini, A. and R. Duval (2006), "Employment Patterns in OECD Countries: Reassessing the Role of Policies and Institutions", OECD Economics Department Working Papers, No. 486, OECD Publishing, Paris, http://dx.doi.org/10.1787/702031136412

Bassanini, A., L. Nunziata and D. Venn (2009), "Job Protection Legislation and Productivity Growth in OECD Countries”, Economic Policy, Vol. 24, pp. 349-402.

Bassanini, A. and A. Garnero (2013), "Dismissal Protection and Worker Flows in OECD Countries: Evidence from Cross-Country/Cross-Industry Data", Labour Economics, Vol. 21, pp. 25-41.

Belot, M., J. Boone and J. Van Ours (2007), "Welfare-Improving Employment Protection", Economica, Vol. 74/295, pp. 381-396.

Biewen, M. and S.P. Jenkins (2006), "Variance Estimation for Generalized Entropy and Atkinson Inequality indices: the Complex Survey Data Case", Oxford Bulletin of Economics and Statistics, Vol. 68, pp. 371-383.

Blundell, R.W. and S.R. Bond (1998), "Initial Conditions and Moment Restrictions in Dynamic Panel Data Models", Journal of Econometrics, Vol. 87, pp. 115-143.

Bouis, R. et al. (2012), "The Short-Term Effects from Structural Reforms: An Empirical Analysis", $O E C D$ Economics Department Working Papers, No. 949, OECD Publishing, Paris, http://dx.doi.org/10.1787/5k9csvk4d56d-en

Braconier, H. and J. Ruiz Valenzuela (2014), "Gross Earning Inequalities in OECD Countries and Major Non-member Economies: Determinants and Future Scenarios", OECD Economics Department Working Papers, No. 1139, OECD Publishing, Paris, http://dx.doi.org/10.1787/5jz123k7s8bv-en

Campos, N. F. and J. Nugent (2012), "The Dynamics of the Regulation of Labor in Developing and Developed Countries since 1960", IZA Discussion Paper No. 6881.

Causa, O. and A. Johansson (2009), "Intergenerational Social Mobility in OECD countries", OECD Journal: Economic Studies, Vol. 2010, pp. 1-44.

Causa, O., A. de Serres, and N. Ruiz (2015), "Can Pro-growth Policies Lift All Boats? An Analysis Based on Household Disposable Income", OECD Journal: Economic Studies, Vol. 2015, pp. 227-268, http://dx.doi.org/10.1787/eco_studies-2015-5jrqhbb1t5jb 
Checchi, D. and C. García-Peñalosa (2008), "Labour Market Institutions and Income Inequality", Economic Policy, Vol. 23, pp. 601-649.

Cournède, B., O. Denk and P. Hoeller (2015), "Finance and Inclusive Growth", OECD Economic Policy Papers, No. 14, OECD Publishing, Paris, http://dx.doi.org/10.1787/5js06pbhf28s-en

Fournier, J.-M., A. Johansson and D. Bloch (2016), "The Effect of the Size and the Mix of Public Spending on Growth and Inequality", OECD Economics Department Working Papers, forthcoming, OECD Publishing, Paris.

Égert, B. (2016), "Regulation, institutions and productivity: new macroeconomic evidence from OECD countries", OECD Economics Department Working Papers, forthcoming, OECD Publishing, Paris.

Fiori, G. et al. (2007), "Employment Outcomes and the Interaction between Product and Labor Market Deregulation: Are they Substitutes or Complements?", IZA Discussion Papers, No. 2770.

Foster, J. E. and M. Szekely (2008), "Is Economic Growth Good for the Poor? Tracking Low Incomes Using General Means", International Economic Review, Vol. 49/4, pp.1143-1172.

Foster, J. E., S. Seth, M. Lokshin and Z. Sajaia (2013), A Unified Approach to Measuring Poverty and Inequality: Theory and Practice. The World Bank, Washington.

Gal, P. and A. Theising (2015), "The Macroeconomic Impact of Structural Policies on Labour Market Outcomes in OECD Countries: A Reassessment", OECD Economics Department Working Papers, No. 1271, OECD Publishing, Paris, http://dx.doi.org/10.1787/5jrqc6t8ktjf-en

Goos, M., A. Manning and A. Salomons (2009), "Job Polarization in Europe", American Economic Review, Papers and Proceedings, Vol. 99/2, pp. 58- 63.

Guadalupe, M. (2007), "Product Market Competition, Returns to Skill, and Wage Inequality", Journal of Labor Economics, Vol. 25/3, pp. 439-474.

Hermansen, M., N. Ruiz and O. Causa (2016), "The Distribution of the Growth Dividends", OECD Economics Department Working Papers, No. 1343, OECD Publishing, Paris.

Jaumotte, F. and C. Osorio Buitron (2015), "Inequality and Labour Market Institutions", IMF Staff Discussion Note.

Johannsson, ^ and E. Olaberria (2014), "Long-Term Patterns of Trade and Specialisation", OECD Economics Department Working paper, No. 1136, OECD Publishing, Paris, http://dx.doi.org/10.1787/5jz158tbddbr-en

Koeniger, W. (2005), “Dismissal Costs and Innovation”, Economics Letters, Vol. 88, pp. 79-84.

Korpi, W., (2006), "Power Resources and Employer-centered Approaches in Explanations of Welfare States and Varieties of Capitalism”, World Politics, Vol. 58, pp. 167-206.

Koske, I., J. Fournier, and I. Wanner (2012), "Less Income Inequality and More Growth - Are They Compatible? Part 2. The Distribution of Labour Income", OECD Economics Department Working Papers, No. 925, OECD Publishing, http://dx.doi.org/10.1787/5k9h2975rhhf-en 
Murtin, F., A. de Serres and A. Hijzen (2014), "Unemployment and the Coverage Extension of Collective Wage Agreements", European Economic Review, Vol. 71, pp. 52-66.

Nickell, S. and R. Layard (1999), "Labor Market Institutions and Economic Performance", in O. Ashenfelter and D. Card (eds.), Handbook of Labor Economics, Vol. 3C, pp. 3029-3084.

Nicoletti, G. et al. (2001), "Product and Labour Markets Interactions in OECD Countries", OECD Economics Department Working Papers, No. 312, OECD Publishing, Paris, http://dx.doi.org/10.1787/814240442882

Nicoletti, G. and S. Scarpetta (2005), "Product Market Reforms and Employment in OECD Countries", OECD Economics Department Working Papers, No.472, OECD Publishing, Paris, http://dx.doi.org/10.1787/463767160680

OECD (2015a), Economic Policy Reforms: Going for Growth, OECD Publishing, Paris http://dx.doi.org/10.1787/growth-2015-en

OECD (2015b), In It Together: Why Less Inequality Benefits All, OECD Publishing, http://dx.doi.org/10.1787/9789264235120-en

OECD (2015c), Pensions at a Glance, OECD Publishing, Paris, http://dx.doi.org/10.1787/pension_glance2015-en

OECD (2015d), Employment Outlook, OECD Publishing, Paris, http://dx.doi.org/10.1787/empl_outlook2015-en

OECD (2011a), Divided We Stand: Why Inequality Keeps Rising, OECD Publishing, http://dx.doi.org/10.1787/9789264119536-en

OECD (2011b), How's Life? Measuring Well-being, OECD Publishing, Paris, http://dx.doi.org/10.1787/9789264121164-en

OECD (2008), Growing Unequal? Income Distribution and Poverty in OECD Countries, OECD Publishing, Paris, http://dx.doi.org/10.1787/9789264044197-en

OECD (2004), Employment Outlook, OECD Publishing, Paris, http://dx.doi.org/10.1787/empl_outlook2004-en

Ostry, J. D., A. Berg, and C. G. Tsangarides (2014), "Redistribution, Inequality and Growth", IMF Staff Discussion Note, No. SDN/14/02.

Ruiz, N. and N. Woloszko (2015), "What Do Household Surveys Suggest about the Top 1\% Incomes and Inequality in OECD Countries?", OECD Economics Department Working Papers, No. 1265, OECD Publishing, Paris, http://dx.doi.org/10.1787/5jrs556f36zt-en

Stiglitz, J. (2015), Rewriting the Rules of the American Economy: An Agenda for Growth and Shared Prosperity.

Villanueva, E. (2015), "Employment and Wage Effects of Extending Collective Bargaining Agreements", IZA World of Labor 2015, No. 136.

Voitchovsky, S. (2005), "Does the Profile of Income Inequality Matter for Economic Growth?”, Journal of Economic Growth, Vol. 10, pp. 273-296. 


\section{APPENDIX: ADDITIONAL MATERIAL ON THE EMPIRICAL FRAMEWORK}

1. This appendix documents the computation of total household income policy effects presented in Box 2 and illustrated in Figures 4-20 of the paper (Section A.1). It delivers robustness analysis of the policy effects (Section A.2). It also provides details on the policy reform simulations presented in Tables 13 of the paper (Section A.3). The final part of this appendix provides a detailed overview of the crosscountry time series coverage underlying the empirical analysis and descriptive statistics of policy indicators (Section A.4).

\section{A.1. Defining total household income policy effects in a combined macro-micro approach}

2. The objective is to obtain estimates of total household income effects from changes in policies, including growth effects through labour productivity and labour utilisation. Household income is measured for different income groups using the general mean $\mu_{\alpha}$, where $\alpha$ is the order of the general mean. Policy effects are quantified in terms of elasticities and semi-elasticities, i.e:

$$
\begin{aligned}
& E_{\mu_{\alpha}, Z}=\frac{d \mu_{\alpha}}{d Z} \frac{Z}{\mu_{\alpha}}=\frac{d \ln \mu_{\alpha}}{d \ln Z} \\
& S_{\mu_{\alpha}, Z}=\frac{d \mu_{\alpha}}{d Z} \frac{1}{\mu_{\alpha}}=\frac{d \ln \mu_{\alpha}}{d Z}
\end{aligned}
$$

where household income $\mu_{\alpha}$ is expressed in USD constant prices and constant PPP, and $Z$ is a policy variable. The elasticity is the preferred measure for policies such as product market regulation for which a $1 \%$ change in the index is relatively easy to interpret. For other policies, like unemployment benefits replacement rates, the semi-elasticity is preferred since a 1 percentage point increase is a natural change to consider.

3. The effect of policy $Z$ on household income is decomposed in three terms: i) a macro effect through changes in labour productivity, ii) a macro effect through changes in labour utilisation, and iii) a micro effect for given labour productivity and given labour utilisation. The elasticities and semi-elasticities can therefore be decomposed in the following way:

$$
\begin{aligned}
& E_{\mu_{\alpha}, Z}=\frac{d \ln \mu_{\alpha}}{d \ln Z}=\frac{d \ln \mu_{\alpha}}{d \ln L P} \frac{d \ln L P}{d \ln Z}+\frac{d \ln \mu_{\alpha}}{d \ln L U} \frac{d \ln L U}{d \ln Z}+\frac{\partial \ln \mu_{\alpha}}{\partial \ln Z} \\
& S_{\mu_{\alpha}, Z}=\frac{d \ln \mu_{\alpha}}{d Z}=\frac{d \ln \mu_{\alpha}}{d \ln L P} \frac{d \ln L P}{d Z}+\frac{d \ln \mu_{\alpha}}{d \ln L U} \frac{d \ln L U}{d Z}+\frac{\partial \ln \mu_{\alpha}}{\partial Z}
\end{aligned}
$$

Obtaining estimates for all three terms involves several steps documented in the following subsections.

\section{Step 1: Micro policy effects: estimating policy effects across the income distribution}

4. The empirical model to obtain policy effects on household incomes across the distribution takes the following form:

$$
\begin{gathered}
\ln \mu_{\alpha}\left(x_{i t}\right)=\beta_{0, \alpha}+\beta_{1, \alpha} \ln \mu_{\alpha}\left(x_{i t-1}\right)+\beta_{2, \alpha} \ln L P_{i t}+\beta_{3, \alpha} \ln L P_{i t-1}+\beta_{4, \alpha} \ln L U_{i t}+\beta_{5, \alpha} \ln L U_{i t-1} \\
+\beta_{6, \alpha}[\ln ] Z_{i t-1}+\beta_{7, \alpha} N X_{i t}+\gamma_{t}+\eta_{i}+\varepsilon_{i t}
\end{gathered}
$$


where $\mu_{\alpha}$ is household income in a given portion of the distribution, $L P$ is labour productivity, $L U$ is labour utilisation, and $Z$ is a policy variable, which may or may not be log transformed (see below). The long-run relationship between household income and the policy variable is given by:

$$
\ln \mu_{\alpha}(x)=\beta_{0, \alpha}+\underbrace{\frac{\beta_{2, \alpha}+\beta_{3, \alpha}}{1-\beta_{1, \alpha}}}_{=\pi_{L P, \alpha, Z}} \ln L P+\underbrace{\frac{\beta_{4, \alpha}+\beta_{5, \alpha}}{1-\beta_{1, \alpha}}}_{=\pi_{L U, \alpha, Z}} \ln L U+\underbrace{\frac{\beta_{6, \alpha}}{1-\beta_{1, \alpha}}}_{=\mu_{\mu_{\alpha, Z}, \alpha}}[\ln ] Z
$$

The long-run relationship involves non-linear functions of the estimated parameters. Standard errors for $\pi_{L P, \alpha, Z}, \pi_{L U, \alpha, Z}$, and $D_{\mu_{\alpha}, Z}$ are therefore obtained by the delta method.

\section{Step 2: Macro policy effects: building on empirical estimates from companion studies}

5. The quantitative effect of policies on labour productivity is obtained from Égert (2016) and collected in Table A.1. Labour productivity is defined as GDP per worker and estimates reported as elasticities or semi-elasticities since the dependent variable and some of the policy variables are log transformed. For example, a $1 \%$ increase in the stringency of product market regulation in network industries is estimated to reduce labour productivity by $0.149 \%$.

Table A1. Macroeconomic estimates of policy effects on labour productivity

Policy

Transformation

Estimate

\begin{tabular}{lcr}
\hline Employment protection legislation (EPL, regular contracts) & $\log$ & 0 \\
Government expenditure on education (in \% of GDP) & no & 0.039 \\
General expenditure on R\&D (in \% of GDP) & $\log$ & 0.083 \\
Patent applications filed under the PCT (per capita) & $\log$ & 0.034 \\
Energy, transport and communication regulation (ETCR, aggregate) & -0.149 \\
Value added of financial and insurance activities (in \% of GDP) & no \\
\hline
\end{tabular}

Note: Labour productivity is defined as GDP per worker and has been log-transformed. Estimates for log-transformed policy variables are interpreted as elasticities, and for untransformed policy variables as semi-elasticities. Insignificant effects are set to zero. The estimates for EPL, government expenditure on education, and value added of finance are not presented in Egert (2016), but have been specially produced for this paper.

Source: Égert (2016).

6. Quantitative effects of policies on labour utilisation are taken from Gal and Theising (2015) and collected in Table A.2. In this case, neither the dependent variable nor the policy variable is logtransformed. Again, taking the example of product market regulation, an increase in the stringency of product market regulation in network industries by one index point (on a scale from 0 to 6 ) is estimated to reduce the employment rate by 1.1 percentage points. The dependent variable in Gal and Theising (2015) is the employment rate $(E R)$, defined as employment in number of workers $(E)$ relative to the working age population (age 15-64) (PWA). The concept of labour utilisation applied in the current paper is defined as employment relative to the full population. An adjustment is therefore required to apply Gal and Theising's estimates. Formally, the two concepts are related in the following way:

$$
L U=\frac{E}{P}=\frac{E}{P W A} \frac{P W A}{P}=E R \frac{P W A}{P}
$$

Log transforming and taking derivatives yields

$$
\frac{d \ln L U}{d Z}=\frac{d \ln E R}{d Z}+\frac{d \ln \left(\frac{P W A}{P}\right)}{d Z}
$$


In the following, the policy effect on the share of the working-age population in total population (i.e. the latter term of the above equation) will be assumed to be null. Since this is a purely demographic term, this should not be a critical assumption.

Table A2. Macroeconomic estimates of policy effects on the employment rate

Policy

Unemployment benefit replacement rate (gross, average)

Unemployment benefit replacement rate for long-term unemployed (net, $60^{\text {th }}$ month of benefit receipt)

ALMP spending (in \% of GDP per capita, trend from HP-filter)

Employment protection legislation (EPL, regular contracts)

Excess coverage of collective agreements (bargaining coverage less union density)

Wage bargaining coordination

Minimum wage (in \% of median wage)

Labour tax wedge (one earner couple with 2 children)

Government expenditure on education (in \% of GDP)

Energy, transport and communication regulation (ETCR, aggregate)

\section{Results only available for demographic subgroups}

Legal retirement age. Elderly, age 55-64
Estimate

Transformation

\begin{tabular}{rr} 
no & -0.177 \\
no & 0 \\
no & 0.057 \\
no & 0 \\
\hline no & -0.107 \\
no & 0.717 \\
no & -0.275 \\
\hline no & -0.194 \\
\hline no & 0 \\
\hline no & -1.127
\end{tabular}

Government spending on family benefits in-kind (in \% of GDP).

Prime age women, age 25-54

Note: The employment rate is defined as employment in number of workers relative to the working age population (age 15-64) (scale $0-100$ ). Estimates are interpreted as marginal effects of a change in the level of the untransformed policy variables (not elasticities). Insignificant effects are set to zero. The estimates for UB replacement rate for long-term unemployed and government expenditure on education are not presented in Gal and Theising (2015), but have been specially produced for this paper.

Source: Gal and Theising (2015).

7. Égert (2016) log-transforms labour productivity and some policy variables, whereas Gal and Theising (2015) leave both the employment rate and policy variables untransformed - as mentioned above. Combining the two sets of results therefore requires harmonising variable transformations, with a different adjustment depending on whether policy effects are expressed as elasticities or semi-elasticities (Table A3). When needed, average values for the employment rate and policy variables across countries in year 2011/12 are applied. ${ }^{45}$

Table A3. Applied adjustments of macroeconomic estimates

Available estimate

Applied adjustment

Elasticity Semi-elasticity

45. In theory, one could also use the average across all country/year observations in-sample. In practice, the two approaches give very similar results. The largest difference occurs in the case of network industries regulation: the policy elasticity of labour utilisation is -0.034 when applying the $2011 / 12$ cross-country average and -0.048 when applying the in-sample average. 


\begin{tabular}{lccc}
\hline $\begin{array}{l}\text { Labour } \\
\text { productivity }\end{array}$ & $\theta=\frac{d \ln L P}{d \ln Z}$ & $\varepsilon_{L P, Z}=\frac{d \ln L P}{d \ln Z}=\theta$ & $\sigma_{L P, Z}=\frac{d \ln L P}{d Z}=\frac{d \ln L P}{d \ln Z} \frac{1}{Z}=\theta \frac{1}{Z}$ \\
& $\vartheta=\frac{d \ln L P}{d Z}$ & $\varepsilon_{L P, Z}=\frac{d \ln L P}{d \ln Z}=\frac{d \ln L P}{d Z} Z=\vartheta Z$ & $\sigma_{L P, Z}=\frac{d \ln L P}{d Z}=\vartheta$ \\
\hline $\begin{array}{l}\text { Labour } \\
\text { utilisation }\end{array}$ & $\rho=\frac{d E R}{d Z}$ & $\varepsilon_{L U, Z}=\frac{d \ln L U}{d \ln Z}=\frac{d E R}{d Z} \frac{Z}{E R}=\rho \frac{Z}{E R}$ & $\sigma_{L U, Z}=\frac{d \ln L U}{d Z}=\frac{d E R}{d Z} \frac{1}{E R}=\rho \frac{1}{E R}$
\end{tabular}

Note: Available estimate refers to the macroeconomic estimates of policy reforms on labour productivity and the employment rate in Égert (2016) and Gal and Theising (2015), respectively.

8. For a few policy variables, the macroeconomic labour utilisation effects have only been found for demographic subgroups. This is the case for the legal pension age (elderly, age 55-64) and government spending on family in-kind benefits (prime age women, age 25-54). To apply these estimates and derive aggregate employment effects, a decomposition of total labour utilisation into two subgroups $G 1$ and $G 2$ is used:

$$
L U=\frac{E}{P}=\frac{E^{G 1}}{P^{G 1}} \frac{P^{G 1}}{P}+\frac{E^{G 2}}{P^{G 2}} \frac{P^{G 2}}{P}=E R^{G 1} \frac{P^{G 1}}{P}+E R^{G 2} \frac{P^{G 2}}{P}
$$

Where $E^{G l}$ is the number of employed workers in subgroup $G l$ and $P^{G l}$ is the population in subgroup $G 1$. Note that $E=E^{G 1}+E^{G 2}$ and $P=P^{G I}+P^{G 2}$. Taking $\operatorname{logs}$ and the derivative w.r.t. policy $Z$ yields:

$$
\sigma_{L U, Z}=\frac{d \ln L U}{d Z}=\frac{1}{L R U}\left(\frac{d E R^{G 1}}{d Z} \frac{P^{G 1}}{P}+E R^{G 1} \frac{d\left(\frac{P^{G 1}}{P}\right)}{d Z}+\frac{d E R^{G 2}}{d Z} \frac{P^{G 2}}{P}+E R^{G 2} \frac{d\left(\frac{P^{G 2}}{P}\right)}{d Z}\right)
$$

For the legal retirement age, Gal and Theising (2015) find that only elderly (age 55-64) respond to a policy change and since both demographic effects (the policy effects on population shares in the two subgroups) can be assumed negligible, only the first term in the bracket is different from zero. A similar assumption is imposed for family in-kind benefits in the case of prime age women. Average labour utilisation and population shares across countries in the year 2012 are applied in the calculations.

Legal retirement age:

$$
\sigma_{L U, Z}=\frac{1}{L U} \frac{d E R^{55-64}}{d Z} \frac{P^{55-64}}{P}=\frac{1}{46.65} 0.851 \cdot 0.12 \cdot 100 \%=0.22
$$

An increase in the legal retirement age by 1 year is estimated to increase the employment rate for the elderly by 0.851 percentage points. Adjusting this to cover the total population implies that an increase by 1 year is estimated to raise labour utilisation by $0.22 \%$.

Family benefits in kind:

$$
\sigma_{L U, Z}=\frac{1}{L U} \frac{d E R^{25-54, F}}{d Z} \frac{P^{25-54, F}}{P}=\frac{1}{46.65} 4.643 \cdot 0.21 \cdot 100 \%=2.09
$$


An increase in family benefits in kind (in \% of GDP) by 1 percentage point is estimated to increase the employment rate for prime age women by 4.643 percentage points. ${ }^{46}$ Adjusting this to cover the total population implies that an increase by 1 percentage point is estimated to raise labour utilisation by $2.09 \%$

\section{Step 3: Combining micro and macro policy estimates to obtain total household income effects}

9. Combining steps 1 and 2 allows for deriving an estimate of total policy effects on household incomes, including macro effects through productivity and labour utilisation. For policy effects quantified in terms of elasticities, the total effect is given by:

$$
E_{\mu_{\alpha}, Z}=\pi_{L P, \alpha, Z} \varepsilon_{L P, Z}+\pi_{L U, \alpha, Z} \varepsilon_{L U, Z}+D_{\mu_{\alpha}, Z}=\pi_{L P, \alpha, Z} \theta+\pi_{L U, \alpha, Z} \rho \frac{Z}{E R}+D_{\mu_{\alpha}, Z}
$$

where relevant coefficients the have been defined above. The first term is the macro effect through labour productivity, which is the product of the effect of labour productivity on household income and the effect of policy $Z$ on labour productivity. Note that the effects of labour productivity and labour utilisation on income are conditional on policy $Z$, as indicated by subscripts. The former varies across the income distribution (as governed and indicated by the subscript $\alpha$ ), whereas the latter is by definition constant across the income distribution (no $\alpha$ subscript). The second term is the effect through labour utilisation, and in this case the macroeconomic effect is adjusted by the average value of the policy and the employment rate to obtain an elasticity. The third term is the micro policy effect on household income, obtained from the estimation presented in step 1.

Example: Product market regulation in network industries, effect on average household income $(\alpha=1)$

$$
E_{\mu_{1}, Z}=0.89 \cdot(-0.149)+1.25 \cdot(-1.127) \cdot \frac{2.13}{69.15}+0=-0.13-0.04+0=-0.18
$$

A $1 \%$ reduction in the stringency of product market regulation in network industries is estimated to increase average household disposable income by $0.18 \%$. This total effect can be decomposed into a macro effect through labour productivity of $0.13 \%$ and a macro effect through labour utilisation of $0.04 \%$. The estimated micro effect is insignificant and therefore set to zero (see below).

10. For semi-elasticities the total effect is constructed in the following way

$$
S_{\mu_{\alpha}, Z}=\pi_{L P, \alpha, Z} \sigma_{L P, Z}+\pi_{L U, \alpha, Z} \sigma_{L U, Z}+D_{\mu_{\alpha}, Z}=\pi_{L P, \alpha, Z} \theta \frac{1}{Z}+\pi_{L U, \alpha, Z} \rho \frac{1}{E R}+D_{\mu_{\alpha}, Z}
$$

Example: UB replacement rate, effect among the upper-middle class $(\alpha=3)$

$$
S_{\mu_{-8}, Z}=\left(0+1.69 \cdot(-0.177) \frac{1}{69.15}-0.0039\right) \cdot 100 \%=-0.43--0.39=-0.82
$$

A 1 percentage point reduction in the UB average gross replacement rate is estimated to increase household income by $0.82 \%$ in the upper-middle class. This total effect can be decomposed into a macro effect through labour utilisation of $0.43 \%$ and a micro effect of $0.39 \%$.

46. This should only be taken as a standardised way to report the estimated effect. Average spending on family benefits in kind across OECD countries in 2011 was around 1\% of GDP. A 1 percentage point increase thus amounts to an average increase of $100 \%$, which seems an unrealistic policy change. 


\section{Testing the significance of combined macro-micro estimates}

11. The total effects computed above are point estimates, but associated standard errors (i.e. measuring the uncertainty from both macro and micro estimates as well as their covariation) cannot be derived in this setting. This would require the joint macro-micro estimation of a fully integrated model, which is beyond the scope of this paper. As a result, the current approach requires the assumption of full independence between macro and micro estimates. The significance of macro effects is assessed separately and only macro estimates passing the significance test are included, whereas insignificant effects are set to zero (see Table A1 and A2). In practice, for the computation and significance test of the total effect, two cases are considered:

- Micro effects are significant for some household income groups: the total effect is computed as the sum of non-zero macro effects through labour productivity and labour utilisation and the micro effect for all income groups, i.e. general mean parameters (from -4 to 6). The joint significance of the total effect, treating macro estimates $\varepsilon_{L P, Z}$ and $\varepsilon_{L U, Z}$ as exogenous parameters, is assessed by a standard Wald test for nonlinear hypothesis. The null hypothesis becomes:

$$
H_{0}: \hat{\pi}_{L P, \alpha, Z} \varepsilon_{L P, Z}+\widehat{\pi}_{L U, \alpha, Z} \varepsilon_{L R U, Z}+\widehat{D}_{\mu_{\alpha}, Z}=0
$$

- Micro effects are insignificant for all income groups: the total effect is computed as the sum of non-zero micro effects through labour productivity and labour utilisation only. In this case, the absence of a significant micro effect regardless of the income group is taken as indicative evidence that the underlying channel is non-existent or too weakly identified to be considered. This is for instance the case for innovation policies ( $\& \& D$ spending and patent applications) for which micro household income effects, that is, in addition to effects via labour productivity, do not seem to correspond to any meaningful economic mechanism. The joint significance of the total effect is in this case also tested by a Wald test, but with the micro effect set to zero:

$$
H_{0}: \hat{\pi}_{L P, \alpha, Z} \varepsilon_{L P, Z}+\hat{\pi}_{L U, \alpha, Z} \varepsilon_{L R U, Z}=0
$$

\section{A.2. Robustness analysis}

12. This section analyses the robustness of estimates of the effects of structural policies on household incomes across the distribution, for given distribution-neutral macro-level effects of structural policies on labour productivity and labour utilisation (see Figure 3 and Box 2). Robustness analysis of structural reform effects on labour productivity and labour utilisation can be found in Gal and Theising (2015) and Egert (2016). Since associated estimates are distribution-neutral, their significance is arguably more important than the specific parameter values for assessing the distributional effects of reforms. ${ }^{47}$

\section{Changes in the set of System-GMM instruments}

13. The first robustness test is based on the choice of System-GMM internal instruments (Table A.4 and A.5). One specification reduces the instrument set to the lowest possible set, while a second specification increases the instrument set to the largest possible. ${ }^{48}$ In both cases, results are qualitatively unchanged, with a few exceptions. The impact of an increase in the legal retirement age is no longer

47. Applying alternative estimates from the robustness analysis performed by Gal and Theising (2015) and Egert (2016) would have the same impact on the macro-effects channelled through labour productivity and labour utilisation for all income groups, i.e. it would imply a parallel shift up or down of the curves for macro-effects presented in the figures in Section 3.

48. See the companion paper for details (Hermansen et al. 2016). 
significant for the poor, but becomes significant for the rich (Table A.5). A reduction in the legal extension of collective agreements now has a significant positive effect on all income groups (Table A.4 and A.5), implying little impact on income inequality. By contrast, a reduction in union density is found to have a stronger disequalising impact than in the baseline estimates, reflecting significant positive effects for the upper-middle class and the rich (Table A.5). 
Table A4. Alternative small set of System-GMM instruments

Estimated total reform-effects on household disposable income by income groups. Baseline estimates reported below

\begin{tabular}{|c|c|c|c|c|c|c|c|c|c|c|}
\hline \multirow{2}{*}{$\begin{array}{l}\text { Structural policy reform } \\
\text { Labour market and welfare policies } \\
\text { Reducing UB replacement rates for all unemployed }\end{array}$} & \multicolumn{2}{|c|}{$\begin{array}{c}\text { The poor } \\
\alpha=-4\end{array}$} & \multicolumn{2}{|c|}{$\begin{array}{c}\text { The lower } \\
\text { middle- } \\
\text { class } \\
\alpha=-1\end{array}$} & \multicolumn{2}{|c|}{$\begin{array}{l}\text { Mean } \\
\text { income } \\
\alpha=1\end{array}$} & \multicolumn{2}{|c|}{$\begin{array}{l}\text { The upper } \\
\text { middle- } \\
\text { class } \\
\alpha=3\end{array}$} & \multicolumn{2}{|c|}{$\begin{array}{l}\text { The rich } \\
\alpha=6\end{array}$} \\
\hline & $\begin{array}{l}-0.29 \\
-0.19\end{array}$ & & $\begin{array}{l}0.14 \\
0.18\end{array}$ & & $\begin{array}{l}0.49 \\
0.59\end{array}$ & * & $\begin{array}{l}0.67 \\
0.82\end{array}$ & * & $\begin{array}{l}0.72 \\
0.81\end{array}$ & * \\
\hline $\begin{array}{l}\text { Reducing UB replacement rates for the } \\
\text { long-term unemployed (including social assistance) }\end{array}$ & $\begin{array}{l}-0.79 \\
-0.74\end{array}$ & * & $\begin{array}{l}-0.41 \\
-0.36\end{array}$ & * & $\begin{array}{l}-0.12 \\
-0.04\end{array}$ & & $\begin{array}{r}-0.04 \\
0.14\end{array}$ & & $\begin{array}{r}-0.05 \\
0.21\end{array}$ & \\
\hline Increasing spending on ALMPs & $\begin{array}{l}1.03 \\
1.12\end{array}$ & * & $\begin{array}{l}0.54 \\
0.58\end{array}$ & * & $\begin{array}{l}0.16 \\
0.14\end{array}$ & & $\begin{array}{l}-0.02 \\
-0.10\end{array}$ & & $\begin{array}{l}-0.09 \\
-0.19\end{array}$ & \\
\hline Increasing the legal retirement age & $\begin{array}{l}0.53 \\
0.44\end{array}$ & * & $\begin{array}{l}0.39 \\
0.38\end{array}$ & * & $\begin{array}{l}0.33 \\
0.31\end{array}$ & * & $\begin{array}{l}0.35 \\
0.35\end{array}$ & * & $\begin{array}{l}0.30 \\
0.30\end{array}$ & \\
\hline $\begin{array}{l}\text { Increasing public spending on families with children } \\
\text { (in-kind family benefits) }\end{array}$ & $\begin{array}{l}25.89 \\
21.93\end{array}$ & * & $\begin{array}{l}11.61 \\
10.80\end{array}$ & * & $\begin{array}{l}0.98 \\
0.69\end{array}$ & & $\begin{array}{l}-4.01 \\
-5.61\end{array}$ & & $\begin{array}{l}-6.13 \\
-8.35\end{array}$ & * \\
\hline Reducing job protection on regular contracts & $\begin{array}{l}-0.19 \\
-0.23\end{array}$ & * & $\begin{array}{l}-0.06 \\
-0.07\end{array}$ & & $\begin{array}{l}0.04 \\
0.04\end{array}$ & & $\begin{array}{l}0.06 \\
0.06\end{array}$ & & $\begin{array}{l}0.07 \\
0.06\end{array}$ & \\
\hline Lower union density & $\begin{array}{l}-0.60 \\
-0.51\end{array}$ & * & $\begin{array}{l}-0.27 \\
-0.24\end{array}$ & * & $\begin{array}{l}-0.03 \\
-0.01\end{array}$ & & $\begin{array}{r}-0.02 \\
0.10\end{array}$ & & $\begin{array}{r}-0.10 \\
0.09\end{array}$ & \\
\hline $\begin{array}{l}\text { Reducing the legal extension of collective } \\
\text { Agreements }\end{array}$ & $\begin{array}{l}0.54 \\
0.41\end{array}$ & * & $\begin{array}{l}0.33 \\
0.31\end{array}$ & * & $\begin{array}{l}0.28 \\
0.36\end{array}$ & * & $\begin{array}{l}0.30 \\
0.53\end{array}$ & * & $\begin{array}{l}0.27 \\
0.64\end{array}$ & * \\
\hline $\begin{array}{l}\text { Encouraging a higher degree of wage bargaining } \\
\text { Coordination }\end{array}$ & $\begin{array}{l}0.25 \\
0.21\end{array}$ & * & $\begin{array}{l}0.14 \\
0.13\end{array}$ & * & $\begin{array}{l}0.05 \\
0.05\end{array}$ & & $\begin{array}{l}-0.02 \\
-0.01\end{array}$ & & $\begin{array}{l}-0.06 \\
-0.05\end{array}$ & \\
\hline Reducing minimum relative to median wage & $\begin{array}{l}-1.08 \\
-0.61\end{array}$ & & $\begin{array}{l}-0.29 \\
-0.11\end{array}$ & & $\begin{array}{l}0.05 \\
0.15\end{array}$ & & $\begin{array}{r}-0.10 \\
0.06\end{array}$ & & $\begin{array}{l}-0.14 \\
-0.01\end{array}$ & \\
\hline $\begin{array}{l}\text { Tax policy } \\
\text { Lowering labour tax wedges (unfinanced) }\end{array}$ & $\begin{array}{l}-0.74 \\
-0.64\end{array}$ & & $\begin{array}{l}-0.24 \\
-0.23\end{array}$ & & $\begin{array}{l}0.37 \\
0.39\end{array}$ & & $\begin{array}{l}0.61 \\
0.76\end{array}$ & * & $\begin{array}{l}0.70 \\
0.91\end{array}$ & * \\
\hline Lowering labour tax wedges (revenue-neutral) & $\begin{array}{l}0.71 \\
0.71\end{array}$ & * & $\begin{array}{l}0.55 \\
0.58\end{array}$ & * & $\begin{array}{l}0.36 \\
0.40\end{array}$ & * & $\begin{array}{l}0.26 \\
0.26\end{array}$ & & $\begin{array}{l}0.14 \\
0.13\end{array}$ & \\
\hline $\begin{array}{l}\text { Education } \\
\text { Increasing public spending on education }\end{array}$ & $\begin{array}{l}8.20 \\
8.17\end{array}$ & * & $\begin{array}{l}5.37 \\
5.03\end{array}$ & * & $\begin{array}{l}3.47 \\
2.91\end{array}$ & * & $\begin{array}{l}3.99 \\
2.00\end{array}$ & & $\begin{array}{l}6.45 \\
2.99\end{array}$ & \\
\hline $\begin{array}{l}\text { Innovation and Technology } \\
\text { Increasing incentives for R\&D spending }\end{array}$ & $\begin{array}{r}-0.13 \\
0.07\end{array}$ & * & $\begin{array}{l}0.04 \\
0.06\end{array}$ & * & $\begin{array}{l}0.08 \\
0.07\end{array}$ & * & $\begin{array}{l}0.12 \\
0.10\end{array}$ & * & $\begin{array}{l}0.14 \\
0.13\end{array}$ & * \\
\hline Increasing incentives for patent application & $\begin{array}{r}-0.01 \\
0.03\end{array}$ & & $\begin{array}{l}0.02 \\
0.02\end{array}$ & & $\begin{array}{l}0.03 \\
0.03\end{array}$ & * & $\begin{array}{l}0.04 \\
0.05\end{array}$ & * & $\begin{array}{l}0.05 \\
0.06\end{array}$ & * \\
\hline $\begin{array}{l}\text { Product market regulation } \\
\text { Reducing barriers to competition }\end{array}$ & $\begin{array}{l}0.27 \\
0.20\end{array}$ & * & $\begin{array}{l}0.29 \\
0.19\end{array}$ & * & $\begin{array}{l}0.30 \\
0.18\end{array}$ & * & $\begin{array}{l}0.30 \\
0.22\end{array}$ & * & $\begin{array}{l}0.35 \\
0.27\end{array}$ & * \\
\hline $\begin{array}{l}\text { Financial sector } \\
\text { Higher share of financial services in the economy }\end{array}$ & $\begin{array}{l}-0.87 \\
-0.63\end{array}$ & * & $\begin{array}{l}-0.53 \\
-0.44\end{array}$ & * & $\begin{array}{l}-0.30 \\
-0.37\end{array}$ & & $\begin{array}{l}-0.34 \\
-0.35\end{array}$ & & $\begin{array}{l}-0.41 \\
-0.27\end{array}$ & \\
\hline
\end{tabular}

Note: Total reform-effects are elasticities or semi-elasticities comprised of macro-level effects through labour productivity and labour utilisation and micro-level effects on household disposable incomes (see Box 2). Baseline estimates reported in Figure 4-20 in the paper are shown below for reference. A star * indicates significance at the $10 \%$ level (see Appendix for computation). The small System-GMM instrument set comprises the 3rd lag for income and the 2nd lag for labour productivity and labour utilisation (not collapsed). See the companion paper for details (Hermansen et al., 2016). 
ECO/WKP(2016)66

Table A5. Alternative large set of System-GMM instruments

Estimated total reform-effects on household disposable income by income groups. Baseline estimates reported below

\begin{tabular}{|c|c|c|c|c|c|c|c|c|c|c|}
\hline \multirow{2}{*}{$\begin{array}{l}\text { Structural policy reform } \\
\text { Labour market and welfare policies } \\
\text { Reducing UB replacement rates for all unemployed }\end{array}$} & \multicolumn{2}{|c|}{$\begin{array}{l}\text { The poor } \\
\alpha=-4\end{array}$} & \multicolumn{2}{|c|}{$\begin{array}{c}\text { The lower } \\
\text { middle- } \\
\text { class } \\
\alpha=-1\end{array}$} & \multicolumn{2}{|c|}{$\begin{array}{l}\text { Mean } \\
\text { income } \\
\alpha=1\end{array}$} & \multicolumn{2}{|c|}{$\begin{array}{c}\text { The upper } \\
\text { middle- } \\
\text { class } \\
\alpha=3\end{array}$} & \multicolumn{2}{|c|}{$\begin{array}{l}\text { The rich } \\
\alpha=6\end{array}$} \\
\hline & $\begin{array}{l}-0.22 \\
-0.19\end{array}$ & & $\begin{array}{l}0.18 \\
0.18\end{array}$ & & $\begin{array}{l}0.63 \\
0.59\end{array}$ & * & $\begin{array}{l}0.94 \\
0.82\end{array}$ & * & $\begin{array}{l}1.07 \\
0.81\end{array}$ & * \\
\hline $\begin{array}{l}\text { Reducing UB replacement rates for the } \\
\text { long-term unemployed (including social assistance) }\end{array}$ & $\begin{array}{l}-0.72 \\
-0.74\end{array}$ & * & $\begin{array}{l}-0.39 \\
-0.36\end{array}$ & * & $\begin{array}{l}-0.06 \\
-0.04\end{array}$ & & $\begin{array}{l}0.15 \\
0.14\end{array}$ & & $\begin{array}{l}0.25 \\
0.21\end{array}$ & \\
\hline Increasing spending on ALMPs & $\begin{array}{l}1.61 \\
1.12\end{array}$ & & $\begin{array}{l}0.54 \\
0.58\end{array}$ & * & $\begin{array}{l}0.14 \\
0.14\end{array}$ & & $\begin{array}{l}-0.14 \\
-0.10\end{array}$ & & $\begin{array}{l}-0.24 \\
-0.19\end{array}$ & \\
\hline Increasing the legal retirement age & $\begin{array}{l}0.99 \\
0.44\end{array}$ & * & $\begin{array}{l}0.28 \\
0.38\end{array}$ & * & $\begin{array}{l}0.27 \\
0.31\end{array}$ & * & $\begin{array}{l}0.33 \\
0.35\end{array}$ & * & $\begin{array}{l}0.38 \\
0.30\end{array}$ & * \\
\hline $\begin{array}{l}\text { Increasing public spending on families with children } \\
\text { (in-kind family benefits) }\end{array}$ & $\begin{array}{l}23.07 \\
21.93\end{array}$ & * & $\begin{array}{r}7.56 \\
10.80\end{array}$ & * & $\begin{array}{r}-1.40 \\
0.69\end{array}$ & & $\begin{array}{l}-8.85 \\
-5.61\end{array}$ & * & $\begin{array}{r}-12.72 \\
-8.35\end{array}$ & * \\
\hline Reducing job protection on regular contracts & $\begin{array}{l}-0.33 \\
-0.23\end{array}$ & * & $\begin{array}{l}-0.14 \\
-0.07\end{array}$ & & $\begin{array}{l}0.03 \\
0.04\end{array}$ & & $\begin{array}{l}0.05 \\
0.06\end{array}$ & & $\begin{array}{l}0.05 \\
0.06\end{array}$ & \\
\hline Lower union density & $\begin{array}{l}-0.48 \\
-0.51\end{array}$ & * & $\begin{array}{l}-0.18 \\
-0.24\end{array}$ & & $\begin{array}{r}0.04 \\
-0.01\end{array}$ & & $\begin{array}{l}0.24 \\
0.10\end{array}$ & * & $\begin{array}{l}0.34 \\
0.09\end{array}$ & * \\
\hline $\begin{array}{l}\text { Reducing the legal extension of collective } \\
\text { agreements }\end{array}$ & $\begin{array}{l}0.33 \\
0.41\end{array}$ & * & $\begin{array}{l}0.22 \\
0.31\end{array}$ & * & $\begin{array}{l}0.27 \\
0.36\end{array}$ & * & $\begin{array}{l}0.37 \\
0.53\end{array}$ & * & $\begin{array}{l}0.39 \\
0.64\end{array}$ & * \\
\hline $\begin{array}{l}\text { Encouraging a higher degree of wage bargaining } \\
\text { coordination }\end{array}$ & $\begin{array}{l}0.26 \\
0.21\end{array}$ & * & $\begin{array}{l}0.13 \\
0.13\end{array}$ & * & $\begin{array}{l}0.03 \\
0.05\end{array}$ & & $\begin{array}{l}-0.02 \\
-0.01\end{array}$ & & $\begin{array}{l}-0.05 \\
-0.05\end{array}$ & \\
\hline Reducing minimum relative to median wage & $\begin{array}{l}-1.12 \\
-0.61\end{array}$ & & $\begin{array}{l}-0.07 \\
-0.11\end{array}$ & & $\begin{array}{l}0.13 \\
0.15\end{array}$ & & $\begin{array}{r}-0.01 \\
0.06\end{array}$ & & $\begin{array}{l}-0.10 \\
-0.01\end{array}$ & \\
\hline $\begin{array}{l}\text { Tax policy } \\
\text { Lowering labour tax wedges (unfinanced) }\end{array}$ & $\begin{array}{l}-1.07 \\
-0.64\end{array}$ & & $\begin{array}{l}-0.17 \\
-0.23\end{array}$ & & $\begin{array}{l}0.43 \\
0.39\end{array}$ & & $\begin{array}{l}0.89 \\
0.76\end{array}$ & * & $\begin{array}{l}1.08 \\
0.91\end{array}$ & * \\
\hline Lowering labour tax wedges (revenue-neutral) & $\begin{array}{l}0.82 \\
0.71\end{array}$ & * & $\begin{array}{l}0.52 \\
0.58\end{array}$ & * & $\begin{array}{l}0.37 \\
0.40\end{array}$ & * & $\begin{array}{l}0.20 \\
0.26\end{array}$ & * & $\begin{array}{l}0.15 \\
0.13\end{array}$ & \\
\hline $\begin{array}{l}\text { Education } \\
\text { Increasing public spending on education }\end{array}$ & $\begin{array}{l}6.69 \\
8.17\end{array}$ & * & $\begin{array}{l}5.52 \\
5.03\end{array}$ & * & $\begin{array}{l}3.59 \\
2.91\end{array}$ & * & $\begin{array}{l}3.03 \\
2.00\end{array}$ & & $\begin{array}{l}3.18 \\
2.99\end{array}$ & \\
\hline $\begin{array}{l}\text { Innovation and Technology } \\
\text { Increasing incentives for R\&D spending }\end{array}$ & $\begin{array}{l}0.40 \\
0.07\end{array}$ & * & $\begin{array}{l}0.17 \\
0.06\end{array}$ & * & $\begin{array}{l}0.10 \\
0.07\end{array}$ & * & $\begin{array}{l}0.16 \\
0.10\end{array}$ & * & $\begin{array}{l}0.20 \\
0.13\end{array}$ & * \\
\hline Increasing incentives for patent application & $\begin{array}{r}-0.01 \\
0.03\end{array}$ & & $\begin{array}{l}0.04 \\
0.02\end{array}$ & * & $\begin{array}{l}0.05 \\
0.03\end{array}$ & * & $\begin{array}{l}0.07 \\
0.05\end{array}$ & * & $\begin{array}{l}0.08 \\
0.06\end{array}$ & * \\
\hline $\begin{array}{l}\text { Product market regulation } \\
\text { Reducing barriers to competition }\end{array}$ & $\begin{array}{l}0.07 \\
0.20\end{array}$ & * & $\begin{array}{l}0.21 \\
0.19\end{array}$ & * & $\begin{array}{l}0.20 \\
0.18\end{array}$ & * & $\begin{array}{l}0.24 \\
0.22\end{array}$ & * & $\begin{array}{l}0.28 \\
0.27\end{array}$ & * \\
\hline $\begin{array}{l}\text { Financial sector } \\
\text { Higher share of financial services in the economy }\end{array}$ & $\begin{array}{l}-0.37 \\
-0.63\end{array}$ & * & $\begin{array}{l}-0.10 \\
-0.44\end{array}$ & * & $\begin{array}{l}-0.06 \\
-0.37\end{array}$ & & $\begin{array}{l}-0.63 \\
-0.35\end{array}$ & & $\begin{array}{l}-2.82 \\
-0.27\end{array}$ & \\
\hline
\end{tabular}

Note: Total reform-effects are elasticities or semi-elasticities comprised of macro-level effects through labour productivity and labour utilisation and micro-level effects on household disposable incomes (see Box 2). Baseline estimates reported in Figure 4-20 in the paper are shown below for reference. A star * indicates significance at the $10 \%$ level (see Appendix for computation). The large System-GMM instrument set comprises all available lags for income, labour productivity and labour utilisation (collapsed). See the companion paper for details (Hermansen et al., 2016). 


\section{Sensitivity of the net exports control}

14. The second test replaces the net exports control variable by the terms-of-trade control variable (export prices to import prices) (Table A.6). Persistent divergences between real mean household income and real GDP have been found to be partly explained by differences in price developments of consumer and output prices, with terms of trade being the main driver (Causa et al., 2014; 2015). Again, conclusions are qualitatively unchanged, with some exceptions though. In some cases, such as reductions in the legal extensions of collective agreements and unfinanced cuts in labour tax wedges, estimated total household income effects are no longer significant, even if their sign and order of magnitude remains close to the baseline estimates. In addition, UB replacement rates cuts targeted to the long-term unemployed and job protection reforms are still found to increase inequality, but now as a result of significant gains to the more affluent households, rather than as a result of significant losses to the least affluent households (as was the case in baseline estimates). Likewise, increases in ALMP are still found to reduce inequality, but now as a result of significant losses to the more affluent households, rather than as a result of significant gains to the least affluent households (as was the case in baseline estimates).

\section{Changes in the sample composition}

15. The third test applies to the sample composition. The sample size, 34 OECD countries, is relatively small and thus leaves little room for proper estimation on subsamples. Therefore, only one test, that is, the exclusion of emerging market economies with the highest levels of inequality (Chile, Mexico and Turkey), is performed (Table A.7). This leaves almost all results qualitatively unchanged. Again, a reduction in the legal extension of collective agreements now has a significant positive effect of the same magnitude for all income groups. Similarly, public spending on education is now estimated to benefit all income groups, albeit still with the largest impact on the least affluent households which implies that it still reduces income inequality. 
ECO/WKP(2016)66

\section{Table A6. Net exports replaced by terms of trade}

Estimated total reform-effects on household disposable income by income groups. Baseline estimates reported below

\begin{tabular}{|c|c|c|c|c|c|c|c|c|c|c|}
\hline Structural policy reform & $\begin{array}{r}\text { The poc } \\
\alpha=-4\end{array}$ & & $\begin{array}{c}\text { The lowe } \\
\text { middle- } \\
\text { class } \\
\alpha=-1\end{array}$ & & $\begin{array}{c}\text { Mean } \\
\text { income } \\
\alpha=1\end{array}$ & & $\begin{array}{c}\text { The upp } \\
\text { middle- } \\
\text { class } \\
\alpha=3\end{array}$ & & \multicolumn{2}{|l|}{$\begin{array}{c}\text { The rich } \\
\alpha=6\end{array}$} \\
\hline Reducing UB replacement rates for all unemployed & $\begin{array}{l}-0.17 \\
-0.19\end{array}$ & & $\begin{array}{l}0.29 \\
0.18\end{array}$ & & $\begin{array}{l}0.85 \\
0.59\end{array}$ & * & $\begin{array}{l}1.15 \\
0.82\end{array}$ & $\stackrel{*}{*}$ & $\begin{array}{l}1.15 \\
0.81\end{array}$ & * \\
\hline $\begin{array}{l}\text { Reducing UB replacement rates for the } \\
\text { long-term unemployed (including social assistance) }\end{array}$ & $\begin{array}{l}-0.41 \\
-0.74\end{array}$ & * & $\begin{array}{l}-0.11 \\
-0.36\end{array}$ & * & $\begin{array}{r}0.28 \\
-0.04\end{array}$ & * & $\begin{array}{l}0.67 \\
0.14\end{array}$ & * & $\begin{array}{l}0.89 \\
0.21\end{array}$ & * \\
\hline Increasing spending on ALMPs & $\begin{array}{l}1.13 \\
1.12\end{array}$ & & $\begin{array}{l}0.56 \\
0.58\end{array}$ & * & $\begin{array}{r}-0.03 \\
0.14\end{array}$ & & $\begin{array}{l}-0.36 \\
-0.10\end{array}$ & * & $\begin{array}{l}-0.47 \\
-0.19\end{array}$ & * \\
\hline Increasing the legal retirement age & $\begin{array}{l}0.30 \\
0.44\end{array}$ & * & $\begin{array}{l}0.33 \\
0.38\end{array}$ & * & $\begin{array}{l}0.34 \\
0.31\end{array}$ & * & $\begin{array}{l}0.47 \\
0.35\end{array}$ & * & $\begin{array}{l}0.46 \\
0.30\end{array}$ & \\
\hline $\begin{array}{l}\text { Increasing public spending on families with children } \\
\text { (in-kind family benefits) }\end{array}$ & $\begin{array}{l}21.26 \\
21.93\end{array}$ & * & $\begin{array}{r}8.85 \\
10.80\end{array}$ & * & $\begin{array}{r}-2.44 \\
0.69\end{array}$ & & $\begin{array}{r}-10.52 \\
-5.61\end{array}$ & * & $\begin{array}{r}-14.40 \\
-8.35\end{array}$ & * \\
\hline Reducing job protection on regular contracts & $\begin{array}{l}-0.12 \\
-0.23\end{array}$ & * & $\begin{array}{r}0.00 \\
-0.07\end{array}$ & & $\begin{array}{l}0.09 \\
0.04\end{array}$ & * & $\begin{array}{l}0.13 \\
0.06\end{array}$ & * & $\begin{array}{l}0.14 \\
0.06\end{array}$ & * \\
\hline Lower union density & $\begin{array}{l}-0.47 \\
-0.51\end{array}$ & * & $\begin{array}{l}-0.17 \\
-0.24\end{array}$ & & $\begin{array}{r}0.11 \\
-0.01\end{array}$ & & $\begin{array}{l}0.30 \\
0.10\end{array}$ & * & $\begin{array}{l}0.37 \\
0.09\end{array}$ & \\
\hline $\begin{array}{l}\text { Reducing the legal extension of collective } \\
\text { agreements }\end{array}$ & $\begin{array}{l}0.13 \\
0.41\end{array}$ & * & $\begin{array}{l}0.14 \\
0.31\end{array}$ & * & $\begin{array}{l}0.19 \\
0.36\end{array}$ & * & $\begin{array}{l}0.28 \\
0.53\end{array}$ & & $\begin{array}{l}0.35 \\
0.64\end{array}$ & \\
\hline $\begin{array}{l}\text { Encouraging a higher degree of wage bargaining } \\
\text { coordination }\end{array}$ & $\begin{array}{l}0.17 \\
0.21\end{array}$ & * & $\begin{array}{l}0.08 \\
0.13\end{array}$ & * & $\begin{array}{r}-0.01 \\
0.05\end{array}$ & & $\begin{array}{l}-0.09 \\
-0.01\end{array}$ & * & $\begin{array}{l}-0.12 \\
-0.05\end{array}$ & * \\
\hline Reducing minimum relative to median wage & $\begin{array}{l}-0.68 \\
-0.61\end{array}$ & & $\begin{array}{l}-0.22 \\
-0.11\end{array}$ & & $\begin{array}{l}0.01 \\
0.15\end{array}$ & & $\begin{array}{r}-0.15 \\
0.06\end{array}$ & & $\begin{array}{l}-0.23 \\
-0.01\end{array}$ & \\
\hline $\begin{array}{l}\text { Tax policy } \\
\text { Lowering labour tax wedges (unfinanced) }\end{array}$ & $\begin{array}{l}-0.80 \\
-0.64\end{array}$ & & $\begin{array}{l}-0.35 \\
-0.23\end{array}$ & & $\begin{array}{l}0.27 \\
0.39\end{array}$ & & $\begin{array}{l}0.48 \\
0.76\end{array}$ & * & $\begin{array}{l}0.51 \\
0.91\end{array}$ & * \\
\hline Lowering labour tax wedges (revenue-neutral) & $\begin{array}{l}0.80 \\
0.71\end{array}$ & * & $\begin{array}{l}0.64 \\
0.58\end{array}$ & * & $\begin{array}{l}0.46 \\
0.40\end{array}$ & * & $\begin{array}{l}0.44 \\
0.26\end{array}$ & * & $\begin{array}{l}0.39 \\
0.13\end{array}$ & \\
\hline $\begin{array}{l}\text { Education } \\
\text { Increasing public spending on education }\end{array}$ & $\begin{array}{l}8.53 \\
8.17\end{array}$ & * & $\begin{array}{l}4.78 \\
5.03\end{array}$ & * & $\begin{array}{l}1.19 \\
2.91\end{array}$ & * & $\begin{array}{r}-3.60 \\
2.00\end{array}$ & & $\begin{array}{r}-5.64 \\
2.99\end{array}$ & \\
\hline $\begin{array}{l}\text { Innovation and Technology } \\
\text { Increasing incentives for } R \& D \text { spending }\end{array}$ & $\begin{array}{l}0.05 \\
0.07\end{array}$ & * & $\begin{array}{l}0.05 \\
0.06\end{array}$ & * & $\begin{array}{l}0.06 \\
0.07\end{array}$ & * & $\begin{array}{l}0.09 \\
0.10\end{array}$ & * & $\begin{array}{l}0.10 \\
0.13\end{array}$ & * \\
\hline Increasing incentives for patent application & $\begin{array}{l}0.02 \\
0.03\end{array}$ & & $\begin{array}{l}0.02 \\
0.02\end{array}$ & & $\begin{array}{l}0.03 \\
0.03\end{array}$ & * & $\begin{array}{l}0.05 \\
0.05\end{array}$ & * & $\begin{array}{l}0.05 \\
0.06\end{array}$ & * \\
\hline $\begin{array}{l}\text { Product market regulation } \\
\text { Reducing barriers to competition }\end{array}$ & $\begin{array}{l}0.16 \\
0.20\end{array}$ & * & $\begin{array}{l}0.16 \\
0.19\end{array}$ & * & $\begin{array}{l}0.16 \\
0.18\end{array}$ & * & $\begin{array}{l}0.19 \\
0.22\end{array}$ & * & $\begin{array}{l}0.21 \\
0.27\end{array}$ & * \\
\hline $\begin{array}{l}\text { Financial sector } \\
\text { Higher share of financial services in the economy }\end{array}$ & $\begin{array}{l}-0.56 \\
-0.63\end{array}$ & * & $\begin{array}{l}-0.33 \\
-0.44\end{array}$ & * & $\begin{array}{l}-0.24 \\
-0.37\end{array}$ & & $\begin{array}{l}-0.19 \\
-0.35 \\
\end{array}$ & & $\begin{array}{l}-0.12 \\
-0.27\end{array}$ & \\
\hline
\end{tabular}

Note: Total reform-effects are elasticities or semi-elasticities comprised of macro-level effects through labour productivity and labour utilisation and micro-level effects on household disposable incomes (see Box 2). Baseline estimates reported in Figure 4-20 in the paper are shown below for reference. A star * indicates significance at the 10\% level (see Appendix for computation). 
ECO/WKP(2016)66

Table A7. Chile, Mexico and Turkey excluded

Estimated total reform-effects on household disposable income by income groups. Baseline estimates reported below

\begin{tabular}{|c|c|c|c|c|c|c|c|c|c|c|}
\hline \multirow{2}{*}{$\begin{array}{l}\text { Structural policy reform } \\
\text { Labour market and welfare policies } \\
\text { Reducing UB replacement rates for all unemployed }\end{array}$} & \multicolumn{2}{|c|}{$\begin{array}{c}\text { The poor } \\
\alpha=-4\end{array}$} & \multicolumn{2}{|c|}{$\begin{array}{l}\text { The lower } \\
\text { middle- } \\
\text { class } \\
\alpha=-1\end{array}$} & \multicolumn{2}{|c|}{$\begin{array}{l}\text { Mean } \\
\text { income } \\
\alpha=1\end{array}$} & \multicolumn{2}{|c|}{$\begin{array}{c}\text { The upper } \\
\text { middle- } \\
\text { class } \\
\alpha=3\end{array}$} & \multicolumn{2}{|c|}{$\begin{array}{c}\text { The rich } \\
\alpha=6\end{array}$} \\
\hline & $\begin{array}{l}-0.22 \\
-0.19\end{array}$ & & $\begin{array}{l}0.17 \\
0.18\end{array}$ & & $\begin{array}{l}0.63 \\
0.59\end{array}$ & * & $\begin{array}{l}0.89 \\
0.82\end{array}$ & * & $\begin{array}{l}0.90 \\
0.81\end{array}$ & * \\
\hline $\begin{array}{l}\text { Reducing UB replacement rates for the } \\
\text { long-term unemployed (including social assistance) }\end{array}$ & $\begin{array}{l}-0.86 \\
-0.74\end{array}$ & * & $\begin{array}{l}-0.39 \\
-0.36\end{array}$ & * & $\begin{array}{l}-0.08 \\
-0.04\end{array}$ & & $\begin{array}{l}0.07 \\
0.14\end{array}$ & & $\begin{array}{l}0.14 \\
0.21\end{array}$ & \\
\hline Increasing spending on ALMPs & $\begin{array}{l}0.65 \\
1.12\end{array}$ & * & $\begin{array}{l}0.33 \\
0.58\end{array}$ & * & $\begin{array}{l}0.09 \\
0.14\end{array}$ & & $\begin{array}{l}-0.07 \\
-0.10\end{array}$ & & $\begin{array}{l}-0.14 \\
-0.19\end{array}$ & \\
\hline Increasing the legal retirement age & $\begin{array}{l}0.36 \\
0.44\end{array}$ & * & $\begin{array}{l}0.37 \\
0.38\end{array}$ & * & $\begin{array}{l}0.43 \\
0.31\end{array}$ & * & $\begin{array}{l}0.42 \\
0.35\end{array}$ & * & $\begin{array}{l}0.39 \\
0.30\end{array}$ & * \\
\hline $\begin{array}{l}\text { Increasing public spending on families with children } \\
\text { (in-kind family benefits) }\end{array}$ & $\begin{array}{l}19.19 \\
21.93\end{array}$ & * & $\begin{array}{r}9.30 \\
10.80\end{array}$ & * & $\begin{array}{l}0.95 \\
0.69\end{array}$ & & $\begin{array}{l}-5.44 \\
-5.61\end{array}$ & & $\begin{array}{l}-8.99 \\
-8.35\end{array}$ & * \\
\hline Reducing job protection on regular contracts & $\begin{array}{l}-0.20 \\
-0.23\end{array}$ & * & $\begin{array}{l}-0.07 \\
-0.07\end{array}$ & & $\begin{array}{l}0.01 \\
0.04\end{array}$ & & $\begin{array}{l}0.04 \\
0.06\end{array}$ & & $\begin{array}{l}0.05 \\
0.06\end{array}$ & \\
\hline Lower union density & $\begin{array}{l}-0.35 \\
-0.51\end{array}$ & * & $\begin{array}{l}-0.14 \\
-0.24\end{array}$ & & $\begin{array}{r}0.04 \\
-0.01\end{array}$ & & $\begin{array}{l}0.16 \\
0.10\end{array}$ & & $\begin{array}{l}0.22 \\
0.09\end{array}$ & * \\
\hline $\begin{array}{l}\text { Reducing the legal extension of collective } \\
\text { agreements }\end{array}$ & $\begin{array}{l}0.34 \\
0.41\end{array}$ & * & $\begin{array}{l}0.29 \\
0.31\end{array}$ & * & $\begin{array}{l}0.32 \\
0.36\end{array}$ & * & $\begin{array}{l}0.37 \\
0.53\end{array}$ & * & $\begin{array}{l}0.39 \\
0.64\end{array}$ & * \\
\hline $\begin{array}{l}\text { Encouraging a higher degree of wage bargaining } \\
\text { coordination }\end{array}$ & $\begin{array}{l}0.21 \\
0.21\end{array}$ & * & $\begin{array}{l}0.13 \\
0.13\end{array}$ & * & $\begin{array}{l}0.05 \\
0.05\end{array}$ & & $\begin{array}{l}-0.01 \\
-0.01\end{array}$ & & $\begin{array}{l}-0.05 \\
-0.05\end{array}$ & \\
\hline Reducing minimum relative to median wage & $\begin{array}{l}-0.42 \\
-0.61\end{array}$ & & $\begin{array}{r}0.02 \\
-0.11\end{array}$ & & $\begin{array}{l}0.25 \\
0.15\end{array}$ & & $\begin{array}{l}0.34 \\
0.06\end{array}$ & & $\begin{array}{r}0.36 \\
-0.01\end{array}$ & \\
\hline $\begin{array}{l}\text { Tax policy } \\
\text { Lowering labour tax wedges (unfinanced) }\end{array}$ & $\begin{array}{l}-0.18 \\
-0.64\end{array}$ & & $\begin{array}{r}0.15 \\
-0.23\end{array}$ & & $\begin{array}{l}0.47 \\
0.39\end{array}$ & * & $\begin{array}{l}0.71 \\
0.76\end{array}$ & * & $\begin{array}{l}0.85 \\
0.91\end{array}$ & * \\
\hline Lowering labour tax wedges (revenue-neutral) & $\begin{array}{l}0.66 \\
0.71\end{array}$ & * & $\begin{array}{l}0.57 \\
0.58\end{array}$ & * & $\begin{array}{l}0.58 \\
0.40\end{array}$ & * & $\begin{array}{l}0.50 \\
0.26\end{array}$ & * & $\begin{array}{l}0.40 \\
0.13\end{array}$ & * \\
\hline $\begin{array}{l}\text { Education } \\
\text { Increasing public spending on education }\end{array}$ & $\begin{array}{l}6.80 \\
8.17\end{array}$ & * & $\begin{array}{l}4.33 \\
5.03\end{array}$ & * & $\begin{array}{l}2.96 \\
2.91\end{array}$ & * & $\begin{array}{l}3.36 \\
2.00\end{array}$ & * & $\begin{array}{l}4.00 \\
2.99\end{array}$ & * \\
\hline $\begin{array}{l}\text { Innovation and Technology } \\
\text { Increasing incentives for } R \& D \text { spending }\end{array}$ & $\begin{array}{l}0.06 \\
0.07\end{array}$ & * & $\begin{array}{l}0.07 \\
0.06\end{array}$ & * & $\begin{array}{l}0.08 \\
0.07\end{array}$ & * & $\begin{array}{l}0.11 \\
0.10\end{array}$ & * & $\begin{array}{l}0.13 \\
0.13\end{array}$ & * \\
\hline Increasing incentives for patent application & $\begin{array}{l}0.02 \\
0.03\end{array}$ & * & $\begin{array}{l}0.03 \\
0.02\end{array}$ & * & $\begin{array}{l}0.03 \\
0.03\end{array}$ & * & $\begin{array}{l}0.05 \\
0.05\end{array}$ & * & $\begin{array}{l}0.06 \\
0.06\end{array}$ & * \\
\hline $\begin{array}{l}\text { Product market regulation } \\
\text { Reducing barriers to competition }\end{array}$ & $\begin{array}{l}0.18 \\
0.20\end{array}$ & * & $\begin{array}{l}0.19 \\
0.19\end{array}$ & * & $\begin{array}{l}0.22 \\
0.18\end{array}$ & * & $\begin{array}{l}0.28 \\
0.22\end{array}$ & * & $\begin{array}{l}0.33 \\
0.27\end{array}$ & * \\
\hline $\begin{array}{l}\text { Financial sector } \\
\text { Higher share of financial services in the economy }\end{array}$ & $\begin{array}{l}-0.63 \\
-0.63\end{array}$ & * & $\begin{array}{l}-0.44 \\
-0.44\end{array}$ & * & $\begin{array}{l}-0.37 \\
-0.37\end{array}$ & & $\begin{array}{l}-0.35 \\
-0.35\end{array}$ & & $\begin{array}{l}-0.27 \\
-0.27\end{array}$ & \\
\hline
\end{tabular}

Note: Total reform-effects are elasticities or semi-elasticities comprised of macro-level effects through labour productivity and labour utilisation and micro-level effects on household disposable incomes (see Box 2). Baseline estimates reported in Figure 4-20 in the paper are shown below for reference. A star * indicates significance at the $10 \%$ level (see Appendix for computation). 


\section{A.3. Simulating growth and inequality effects of policy reforms}

This section documents the simulation of different policy reforms in terms of their impact on growth and inequality. The estimated effects above are taken at face value, and results should therefore be interpreted with caution. Inequality is measured by the Atkinson index, as presented and defined in the paper and in (Hermansen et al., 2016), to allow for differences in aversion to inequality. The Atkinson inequality index is constructed by comparing the arithmetic mean to a general mean of order $\alpha<1$ :

$$
A(x, \alpha)=1-\frac{\mu_{\alpha}(x)}{\mu_{1}(x)}
$$

The simulation exercise applies two different values of $\alpha$ : weak inequality aversion is captured by $\alpha=0.5$, and strong inequality aversion by $\alpha=-4$.

16. The simulation approach can be summarised by the Atkinson index and the following three equations: $:^{49}$

$$
\begin{gathered}
\ln L P=[\ldots]+\varepsilon_{L P, Z} \ln Z=[\ldots]+\sigma_{L P, Z} Z \\
\ln L U=[\ldots]+\varepsilon_{L U, Z} \ln Z=[\ldots]+\sigma_{L U, Z} Z \\
\ln \mu_{\alpha}(x)=[\ldots]+\pi_{L P, \alpha, Z} \ln L P+\pi_{L U, \alpha, Z} \ln L U+D_{\mu_{\alpha}, Z}[\ln ] Z
\end{gathered}
$$

where the policy variable $Z$ is the instrument to be used to "shock" the system and all coefficients have been defined in previous steps. Note that some policies are measured in levels and some are logtransformed. Therefore, it is necessary to distinguish between effects expressed in terms of elasticities and semi-elasticities.

17. To be able to simulate effects on the basis of estimated effects only, and avoid the need to invoke income levels and other variables included in the estimation model, it is useful to consider the total differential of the system of equations:

$$
\begin{gathered}
\frac{1}{L P} d L P=\varepsilon_{L P, Z} \frac{1}{Z} d Z=\sigma_{L P, Z} d Z \\
\frac{1}{L U} d L U=\varepsilon_{L U, Z} \frac{1}{Z} d Z=\sigma_{L U, Z} d Z \\
\frac{1}{\mu_{\alpha}(x)} d \mu_{\alpha}(x)=\pi_{L P, \alpha, Z} \frac{1}{L P} d L P+\pi_{L U, \alpha, Z} \frac{1}{L U} d L U+D_{\mu_{\alpha}, Z}\left[\frac{1}{Z}\right] d Z \\
d A(x, \alpha)=-\frac{1}{\mu_{1}(x)} d \mu_{\alpha}(x)+\frac{\mu_{\alpha}(x)}{\left[\mu_{1}(x)\right]^{2}} d \mu_{1}(x)=[A(x, \alpha)-1]\left[\frac{d \mu_{\alpha}(x)}{\mu_{\alpha}(x)}-\frac{d \mu_{1}(x)}{\mu_{1}(x)}\right]
\end{gathered}
$$

18. For a "small" change in the policy variable of magnitude $\Delta$ it approximately holds that

$$
\frac{\Delta L P}{L P}=\varepsilon_{L P, Z} \frac{\Delta Z}{Z}=\sigma_{L P, Z} \Delta Z
$$

49. Additional terms irrelevant for the simulation are left out and represented by [...] to ease presentation. 


$$
\begin{gathered}
\frac{\Delta L U}{L U}=\varepsilon_{L U, Z} \frac{\Delta Z}{Z}=\sigma_{L U, Z} \Delta Z \\
\frac{\Delta \mu_{\alpha}(x)}{\mu_{\alpha}(x)}=E_{\mu_{\alpha}, Z} \frac{\Delta Z}{Z}=S_{\mu_{\alpha}, Z} \Delta Z \\
\Delta A(x, \alpha)=[A(x, \alpha)-1]\left[\frac{\Delta \mu_{\alpha}(x)}{\mu_{\alpha}(x)}-\frac{\Delta \mu_{1}(x)}{\mu_{1}(x)}\right]
\end{gathered}
$$

19. Combining equations yield the following reduced form of the simulated effect of a policy reform on income inequality:

$$
\Delta A(x, \alpha)=[\mathrm{A}(x, \alpha)-1]\left[E_{\mu_{\alpha}, Z}-E_{\mu_{1}, Z}\right] \frac{\Delta Z}{Z}=[A(x, \alpha)-1]\left[S_{\mu_{\alpha}, Z}-S_{\mu_{1}, Z}\right] \Delta Z
$$

20. By construction, the Atkinson index is bounded between 0 and 1 . Hence, the first bracket is negative, implying that a given policy reform will reduce income inequality if $E_{\mu_{\alpha}, Z}>E_{\mu_{1}, Z}$, i.e. if postreform household income grows more for bottom-sensitive general means $(\alpha<1)$ than for average income $(\alpha=1)$. It can also be observed that the level of the Atkinson index enters the equation. This implies that for a higher (lower) level of initial inequality, the change in income inequality associated with a given policy reform scenario will be smaller (larger) in absolute terms. Thus, a policy that is estimated to increase inequality will have a quantitatively larger effect on relatively more equal countries than on relatively more unequal countries. As a result, reform simulations are presented by setting the Atkinson index at its OECD average level for the latest available year. ${ }^{50}$

21. A policy change can be calibrated in several ways. For instance, by simply standardising the policy change, i.e. considering one standard deviation change in $Z$ across OECD countries in latest available year (see Table A.9 below). Alternatively to achieve a given growth target in:

- $\quad$ Labour productivity, e.g. fixing $\frac{\Delta L P}{L P}=1 \%$

- $\quad$ Labour utilisation, e.g. fixing $\frac{\Delta L U}{L U}=1 \%$

- Household income for some income group as governed by $\alpha$, e.g. mean income, that is, $\frac{\Delta \mu_{\alpha}(x)}{\mu_{\alpha}(x)}=$ $1 \%$ for $\alpha=1$

22. When a simulation target has been set, the implied changes in other variables can be computed from the equations above.

Example: A reduction in the UB average gross replacement rate to deliver a $1 \%$ increase in labour utilisation. The required policy change is given by:

$$
\frac{\Delta L U}{L U}=\sigma_{L U, Z} \Delta Z \Rightarrow \Delta Z=\frac{1}{\sigma_{L U, Z}} \frac{\Delta L U}{L U}=-\frac{1}{0.25} \cdot 1=-3.94
$$

50. In this case applying the average Atkinson index is equivalent to computing the effect for each country and then averaging. This follows from the linearization of the model implied by considering total differentials (see above). 
The implied change in mean household income is given by

$$
\frac{\Delta \mu_{1}(x)}{\mu_{1}(x)}=S_{\mu_{\alpha}, Z} \Delta Z=(-0.59) \cdot(-3.94)=2.34
$$

The implied change in the Atkinson index (for weak and strong inequality aversion, respectively) is given by

$$
\begin{gathered}
\Delta A(x, 0.5)=[A(x, 0.5)-1]\left[S_{\mu_{0.5}, Z}-S_{\mu_{1}, Z}\right] \Delta Z=[0.0796-1][-0.49-(-0.59)](-3.94)=0.39 \\
\Delta A(x,-4)=[A(x,-4)-1]\left[S_{\mu_{-4}, Z}-S_{\mu_{1}, Z}\right] \Delta Z=[0.52-1][0-(-0.59)](-3.94)=1.13
\end{gathered}
$$

where $A(x, 0.5)=0.0796$ and $A(x,-4)=0.52$ correspond to the average values of the Atkinson indices across OECD countries in the latest available year (see Figure 1). The effects are reported on scale 0-100, following the scaling of semi-elasticities by 100. In sum, to achieve a $1 \%$ increase in labour utilisation, the simulation implies that the UB replacement rate should be reduced by 3.94 percentage points. Such reform is estimated to increase mean household income by $2.34 \%$. Income inequality under weak inequality aversion, as measured by the Atkinson index for $\alpha=0.5$ is estimated to increase by 0.39 point (from an initial cross-country average level of 7.96), whereas income inequality under strong inequality aversion, as measured by the Atkinson inequality index for $\alpha=-4$ is estimated to increase by 1.13 points (from an initial cross-country average level of 51.6).

\section{A.4. Data availability and descriptive statistics}

Tables A.8 and A.9 provide descriptive statistics such as the average, standard deviation and

\begin{tabular}{|c|c|c|c|c|c|}
\hline Policy & Countries & Average & Std. dev & Min & Max \\
\hline Unemployment benefit gross replacement rate & 29 & 25.64 & 11.78 & 6.23 & 42.81 \\
\hline $\begin{array}{l}\text { Unemployment benefit net replacement rate for long-term } \\
\text { unemployed }\end{array}$ & 25 & 30.33 & 16.96 & 0.00 & 58.00 \\
\hline ALMP spending (in \% of GDP per capita, trend from HP-filter) & 32 & 15.96 & 12.64 & 0.43 & 52.14 \\
\hline Legal retirement age & 34 & 63.07 & 3.78 & 45 & 67 \\
\hline Government spending on family benefits in-kind (in \% of GDP) & 34 & 0.94 & 0.59 & 0.00 & 2.42 \\
\hline Employment protection legislation (EPL, regular contracts) & 34 & 2.08 & 0.64 & 0.26 & 3.56 \\
\hline Union density & 34 & 27.08 & 20.10 & 4.54 & 82.60 \\
\hline $\begin{array}{l}\text { Excess coverage of wage bargaining (bargaining coverage } \\
\text { less union density) }\end{array}$ & 33 & 26.63 & 24.97 & -7.92 & 84.41 \\
\hline Coordination of wage bargaining (index $1-5$ ) & 28 & 2.82 & 1.33 & 1.00 & 5.00 \\
\hline Minimum wage (in \% of median wage) & 25 & 49.15 & 9.91 & 35.90 & 71.10 \\
\hline Labour tax wedge (couple with single earner and 2 children) & 34 & 26.26 & 11.15 & 0.55 & 43.90 \\
\hline Government expenditure on education (in \% of GDP) & 34 & 5.28 & 1.19 & 2.86 & 8.55 \\
\hline General expenditure on R\&D (in \% of GDP) & 34 & 2.01 & 1.01 & 0.36 & 4.25 \\
\hline Patent applications filed under the PCT (per capita) & 34 & $1.18 \mathrm{E}-4$ & $1.05 \mathrm{E}-4$ & $1.96 \mathrm{E}-6$ & $3.42 \mathrm{E}-4$ \\
\hline $\begin{array}{l}\text { Energy, transport and communication regulation (ETCR, } \\
\text { aggregate; index 0-6) }\end{array}$ & 34 & 2.12 & 0.53 & 0.79 & 3.20 \\
\hline $\begin{array}{l}\text { Value added of financial and insurance activities (in \% of } \\
\text { GDP) }\end{array}$ & 15 & 4.72 & 1.46 & 2.30 & 8.30 \\
\hline
\end{tabular}
minimum and maximum values as well as the availability of data for all countries.

Table A8. Descriptive statistics of policy indicators

Source: Structural Policy Indicators Database; OECD National Accounts. 
Table A9. Country and time coverage in the empirical analysis

\begin{tabular}{|c|c|c|c|c|c|c|c|c|c|c|c|c|c|c|c|c|}
\hline & 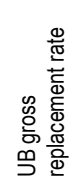 & 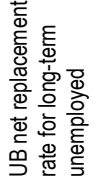 & 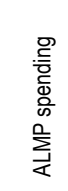 & 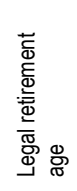 & 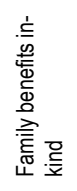 & $\overrightarrow{\mathrm{H}}$ & 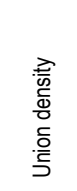 & 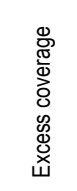 & 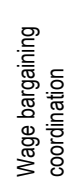 & 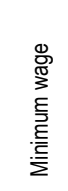 & 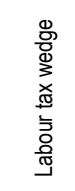 & 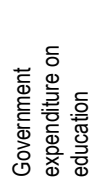 & 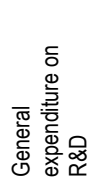 & 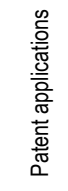 & $\begin{array}{l}\frac{\Upsilon}{\circlearrowright} \\
\frac{5}{w}\end{array}$ & 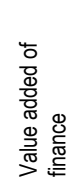 \\
\hline AUS & $\begin{array}{l}1996- \\
2010\end{array}$ & $\begin{array}{l}2002- \\
2012\end{array}$ & $\begin{array}{l}1996- \\
2010\end{array}$ & $\begin{array}{l}1996- \\
2012\end{array}$ & $\begin{array}{l}1996- \\
2012\end{array}$ & $\begin{array}{l}1996- \\
2012\end{array}$ & $\begin{array}{l}1996- \\
2012\end{array}$ & $\begin{array}{l}1996- \\
1996\end{array}$ & $\begin{array}{l}1996- \\
2010\end{array}$ & $\begin{array}{l}1996- \\
2012\end{array}$ & $\begin{array}{l}1996- \\
2012\end{array}$ & $\begin{array}{l}1996- \\
2012\end{array}$ & $\begin{array}{l}1996- \\
2010\end{array}$ & $\begin{array}{l}1996- \\
2012\end{array}$ & $\begin{array}{l}1996- \\
2012\end{array}$ & \\
\hline AUT & $\begin{array}{l}2004- \\
2010\end{array}$ & $\begin{array}{l}2004- \\
2012\end{array}$ & $\begin{array}{l}2004- \\
2012\end{array}$ & $\begin{array}{l}2004- \\
2012\end{array}$ & $\begin{array}{l}2004- \\
2010\end{array}$ & $\begin{array}{l}2004- \\
2012\end{array}$ & $\begin{array}{l}2004- \\
2012\end{array}$ & $\begin{array}{l}2004- \\
2010\end{array}$ & $\begin{array}{l}2004- \\
2010\end{array}$ & & $\begin{array}{l}2004- \\
2012\end{array}$ & $\begin{array}{l}2004- \\
2010\end{array}$ & $\begin{array}{l}2004- \\
2012\end{array}$ & $\begin{array}{l}2004- \\
2012\end{array}$ & $\begin{array}{l}2004- \\
2012\end{array}$ & $\begin{array}{l}2004- \\
2010\end{array}$ \\
\hline BEL & $\begin{array}{l}2004- \\
2010\end{array}$ & $\begin{array}{l}2004- \\
2012\end{array}$ & $\begin{array}{l}2004- \\
2012\end{array}$ & $\begin{array}{l}2004- \\
2012\end{array}$ & $\begin{array}{l}2004- \\
2010\end{array}$ & $\begin{array}{l}2004- \\
2012\end{array}$ & $\begin{array}{l}2004- \\
2012\end{array}$ & $\begin{array}{l}2004- \\
2010\end{array}$ & $\begin{array}{l}2004- \\
2010\end{array}$ & $\begin{array}{l}2004- \\
2012\end{array}$ & $\begin{array}{l}2004- \\
2012\end{array}$ & $\begin{array}{l}2004- \\
2010\end{array}$ & $\begin{array}{l}2004- \\
2012\end{array}$ & $\begin{array}{l}2004- \\
2012\end{array}$ & $\begin{array}{l}2004- \\
2012\end{array}$ & $\begin{array}{l}2004- \\
2010\end{array}$ \\
\hline CAN & $\begin{array}{l}1985- \\
2011\end{array}$ & $\begin{array}{l}2001- \\
2011\end{array}$ & $\begin{array}{l}1985- \\
2011\end{array}$ & $\begin{array}{l}1985- \\
2011\end{array}$ & $\begin{array}{l}1985- \\
2011\end{array}$ & $\begin{array}{l}1985- \\
2011\end{array}$ & $\begin{array}{l}1985- \\
2011\end{array}$ & $\begin{array}{l}1985- \\
2011\end{array}$ & $\begin{array}{l}1985- \\
2011\end{array}$ & $\begin{array}{l}1985- \\
2011\end{array}$ & $\begin{array}{l}1985- \\
2011\end{array}$ & $\begin{array}{l}1985- \\
2011\end{array}$ & $\begin{array}{l}1985- \\
2011\end{array}$ & $\begin{array}{l}1985- \\
2011\end{array}$ & $\begin{array}{l}1985- \\
2011\end{array}$ & \\
\hline $\mathrm{CHE}$ & $\begin{array}{l}2009- \\
2011\end{array}$ & $\begin{array}{l}2009- \\
2011\end{array}$ & $\begin{array}{l}2009- \\
2011\end{array}$ & $\begin{array}{l}2009- \\
2011\end{array}$ & $\begin{array}{l}2009- \\
2011\end{array}$ & $\begin{array}{l}2009- \\
2011\end{array}$ & $\begin{array}{l}2009- \\
2011\end{array}$ & 2009 & & & $\begin{array}{l}2009- \\
2011\end{array}$ & $\begin{array}{l}2009- \\
2011\end{array}$ & $\begin{array}{l}2009- \\
2011\end{array}$ & $\begin{array}{l}2009- \\
2011\end{array}$ & $\begin{array}{l}2009- \\
2011\end{array}$ & \\
\hline $\mathrm{CHL}$ & & $\begin{array}{l}2011- \\
2011\end{array}$ & $\begin{array}{l}2009- \\
2011\end{array}$ & $\begin{array}{l}2007- \\
2011\end{array}$ & $\begin{array}{l}2007- \\
2011\end{array}$ & $\begin{array}{l}2009- \\
2011\end{array}$ & $\begin{array}{l}2007- \\
2011\end{array}$ & 2007 & & $\begin{array}{l}2009- \\
2011\end{array}$ & $\begin{array}{l}2007- \\
2011\end{array}$ & $\begin{array}{l}2007- \\
2011\end{array}$ & $\begin{array}{l}2007- \\
2011\end{array}$ & $\begin{array}{l}2007- \\
2011\end{array}$ & $\begin{array}{l}2007- \\
2011\end{array}$ & \\
\hline CZE & $\begin{array}{l}2004- \\
2010\end{array}$ & $\begin{array}{l}2004- \\
2012\end{array}$ & $\begin{array}{l}2004- \\
2012\end{array}$ & $\begin{array}{l}2004- \\
2012\end{array}$ & $\begin{array}{l}2004- \\
2010\end{array}$ & $\begin{array}{l}2004- \\
2012\end{array}$ & $\begin{array}{l}2004- \\
2012\end{array}$ & $\begin{array}{l}2004- \\
2008\end{array}$ & $\begin{array}{l}2004- \\
2010\end{array}$ & $\begin{array}{l}2004- \\
2012\end{array}$ & $\begin{array}{l}2004- \\
2012\end{array}$ & $\begin{array}{l}2004- \\
2010\end{array}$ & $\begin{array}{l}2004- \\
2012\end{array}$ & $\begin{array}{l}2004- \\
2012\end{array}$ & $\begin{array}{l}2004- \\
2012\end{array}$ & $\begin{array}{l}2004- \\
2010\end{array}$ \\
\hline DEU & $\begin{array}{l}1986- \\
2010\end{array}$ & $\begin{array}{l}2002- \\
2010\end{array}$ & $\begin{array}{l}1986- \\
2010\end{array}$ & $\begin{array}{l}1986- \\
2010\end{array}$ & $\begin{array}{l}1986- \\
2010\end{array}$ & $\begin{array}{l}1986- \\
2010\end{array}$ & $\begin{array}{l}1986- \\
2010\end{array}$ & $\begin{array}{l}1986- \\
2010\end{array}$ & $\begin{array}{l}1986- \\
2010\end{array}$ & & $\begin{array}{l}1986- \\
2010\end{array}$ & $\begin{array}{l}1994- \\
2010\end{array}$ & $\begin{array}{l}1986- \\
2010\end{array}$ & $\begin{array}{l}1986- \\
2010\end{array}$ & $\begin{array}{l}1986- \\
2010\end{array}$ & $\begin{array}{l}1992- \\
2010\end{array}$ \\
\hline DNK & $\begin{array}{l}1985- \\
2011\end{array}$ & $\begin{array}{l}2001- \\
2011\end{array}$ & $\begin{array}{l}1987- \\
2011\end{array}$ & $\begin{array}{l}1985- \\
2011\end{array}$ & $\begin{array}{l}1985- \\
2011\end{array}$ & $\begin{array}{l}1985- \\
2011\end{array}$ & $\begin{array}{l}1985- \\
2011\end{array}$ & $\begin{array}{l}1985- \\
2007\end{array}$ & $\begin{array}{l}1985- \\
2011\end{array}$ & & $\begin{array}{l}1985- \\
2011\end{array}$ & $\begin{array}{l}1985- \\
2011\end{array}$ & $\begin{array}{l}1985- \\
2011\end{array}$ & $\begin{array}{l}1985- \\
2011\end{array}$ & $\begin{array}{l}1985- \\
2011\end{array}$ & $\begin{array}{l}1985- \\
2011\end{array}$ \\
\hline ESP & $\begin{array}{l}2004- \\
2010\end{array}$ & $\begin{array}{l}2004- \\
2012\end{array}$ & $\begin{array}{l}2004- \\
2010\end{array}$ & $\begin{array}{l}2004- \\
2012\end{array}$ & $\begin{array}{l}2004- \\
2010\end{array}$ & $\begin{array}{l}2004- \\
2012\end{array}$ & $\begin{array}{l}2004- \\
2012\end{array}$ & $\begin{array}{l}2004- \\
2010\end{array}$ & $\begin{array}{l}2004- \\
2010\end{array}$ & $\begin{array}{l}2004- \\
2012\end{array}$ & $\begin{array}{l}2004- \\
2012\end{array}$ & $\begin{array}{l}2004- \\
2012\end{array}$ & $\begin{array}{l}2004- \\
2012\end{array}$ & $\begin{array}{l}2004- \\
2012\end{array}$ & $\begin{array}{l}2004- \\
2012\end{array}$ & \\
\hline EST & & $\begin{array}{l}2006- \\
2012\end{array}$ & $\begin{array}{l}2004- \\
2012\end{array}$ & $\begin{array}{l}2004- \\
2012\end{array}$ & $\begin{array}{l}2004- \\
2010\end{array}$ & $\begin{array}{l}2008- \\
2012\end{array}$ & $\begin{array}{l}2004- \\
2012\end{array}$ & $\begin{array}{l}2004- \\
2008\end{array}$ & $\begin{array}{l}2004- \\
2010\end{array}$ & $\begin{array}{l}2004- \\
2012\end{array}$ & $\begin{array}{l}2004- \\
2012\end{array}$ & $\begin{array}{l}2004- \\
2010\end{array}$ & $\begin{array}{l}2004- \\
2012\end{array}$ & $\begin{array}{l}2004- \\
2012\end{array}$ & $\begin{array}{l}2004- \\
2012\end{array}$ & \\
\hline FIN & $\begin{array}{l}1986- \\
2010\end{array}$ & $\begin{array}{l}2002- \\
2012\end{array}$ & $\begin{array}{l}1986- \\
2012\end{array}$ & $\begin{array}{l}1986- \\
2012\end{array}$ & $\begin{array}{l}1986- \\
2010\end{array}$ & $\begin{array}{l}1986- \\
2012\end{array}$ & $\begin{array}{l}1986- \\
2012\end{array}$ & $\begin{array}{l}1986- \\
2008\end{array}$ & $\begin{array}{l}1986- \\
2010\end{array}$ & & $\begin{array}{l}1986- \\
2012\end{array}$ & $\begin{array}{l}1986- \\
2012\end{array}$ & $\begin{array}{l}1986- \\
2012\end{array}$ & $\begin{array}{l}1986- \\
2012\end{array}$ & $\begin{array}{l}1986- \\
2012\end{array}$ & $\begin{array}{l}1986- \\
2010\end{array}$ \\
\hline FRA & $\begin{array}{l}1996- \\
2010\end{array}$ & $\begin{array}{l}2002- \\
2010\end{array}$ & $\begin{array}{l}1996- \\
2010\end{array}$ & $\begin{array}{l}1996- \\
2010\end{array}$ & $\begin{array}{l}1996- \\
2010\end{array}$ & $\begin{array}{l}1996- \\
2010\end{array}$ & $\begin{array}{l}1996- \\
2010\end{array}$ & $\begin{array}{l}1996- \\
2008\end{array}$ & $\begin{array}{l}1996- \\
2010\end{array}$ & $\begin{array}{l}1996- \\
2010\end{array}$ & $\begin{array}{l}1996- \\
2010\end{array}$ & $\begin{array}{l}1996- \\
2010\end{array}$ & $\begin{array}{l}1996- \\
2010\end{array}$ & $\begin{array}{l}1996- \\
2010\end{array}$ & $\begin{array}{l}1996- \\
2010\end{array}$ & $\begin{array}{l}1996- \\
2010\end{array}$ \\
\hline GBR & $\begin{array}{l}1999- \\
2009\end{array}$ & $\begin{array}{l}2001- \\
2009\end{array}$ & $\begin{array}{l}1999- \\
2009\end{array}$ & $\begin{array}{l}1999- \\
2009\end{array}$ & $\begin{array}{l}1999- \\
2009\end{array}$ & $\begin{array}{l}1999- \\
2009\end{array}$ & $\begin{array}{l}1999- \\
2009\end{array}$ & $\begin{array}{l}1999- \\
2009\end{array}$ & $\begin{array}{l}1999- \\
2009\end{array}$ & $\begin{array}{l}1999- \\
2009\end{array}$ & $\begin{array}{l}1999- \\
2009\end{array}$ & $\begin{array}{l}1999- \\
2009\end{array}$ & $\begin{array}{l}1999- \\
2009\end{array}$ & $\begin{array}{l}1999- \\
2009\end{array}$ & $\begin{array}{l}1999- \\
2009\end{array}$ & \\
\hline GRC & $\begin{array}{l}1995- \\
2009\end{array}$ & $\begin{array}{l}2001- \\
2009\end{array}$ & $\begin{array}{l}1995- \\
2009\end{array}$ & $\begin{array}{l}1995- \\
2009\end{array}$ & $\begin{array}{l}1995- \\
2009\end{array}$ & $\begin{array}{l}1995- \\
2009\end{array}$ & $\begin{array}{l}1995- \\
2009\end{array}$ & $\begin{array}{l}1995- \\
2007\end{array}$ & $\begin{array}{l}1995- \\
2009\end{array}$ & $\begin{array}{l}1995- \\
2009\end{array}$ & $\begin{array}{l}1995- \\
2009\end{array}$ & $\begin{array}{l}1995- \\
2005\end{array}$ & $\begin{array}{l}1995- \\
2009\end{array}$ & $\begin{array}{l}1995- \\
2009\end{array}$ & $\begin{array}{l}1995- \\
2009\end{array}$ & \\
\hline HUN & $\begin{array}{l}2001- \\
2011\end{array}$ & $\begin{array}{l}2001- \\
2011\end{array}$ & $\begin{array}{l}1995- \\
2011\end{array}$ & $\begin{array}{l}1995- \\
2011\end{array}$ & $\begin{array}{l}1999- \\
2011\end{array}$ & $\begin{array}{l}1995- \\
2011\end{array}$ & $\begin{array}{l}1995- \\
2011\end{array}$ & $\begin{array}{l}1999- \\
2007\end{array}$ & $\begin{array}{l}1995- \\
2011\end{array}$ & $\begin{array}{l}1995- \\
2011\end{array}$ & $\begin{array}{l}1995- \\
2011\end{array}$ & $\begin{array}{l}1995- \\
2011\end{array}$ & $\begin{array}{l}1995- \\
2011\end{array}$ & $\begin{array}{l}1995- \\
2011\end{array}$ & $\begin{array}{l}1995- \\
2011\end{array}$ & $\begin{array}{l}1995- \\
2009\end{array}$ \\
\hline IRL & $\begin{array}{l}2004- \\
2010\end{array}$ & $\begin{array}{l}2004- \\
2012\end{array}$ & $\begin{array}{l}2004- \\
2010\end{array}$ & $\begin{array}{l}2004- \\
2012\end{array}$ & $\begin{array}{l}2004- \\
2010\end{array}$ & $\begin{array}{l}2004- \\
2012\end{array}$ & $\begin{array}{l}2004- \\
2012\end{array}$ & $\begin{array}{l}2004- \\
2010\end{array}$ & $\begin{array}{l}2004- \\
2010\end{array}$ & $\begin{array}{l}2004- \\
2012\end{array}$ & $\begin{array}{l}2004- \\
2012\end{array}$ & $\begin{array}{l}2004- \\
2010\end{array}$ & $\begin{array}{l}2004- \\
2012\end{array}$ & $\begin{array}{l}2004- \\
2012\end{array}$ & $\begin{array}{l}2004- \\
2012\end{array}$ & \\
\hline ISL & $\begin{array}{l}2004- \\
2010\end{array}$ & $\begin{array}{l}2004- \\
2012\end{array}$ & & $\begin{array}{l}2004- \\
2012\end{array}$ & $\begin{array}{l}2004- \\
2010\end{array}$ & $\begin{array}{l}2008- \\
2012\end{array}$ & $\begin{array}{l}2004- \\
2012\end{array}$ & $\begin{array}{l}2004- \\
2008\end{array}$ & & & $\begin{array}{l}2004- \\
2012\end{array}$ & $\begin{array}{l}2004- \\
2010\end{array}$ & $\begin{array}{l}2004- \\
2012\end{array}$ & $\begin{array}{l}2004- \\
2012\end{array}$ & $\begin{array}{l}2004- \\
2012\end{array}$ & \\
\hline ISR & & $\begin{array}{l}2009- \\
2011\end{array}$ & $\begin{array}{l}2005- \\
2011\end{array}$ & $\begin{array}{l}1995- \\
2011\end{array}$ & $\begin{array}{l}1995- \\
2011\end{array}$ & $\begin{array}{l}2009- \\
2011\end{array}$ & $\begin{array}{l}1995- \\
2007\end{array}$ & $\begin{array}{l}1995- \\
1999\end{array}$ & $\begin{array}{l}1995- \\
2009\end{array}$ & $\begin{array}{l}2001- \\
2011\end{array}$ & $\begin{array}{l}2001- \\
2011\end{array}$ & $\begin{array}{l}1995- \\
2011\end{array}$ & $\begin{array}{l}1995- \\
2011\end{array}$ & $\begin{array}{l}1995- \\
2011\end{array}$ & $\begin{array}{l}1995- \\
2011\end{array}$ & \\
\hline ITA & $\begin{array}{l}1991- \\
2011\end{array}$ & $\begin{array}{l}2001- \\
2011\end{array}$ & $\begin{array}{l}2005- \\
2011\end{array}$ & $\begin{array}{l}1991- \\
2011\end{array}$ & $\begin{array}{l}1991- \\
2011\end{array}$ & $\begin{array}{l}1991- \\
2011\end{array}$ & $\begin{array}{l}1991- \\
2011\end{array}$ & $\begin{array}{l}1991- \\
2009\end{array}$ & $\begin{array}{l}1991- \\
2011\end{array}$ & & $\begin{array}{l}1991- \\
2011\end{array}$ & $\begin{array}{l}1991- \\
2011\end{array}$ & $\begin{array}{l}1991- \\
2011\end{array}$ & $\begin{array}{l}1991- \\
2011\end{array}$ & $\begin{array}{l}1991- \\
2011\end{array}$ & $\begin{array}{l}1991- \\
2011\end{array}$ \\
\hline JPN & $\begin{array}{l}1995- \\
2009\end{array}$ & $\begin{array}{l}2001- \\
2009\end{array}$ & $\begin{array}{l}1995- \\
2009\end{array}$ & $\begin{array}{l}1995- \\
2009\end{array}$ & $\begin{array}{l}1995- \\
2009\end{array}$ & $\begin{array}{l}1995- \\
2009\end{array}$ & $\begin{array}{l}1995- \\
2009\end{array}$ & $\begin{array}{l}1995- \\
2007\end{array}$ & & $\begin{array}{l}1995- \\
2009\end{array}$ & $\begin{array}{l}1995- \\
2009\end{array}$ & $\begin{array}{l}1995- \\
2009\end{array}$ & $\begin{array}{l}1995- \\
2009\end{array}$ & $\begin{array}{l}1995- \\
2009\end{array}$ & $\begin{array}{l}1995- \\
2009\end{array}$ & \\
\hline KOR & $\begin{array}{l}2006- \\
2010\end{array}$ & $\begin{array}{l}2006- \\
2012\end{array}$ & $\begin{array}{l}2006- \\
2012\end{array}$ & $\begin{array}{l}2006- \\
2012\end{array}$ & $\begin{array}{l}2006- \\
2012\end{array}$ & $\begin{array}{l}2006- \\
2012\end{array}$ & $\begin{array}{l}2006- \\
2010\end{array}$ & $\begin{array}{l}2006- \\
2008\end{array}$ & $\begin{array}{l}2006- \\
2010\end{array}$ & $\begin{array}{l}2006- \\
2012\end{array}$ & $\begin{array}{l}2006- \\
2012\end{array}$ & $\begin{array}{l}2006- \\
2012\end{array}$ & $\begin{array}{l}2006- \\
2012\end{array}$ & $\begin{array}{l}2006- \\
2012\end{array}$ & $\begin{array}{l}2006- \\
2012\end{array}$ & $\begin{array}{l}2006- \\
2010\end{array}$ \\
\hline LUX & $\begin{array}{l}2004- \\
2010\end{array}$ & $\begin{array}{l}2004- \\
2012\end{array}$ & $\begin{array}{l}2004- \\
2010\end{array}$ & $\begin{array}{l}2004- \\
2012\end{array}$ & $\begin{array}{l}2004- \\
2010\end{array}$ & $\begin{array}{l}2008- \\
2012\end{array}$ & $\begin{array}{l}2004- \\
2012\end{array}$ & $\begin{array}{l}2004- \\
2008\end{array}$ & $\begin{array}{l}2004- \\
2010\end{array}$ & $\begin{array}{l}2004- \\
2012\end{array}$ & $\begin{array}{l}2004- \\
2012\end{array}$ & & $\begin{array}{l}2004- \\
2012\end{array}$ & $\begin{array}{l}2004- \\
2012\end{array}$ & $\begin{array}{l}2004- \\
2012\end{array}$ & \\
\hline MEX & & $\begin{array}{l}2002- \\
2012\end{array}$ & $\begin{array}{l}2000- \\
2012\end{array}$ & $\begin{array}{l}2000- \\
2012\end{array}$ & $\begin{array}{l}2000- \\
2010\end{array}$ & $\begin{array}{l}2000- \\
2012\end{array}$ & $\begin{array}{l}2000- \\
2012\end{array}$ & & & $\begin{array}{l}2006- \\
2012\end{array}$ & $\begin{array}{l}2000- \\
2012\end{array}$ & $\begin{array}{l}2000- \\
2010\end{array}$ & $\begin{array}{l}2000- \\
2012\end{array}$ & $\begin{array}{l}2000- \\
2012\end{array}$ & $\begin{array}{l}2000- \\
2012\end{array}$ & \\
\hline NLD & $\begin{array}{l}1986- \\
2010\end{array}$ & $\begin{array}{l}2001- \\
2011\end{array}$ & $\begin{array}{l}1986- \\
2012\end{array}$ & $\begin{array}{l}1986- \\
2012\end{array}$ & $\begin{array}{l}1986- \\
2010\end{array}$ & $\begin{array}{l}1986- \\
2012\end{array}$ & $\begin{array}{l}1986- \\
2012\end{array}$ & $\begin{array}{l}1986- \\
2010\end{array}$ & $\begin{array}{l}1986- \\
2010\end{array}$ & $\begin{array}{l}1986- \\
2012\end{array}$ & $\begin{array}{l}1986- \\
2012\end{array}$ & $\begin{array}{l}1986- \\
2012\end{array}$ & $\begin{array}{l}1986- \\
2012\end{array}$ & $\begin{array}{l}1986- \\
2012\end{array}$ & $\begin{array}{l}1986- \\
2012\end{array}$ & $\begin{array}{l}1986- \\
2010\end{array}$ \\
\hline NOR & $\begin{array}{l}1995- \\
2011\end{array}$ & $\begin{array}{l}2001- \\
2011\end{array}$ & $\begin{array}{l}1995- \\
2011\end{array}$ & $\begin{array}{l}1995- \\
2011\end{array}$ & $\begin{array}{l}1995- \\
2011\end{array}$ & $\begin{array}{l}1995- \\
2011\end{array}$ & $\begin{array}{l}1995- \\
2011\end{array}$ & $\begin{array}{l}1995- \\
2007\end{array}$ & $\begin{array}{l}1995- \\
2011\end{array}$ & & $\begin{array}{l}1995- \\
2011\end{array}$ & $\begin{array}{l}1995- \\
2011\end{array}$ & $\begin{array}{l}1995- \\
2011\end{array}$ & $\begin{array}{l}1995- \\
2011\end{array}$ & $\begin{array}{l}1995- \\
2011\end{array}$ & $\begin{array}{l}1995- \\
2011\end{array}$ \\
\hline NZL & $\begin{array}{l}1985- \\
2011\end{array}$ & $\begin{array}{l}2005- \\
2011\end{array}$ & $\begin{array}{l}1985- \\
2011\end{array}$ & $\begin{array}{l}1985- \\
2011\end{array}$ & $\begin{array}{l}1985- \\
2011\end{array}$ & $\begin{array}{l}1991- \\
2011\end{array}$ & $\begin{array}{l}1985- \\
2011\end{array}$ & $\begin{array}{l}1985- \\
2007\end{array}$ & $\begin{array}{l}1985- \\
2011\end{array}$ & $\begin{array}{l}1985- \\
2011\end{array}$ & $\begin{array}{l}1985- \\
2011\end{array}$ & $\begin{array}{l}1985- \\
2011\end{array}$ & $\begin{array}{l}1989- \\
2011\end{array}$ & $\begin{array}{l}1985- \\
2011\end{array}$ & $\begin{array}{l}1985- \\
2011\end{array}$ & \\
\hline POL & $\begin{array}{l}2005- \\
2011\end{array}$ & $\begin{array}{l}2004- \\
2012\end{array}$ & $\begin{array}{l}2005- \\
2011\end{array}$ & $\begin{array}{l}2005- \\
2011\end{array}$ & $\begin{array}{l}2005- \\
2011\end{array}$ & $\begin{array}{l}2005- \\
2011\end{array}$ & $\begin{array}{l}2005- \\
2011\end{array}$ & $\begin{array}{l}2005- \\
2009\end{array}$ & $\begin{array}{l}2005- \\
2011\end{array}$ & $\begin{array}{l}2005- \\
2011\end{array}$ & $\begin{array}{l}2005- \\
2011\end{array}$ & $\begin{array}{l}2005- \\
2011\end{array}$ & $\begin{array}{l}2005- \\
2011\end{array}$ & $\begin{array}{l}2005- \\
2011\end{array}$ & $\begin{array}{l}2005- \\
2011\end{array}$ & \\
\hline PRT & $\begin{array}{l}2004- \\
2010\end{array}$ & $\begin{array}{l}2004- \\
2012\end{array}$ & $\begin{array}{l}2004- \\
2012\end{array}$ & $\begin{array}{l}2004- \\
2012\end{array}$ & $\begin{array}{l}2004- \\
2010\end{array}$ & $\begin{array}{l}2004- \\
2012\end{array}$ & $\begin{array}{l}2004- \\
2012\end{array}$ & $\begin{array}{l}2004- \\
2008\end{array}$ & $\begin{array}{l}2004- \\
2010\end{array}$ & $\begin{array}{l}2004- \\
2012\end{array}$ & $\begin{array}{l}2004- \\
2012\end{array}$ & $\begin{array}{l}2004- \\
2010\end{array}$ & $\begin{array}{l}2004- \\
2012\end{array}$ & $\begin{array}{l}2004- \\
2012\end{array}$ & $\begin{array}{l}2004- \\
2012\end{array}$ & \\
\hline SVK & $\begin{array}{l}2004- \\
2010\end{array}$ & $\begin{array}{l}2006- \\
2012\end{array}$ & $\begin{array}{l}2004- \\
2012\end{array}$ & $\begin{array}{l}2004- \\
2012\end{array}$ & $\begin{array}{l}2004- \\
2010\end{array}$ & $\begin{array}{l}2004- \\
2012\end{array}$ & $\begin{array}{l}2004- \\
2012\end{array}$ & $\begin{array}{l}2004- \\
2010\end{array}$ & $\begin{array}{l}2004- \\
2010\end{array}$ & $\begin{array}{l}2004- \\
2012\end{array}$ & $\begin{array}{l}2004- \\
2012\end{array}$ & $\begin{array}{l}2004- \\
2012\end{array}$ & $\begin{array}{l}2004- \\
2012\end{array}$ & $\begin{array}{l}2004- \\
2012\end{array}$ & $\begin{array}{l}2004- \\
2012\end{array}$ & \\
\hline SVN & & $\begin{array}{l}2001- \\
2011\end{array}$ & $\begin{array}{l}2004- \\
2012\end{array}$ & $\begin{array}{l}2004- \\
2012\end{array}$ & $\begin{array}{l}2004- \\
2010\end{array}$ & $\begin{array}{l}2008- \\
2012\end{array}$ & $\begin{array}{l}2004- \\
2010\end{array}$ & $\begin{array}{l}2004- \\
2008\end{array}$ & $\begin{array}{l}2004- \\
2010\end{array}$ & $\begin{array}{l}2006- \\
2012\end{array}$ & $\begin{array}{l}2004- \\
2012\end{array}$ & $\begin{array}{l}2004- \\
2010\end{array}$ & $\begin{array}{l}2004- \\
2012\end{array}$ & $\begin{array}{l}2004- \\
2012\end{array}$ & $\begin{array}{l}2004- \\
2012\end{array}$ & $\begin{array}{l}2004- \\
2010\end{array}$ \\
\hline SWE & $\begin{array}{l}1991- \\
2011\end{array}$ & $\begin{array}{l}2005- \\
2011\end{array}$ & $\begin{array}{l}1991- \\
2011\end{array}$ & $\begin{array}{l}1991- \\
2011\end{array}$ & $\begin{array}{l}1991- \\
2011\end{array}$ & $\begin{array}{l}1991- \\
2011\end{array}$ & $\begin{array}{l}1991- \\
2011\end{array}$ & $\begin{array}{l}1991- \\
2009\end{array}$ & $\begin{array}{l}1991- \\
2011\end{array}$ & & $\begin{array}{l}1991- \\
2011\end{array}$ & $\begin{array}{l}1991- \\
2011\end{array}$ & $\begin{array}{l}1991- \\
2011\end{array}$ & $\begin{array}{l}1991- \\
2011\end{array}$ & $\begin{array}{l}1991- \\
2011\end{array}$ & $\begin{array}{l}1991- \\
2011\end{array}$ \\
\hline TUR & $\begin{array}{l}2005- \\
2011\end{array}$ & $\begin{array}{l}2001- \\
2011\end{array}$ & & & $\begin{array}{l}2005- \\
2011\end{array}$ & $\begin{array}{l}2005- \\
2011\end{array}$ & $\begin{array}{l}2005- \\
2011\end{array}$ & $\begin{array}{l}2005- \\
2005\end{array}$ & & $\begin{array}{l}2005- \\
2011\end{array}$ & $\begin{array}{l}2005- \\
2011\end{array}$ & $\begin{array}{l}2005- \\
2005\end{array}$ & $\begin{array}{l}2005- \\
2011\end{array}$ & $\begin{array}{l}2005- \\
2011\end{array}$ & $\begin{array}{l}2005- \\
2011\end{array}$ & \\
\hline USA & $\begin{array}{l}1995- \\
2011 \\
\end{array}$ & $\begin{array}{l}2002- \\
2012 \\
\end{array}$ & $\begin{array}{l}1995- \\
2011\end{array}$ & $\begin{array}{l}1995- \\
2011 \\
\end{array}$ & $\begin{array}{l}1995- \\
2011\end{array}$ & $\begin{array}{l}1995- \\
2011\end{array}$ & $\begin{array}{l}1995- \\
2011 \\
\end{array}$ & & $\begin{array}{l}1995- \\
2011\end{array}$ & $\begin{array}{l}1995- \\
2011\end{array}$ & $\begin{array}{l}1995- \\
2011 \\
\end{array}$ & $\begin{array}{l}1995- \\
2011\end{array}$ & $\begin{array}{l}1995- \\
2011\end{array}$ & $\begin{array}{l}1995- \\
2011\end{array}$ & $\begin{array}{l}1999- \\
2007\end{array}$ & $\begin{array}{l}1995- \\
2009 \\
\end{array}$ \\
\hline
\end{tabular}

Note: The sample is mostly restricted by availability of household income statistics from the OECD Income Distribution database. See the companion paper (Hermansen et al., 2016) for details. 